UNIVERSIDADE DE SÃO PAULO

FACULDADE DE FILOSOFIA, CIENCIAS E LETRAS

RUI RIBEIRO FRANCO

\title{
Zeólitas dos Basaltos do Brasil Meridional (Gênese e Paragênese)
}


Os Boletins da Faculdade de Filosofia, Ciências e Letras da Universidade de São Paulo, são editados pelos Departamentos das suas diversas secções.

'Toda correspondência deverá ser dirigida para o Departamento respectivo da Faculdade de Filosofia, Ciências e Letras Caixa Postal 8.105, S. Paulo, Brasil.

The "Boletins da Faculdade de Filosofia, Ciências e Letras da Universidade de S. Paulo" are edited by the different departments of the Faculty.

All correspondence should be addressed to the Department concerned, Caixa Postal 8.105, São Paulo, Brasil.

\section{UNIVERSIDADE DE SĀO PAULO \\ Reitor:}

Prof. Dr. Ernesto de Moraes Leme

Diretor da Faculdade de Filosofia, Ciências e Letras:

Prof. Dr. Euripedes Simões de Paula

Secretário:

Dr. Odilon Nogueira de Mattos

\section{DEPARTAMENTO DE MINERALOGIA E PETROGRAFIA}

\section{Professor:}

Dr. Reynaldo Ramos.de Saldanha da Gama

Professor interino:

Dr. Rui Ribeiro Franco

Assistentes:

Dr. William Gerson Rolim de Camargo

Dr. José Moacyr Vianna Coutinho

Auxiliar de ensino:

Lic. ${ }^{\circ}$ João Ernesto de Souza Campos

Estagiários Licenciandos:

Alfredo S. Björnberg

Erancisco K. Takeda

Murillo C. Porto

Rheinholt Ellert 


\begin{abstract}
UNIVERSIDADE DE SÃO PAULO
FACULDADE DE FILOSOFIA, CIÊNCIAS E LETRAS
\end{abstract}

RUI RIBEIRO FRANCO

Zeólitas dos Basaltos do Brasil Meridional (Gênese e Paragênese) 



\title{
Zeólitas dos Basaltos do Brasil Meridional (Gênese e Paragênese)
}

\author{
Com 19 figuras, 9 fotomicrografias e 22 fotografias
}





\section{ZEÓLITAS DOS BASALTOS DO BRASIL MERIDIONAL ( G ên e s e e P a r a g ên e s e) \\ por}

\section{Rui Ribeiro Franco}

Indice sistemático

$\begin{array}{cc}\text { I - Introdução } & 5 \\ \text { II - Trabalhos anteriores } & 6 \\ \text { III - Zeólitas. Considerações gerais e métodos utilizados em } & 9 \\ \text { sua determinação } & 11 \\ \text { IV - Mineralogia descritiva } & 13 \\ \text { A) Zeólitas: analcita, chabazita, thomsonita, ptilolita, } & 15 \\ \text { natrolita, stellerita, heulandita } & \\ \quad \text { Minerais associados: delessita, daphnita, celado- } & \\ \quad \text { nita, quartzo, calcedônia, calcita, girolita, apofi- } & 24 \\ \text { lita, pirita, cobre nativo } & 34 \\ \text { V - Basaltos amigdaloidais } & 35 \\ \text { VII - Diabásios Análises mineralógica e química dzs basaltos e diabá- } & 40 \\ \text { sios do Brasil meridional } & 44 \\ \text { VIII - Gênese das zeólitas e minerais associados } & 49 \\ \text { IX - Paragênese e discussão } & 50 \\ \text { X - Sumário e conclusões } & 50 \\ \text { XI - Agradecimentos } & \end{array}$

\section{A B S T R A C T}

The basalts and diabases which cover an extensive area of the southern States of Brazil are often bearers of varied species of zeolites (analcite, chabazite, thomsonite, ptiloli'e, natrolite, scolecite, mesolite, laumontite, stilbite, stellerite, and heulandite) and as many other related minerals (delessite, daphnite, celadonite, quartz, chalcedony, calcite, gyroli'e, apophyllite, pyrite, and native copper). In the basalts the above mentioned minerals occur in cavities of varied forms, while in the diabases they are located in the zones of shearing. They originated, mainly, from final residual solutions of the basaltic magma itself, which were trapped inside the cavities or in the fractures of the diabases. The order of deposi'ion of the minerals in the amygdalae and fractures is no: haphazard. On the contrary, there exists a definite sequence, always repeated, in the material examined, no matter what its source. The minerals of the chlorite group and those of the silica group are always the first to be formed. They are followed by the zeolites, then apophyllite, calcite and finally the sulphides. Among the zeolites there is also a certain order of depositicn. The heulandite precedes the rest. It is followed by stilbite, which in i's turn precedes chabazite. In the zones of shearing of the diabases calcite seems to go contrary to the above order, preceding the deposition of zcolites. There are zones of amygdaloidal basalts in which the cavi- 
ties are filled by only one kind of mineral - sometimes only minerals of the silica group, o'her times only analcite, mesolite, or chabazite. Phenomena of pseudomorphic substitutions among the minerals which fill the cavities and fractures of the basalts and diabases are not rare. The inclusions of sandstones and even sands of the Botucatu formation in the basaltic lava flows did not at all influence the lava which reached the surface. There are no signs of thermal metamorphism between the oldest amygdaloidal basalts and lavas and the most recent diabasic intrusions. The absence of numerous species of zeolites seems to be connected wi'h the lack of certain elements in the lava and basalts and also the non-existence of differentiated petrographic types. In the amygdaloidal basalts, as well as in the homogenous ones and in the other types, as well as in the diabases there are found neither pyrogenic zeoli'es nor phenomena of analcitization.

\section{I - Introdução}

O presente trabalho foi organizado com o objetivo de sistematizar nossos conhecimentos sobre o grupo de minerais denominado zeólitas, encontradas nos derrames basálticos e intrusivas diabásicas do Brasil meridicnal, bem como estabelecer as relações genéticas e paragenéticas existentes entre elas e as rochas matrizes. Embora sejam apresentados os resultados de estudos sobre as zeólitas de numerosas localidades diferentes, como se vê no mapa, Fig. 1, há diversas outras ocorrências de interesse que, com certeza, serão estudadas posteriormente. Os basaltos amigdaloidais ocupam uma área muito extensa e grande parte dela ainda está coberta de sedimentos ou densa vegetação. Isso dificulta sobremaneira a localização de novas ocorrências. Muitas vezes o estudo das zeólitas foi facilitado pelo encontro, "in situ", de amígdalas soltas provenientes dos basaltos que as continham, quando destruidos pela meteorização. Grande parte do material estudado foi coletado pelo autor e se encontra hoje ao lado das coleções de zeólitas do Departamento. Entre estas destacam-se as coleções Araujo Ferraz e José Giorgi Junior, a primeira adquirida e a segunda doada, ambas incorporadas ao patrimônio da Faculdade de Filosofia, Ciências e Letras da Universidade de São Paulo. Outra parte foi cedida por colegas. Obtiveram-se muitas informações utilizando-se as zeólitas da coleção do museu do Instituto Geográfico e Geológico de São Paulo, onde ainda se encontram exemplares estudados e coletados por Hussak (1890). Ainda de especial interêsse para o trabalho foram as amostras de zeólitas obtidas das coleções do Departamento Nacional da Produção Mineral, Ministério da Agricultura, Rio de Janeiro; do Museu Nacional, Rio de Janeiro; da Escola Politécnica da Universidade de São Paulo; da Escola Superior de Agricultura Luiz de Queiroz, Piracicaba, São Paulo; da Universidade de Roma, Itália, por intermédio do prof. dr. Ettore Onorato e, mais particularmente, do British Museum of Natural History, Londres, Inglaterra, por gentileza do dr. Max H. Hey, curador-assistente desse estabelecimento. Para maior precisão na determinação das zeólitas e minerais associados (minerais que ocorrem juntamente com as zeólitas e que perten- 


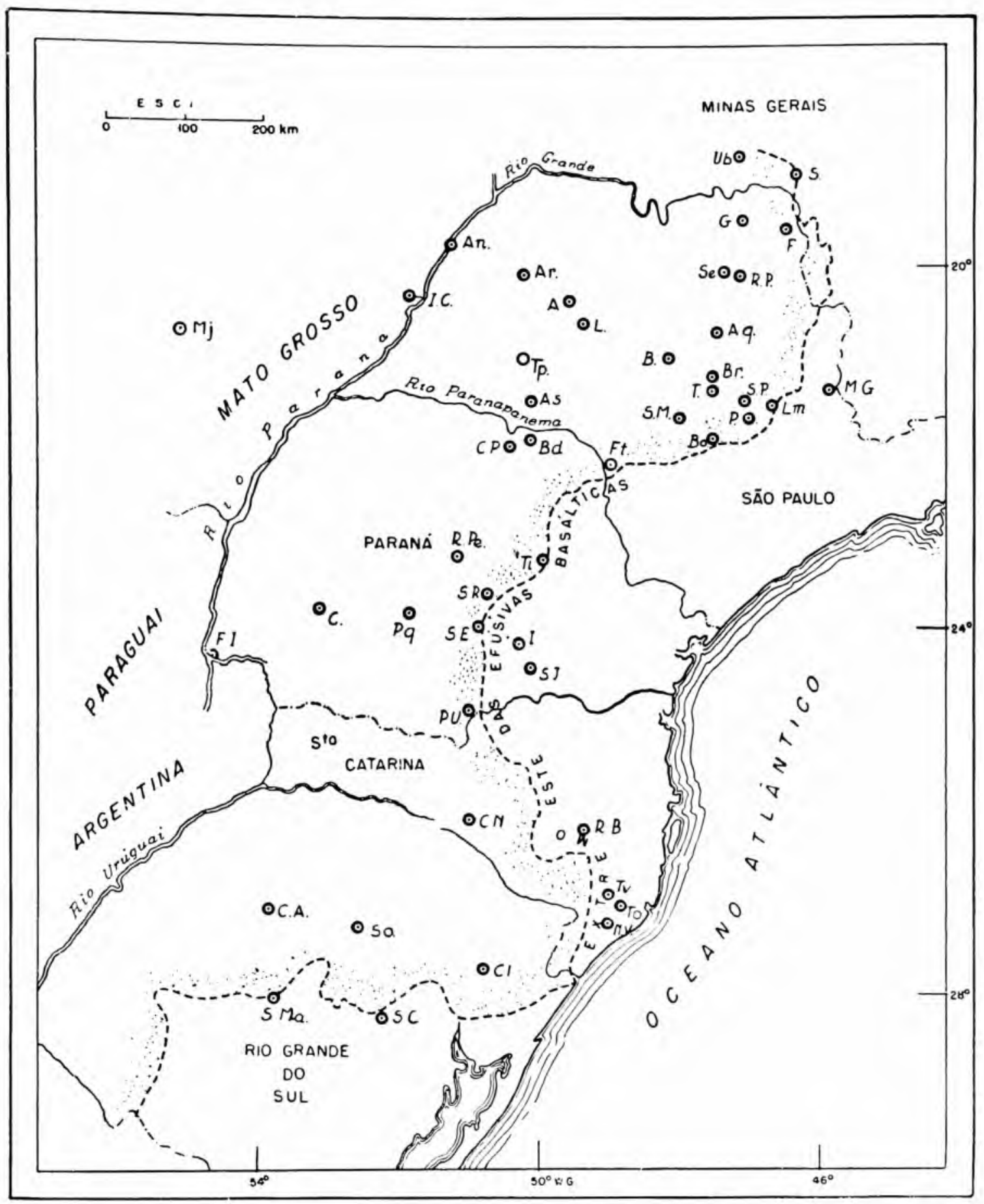

Fig. 1 - Ocorrências de efusivas basálticas e sills de diabásio contendo zeólitas e minerais associados.
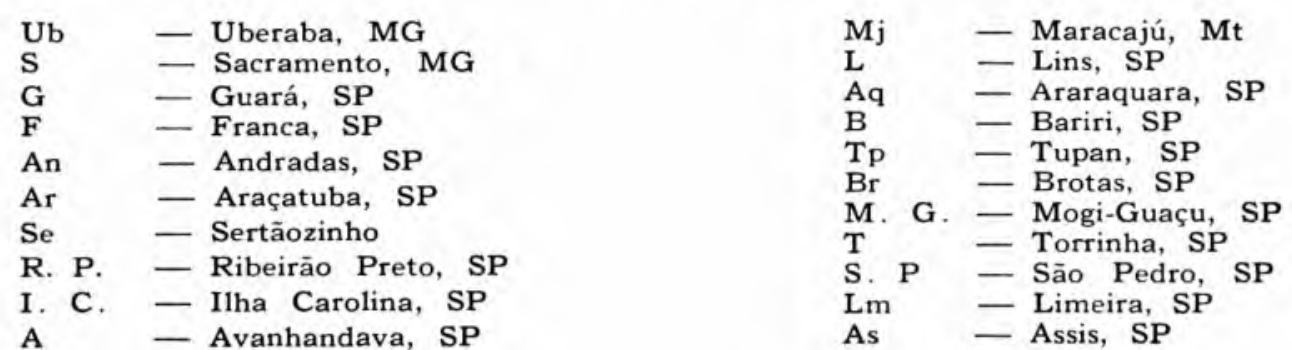

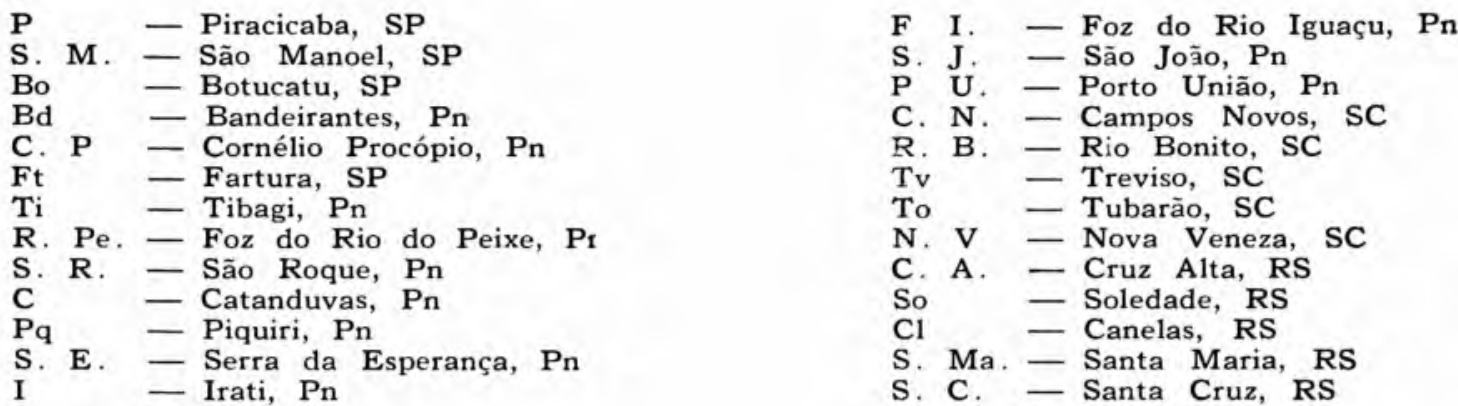

cem a grupos diferentes), que se encontram nos basaltos amigdaloidais do Brasil meridional e em algumas formas intrusivas de diabásio utilizamos as coleções-padrão doadas pelo National Museum (Smithsonian Institution), Washington, D.C., U.S.A., obtida por intermédio do dr. William D. Johnston, Jr., chefe da secção de Geologia Estrangeira e do Alaska do U. S. Geological Survey e a do British Museum, já referida.

Algumas das análises apresentadas na parte referente aos minerais de preenchimento foram executadas pelo Instituto de Pesquisas Tecnológicas, da Universidade de São Paulo.

No presente trabalho, não foram versados certos aspectos que fazem das zeólitas um dos grupos de minerais extremamente interessantes. Assim, deixou-se de lado o estudo das curvas contínuas de desidratação; o das propriedades piro- e piezoelétricas; os problemas referentes à troca de cationios (usualmente $\mathrm{Na}+\mathrm{e} \mathrm{Ca}++$ ) das zeólitas por metais ativadores fluorescentes $\left(\mathrm{Mn}^{++}, \mathrm{Pb}^{++}, \mathrm{Cu}^{++}, \mathrm{Ag}^{+}\right)$; a questão das "zeólitas" artificiais; o estudo das substâncias ultra-marinhas (lazurita, noseana, haüyna e sodalita) e das permutitas, assuntos intimamente ligados às zeólitas, porque visamos mais diretamente aos aspectos genético e paragenético do problema. Também não nos detivemos no estudo das amígdalas preenchidas exclusivamente de quartzo ou quartzo e calcedônea, porque FreYberG $(1927,1930)$ deles já se ocupou exaustivamente. Embora FREYBERG se tenha preocupado sòmente com o estudo descritivo e genético dos minerais da família da sílica, que ocorrem nas amígdalas dos basaltos, não deixa de ser estranho que não houvesse mencionado em qualquer dos seus dois trabalhos, minerais do grupo das zeólitas, comuns nos basaltos amigdaloidais da serra Geral. Como minerais das amígdalas, cita sòmente as ágatas, quartzo, calcita, uma substância verde (clorita) e um grande cristal de gipso encontrado em uma drusa pertencente à coleção Henning, em Santa Cruz, Rio Grande do Sul. Infelizmente FREYBERG não conseguiu estabelecer a origem deste cristal, o que possìvelmente traria algum elemento novo à análise paragenética. Entretanto, concordamos com êle quando diz que são raros os cristais de pirita e calcopirita nas amígdalas, os quais poderiam ter dado origem ao ácido sulfúrico necessário à formação do gipso. Em nosso estudo das amígdalas, fendas e vênulas de muitos basaltos amigdaloidais do Brasil meridional e do arenito triássico que se encontra em contacto com os derrames, sòmente duas vezes pudemos verificar a presença de cristais de pirita juntamente com zeólitas e outros minerais associados. Tais asso- 
ciações ocorrem em Mogi-Guaçu, São Paulo, Fig. 17, e na pedreira de Tatú, proximidades de Limeira, São Paulo.

A falta de qualquer referência a zeólitas, por parte de FREYBERG, indica, talvez, ter êle visitado uma única região, onde sòmente eram encontradas amígdalas preenchidas exclusivamente por minerais da família da sílica e calcita. Outra hipótese a ser invocada seria o da substituição dos minerais do grupo das zeólitas pela sílica de formação posterior, como acontece $c=m$ a calci $a$ que muitas vezes é total ou parcialmente substituída, deixando, entretanto, em muitos casos, sua forma antiga.

Os casos de pseudomorfose estudados por ENGLERT (1925), em nota mineralógico-petrográfica sobre alguns basaltos amigdaloidais do Estado do Rio Grande do Sul e que também menciona zeólitas como minerais de formação secundária, embora não os mencione individualmente, são bem típicos. Os exemplos por êle citados são pseudomorfoses de calcedônia e óxidos de ferro scbre calcita.

Dedicamos algumas páginas ao estudo cristalográficu-físico das várias espécies de zeólitas e dos minerais associados, porque por êle pudemos tirar conclusĩes de ordem paragenética.

\section{II - Trabalhos anteriores}

Oliveira (1889) cita em seu trabalho numerosas ocorrências de basaltos amigdaloidais, mencionando apenas os seguintes minerais das drusas, geodos e amígdalas: quartzo, quartzo ametista, ágata, calcita e stilbita, sem ccntudo tratar de sua genêse ou paragênese.

O trabalho de Hussak (1890) constitui uma das principais fontes sobre as zeólitas do Brasil meridional. Estudando o material que ocorre nas serras de Botucatú e Brotas e na pedreira de diabásio de Mogi-Guaçu, São Paulo, e serra Tubarãc, Santa Catarina, descreve Hussak CS seguintes minerais encontrados nas amígdalas: calcita, calcedônia, cobre nativo, um mineral cloritoso amorfo, heulandita (stilbita), mesolita, laumontita, girolita, apofilita, desmina e scolecita. Revimos e classificamos alguns dos minerais descritos por HussaK $(1890,1906)$.

LEME (1914), estudando cortes de estrada de ferro no Estado do Paraná, descreveu notável ocorrência de zeólitas na foz do rio do Peixe, afluente do Ivai. As zeólitas descritas (stilbita, heulandita, mesolita, apofilita (?), laumontita e chabazita) acham-se em cavidades e geodos de um basalto de granulação fina, alterado, rico de limonita e delessita. Como Hussak (1890), LEME procurou traçar a ordem de sucessão das diversas zeólitas. Achou que a ordem não é rigida, pelo menos para todas as espécies. Assim, verificou que a heulandita e a stilbita são as primeiras a se formarem, a stilbita precedendo a heulandita. A laumontita parece preceder as duas mencionadas. O que se lhe afigura incontestável é a formação da apofilita depois de todos os outros minerais das amígdalas, com exceção da mesolita, que apresenta suas agulhas im- 
plantadas sobre todas as outras. $\mathrm{O}$ autor, que estudou o mesmo material, ainda existente nas coleções de zeólitas do Museu Nacional, Rio de Janeiro, está parcialmente de acordo com Leme. Aliás, quando se comparar a paragênese das zeólitas do rio do Peixe com a paragênese das zeólitas de outras regiōes do Brasil meridional, o que faremos mais adiante, ver-se-á que elas são muito semelhantes.

Guimarães (1933), em sua monografia sôbre a província magmática do Brasil meridional, estuda os basaltitos amigdaloidais (meláfiros) e transcreve a descrição contida no trabalho de HuSSAK (1890) referente aos minerais das amigdalas. Acrescenta, aos minerais mencionados, ágata, quartzo, girolita, apofilita, laumontita, analcita, viridita, clorita e siderita, embora não trate deles.

WALTHER (1938), também trata das eruptivas basálticas que ocorrem no Brasil e cita os tipos amigdaloidais. Embora analise pormenorizadamente os aspectos petrográficos e geológicos dos derrames, comparando-os com os que ocorrem na África e Argentina, não trata dos minerais das amígdalas.

MAACK (1939), quando descreve o planalto escarpado de Santa Catarina cita vários derrames basálticos amigdaloidais e seus minerais de preenchimento, fazendo menção ao quartzo hialino, ametitsta, calcedônia, ágata e zeólitas (heulandita).

As análises químicas feitas pelo analista FLORENCE foram tiradas do Boletim n. 24 do Instituto Geográfico e Geológico de São Paulo, páginas 49-50, 1939.

Franco (1939) estudando algumas amígdalas dos derrames basálticos da serra de Botucatú, São Paulo, descreveu sòmente os cristais de calcita escalencédrica não se detendo, naquela ocasião, com as zeólitas que a acompanhavam.

Almeida (no preio), em tese apresentada ao $2 .^{\circ}$ Congresso PanAmericano de Engenharia de Minas e Geologia, estuda os basaltos do planalto de Maracaju, sul de Mato Grosso, citando os seguintes minerais de preenchimento das amígdalas: calcedônia, ágata, quartzo, calcita, minerais cloríticos (delessita, clorofeita), stilbita, chabazita e outras zeólitas, cobre nativo e malaquita.

Embora sejam poucos os trabalhos que tratam das zeólitas encontradas nos basaltos amigdaloidais do Brasil meridional, ou a elas fazem referência, existem numerosos trabalhos de interêsse petrográfico e geológico sôbre aqueles tipos de basaltos. O mais recente de todos, de autoria de LEINZ (1949), constitui a mais completa fonte de informações sobre a geologia e a petrografia da área ocupada pelos derrames basálticos. Assim, trata com pormenores, do vulcanismo, da tectônica e da ascenção do magma basáltico, abcrdando os problemas relativos às formas efusivas, às intrusivas (diques e sills), à petrologia das efusivas, dos movimentos anteriores e simultâneos ao vulcanismo e post-vulcânicos. Descrevendo as partes superiores dos basaltos da região Três Forquilhas-Tainhas, Estado do Rio Grande do Sul, menciona a existência de diá- 
clases horizontais seguidas por uma zona de cinco a dez metros de espessura, rica de amígdalas normalmente elíticas, com o eixo menor no sentido vertical, ora vazias, ora preenchidas por zeólitas. LEINZ, contudo, não as menciona individualmente. Estudando as variações texturais características para uma corrida de lava localiza as duas partes fundamentais - a zona vítrea e a faixa "melafírica" - a primeira na soleira do derrame, onde o resfriamento se faz ràpidamente devido ao contacto ccm o embasamento e a seguncla na parte superior do derrame, zona em que se dá o enriquecimento de gases sob alta pressão, e resfriamento também rápido dado que o material em estado de fusão se solidifica em contato com a atmosfera. É na faixa melafírica de LEINZ que se encontram as amígdalas ricas de minerais secundários.

\section{III - Zeólitas - Considerações gerais e métodos utilizados em sua determinação}

Embora as zeólitas formem um grupo de minerais de considerável interêsse, muitos dos seus caracteres ainda permanecem obscuros. A investigação ótica, a que mais de perto nos interessou, exigiu trabalho extremamente cuidadoso, dadas as variações das propriedades óticas dentro de uma mesma espécie mineral. Não raro tivemos de usar métodos diferentes na determinação dos valores óticos mais característicos, pois do contrário poderíamos incorrer em falta. Zeólitas já classificadas por Autores que nos precederam tiveram de ser descritas novamente, porque nem sempre houve concordância entre os valores determinados. Em muitos casos, principalmente quando se tratou das variedades de zeólitas prismáticas, a propria determinação do sistema cristalino foi sobremaneira difícil. Os intercrescimentos de duas ou mais espécies, intercrescimentos que foram tomados por muitos pesquisadores como um único mineral, foram estudados cuidadosamente em lâminas delgadas. Caso assim ocorre com as amostras de zeólitas fibro-radiadas da região de Torrinha, São Paulo. O material que aí ocorre em enormes massas no interior do basalto rico de amígdalas e vênulas irregulares é um intercrescimento de mesolita, natrolita e thomsonita, Fig. 4. As massas fibro-radiadas são constituidas na parte mais interna por mesolita e natrolita, enquanto na mais externa do agregado fibroso aparecem os cristais ripiformes de thomsonita. Outro intercrescimento é o encontrado em material zeolítico de Mogi-Guaçu, São Paulo, onde as amostras exibem asscciação íntima entre girolita, laumontita, apofilita e calcita. Os cristais de laumontita ocorrem irregularmente distribuidos entre as lâminas da girolita e esta, muitas vêzes, está englobada pela apofilita, Fig. 17 Nesses dois casos parece não haver dúvida no estabelecimento da ordem de formação ou precipitação das várias espécies. No primeiro caso, a massa fibro-radiada se inicia pela sucessão alternada de mesolita e natrolita, enquanto a thomsonita somente se forma no final da precipitação, nas partes periféricas. No segundo exemplo o primeiro mineral a se formar é a calcita, o segundo a laumontita, vindo a seguir a giroli- 
ta e por último a apofilita. Nem sempie, contudo, a determinação constituiu problema difícil, pois algumas vezes tivemos a oportunidade de encontrar grandes áreas de basalto constituidas de um só tipo de amígdalas, preenchidas também por uma só espécie de zeólita. Casos como êsse, onde se nota visível homogeneidade na rocha amigdaloidal, foram encontrados na barragem da Emprêsa de Eletricidade Vale Paranapanema S.A., São Paulo, onde amígdalas são preenchidas sòmente por heulandita ou stilbita. Em Lins, São Paulo, em recente excavação, atravessou-se um der̃ame amigdaloidal uniforme, onde as cavidades regulares e esféricas são preenchidas exclusivamente por analcitas de hábito icositetraédico, Fig. 18. Amígdalas preenchidas totalmente por chabazita - zeólita não muito comum em nossos basaltos amigdaloidais foram encontradas no município de Canela, Rio Grande do Sul.

Situação idêntica encontramos no trabalho de Millosevich (1908), quando descreve gecdos preenchidos sòmente por chabazita, ou mesolita ou, ainda, stilbita.

A determinação das zeólitas e minerais associados foi feita utilizando-se os seguintes métodos:

a) cristalográficos - O hábito cristalino possibilitou-nos a separação das zeólitas em grupos, antes de utilizarmos os meios físicos e químicos na sua identificação. Tanto quanto foi possivel, determinamos os ângulos interfaciais normais (ângulos entre as normais às faces), para a identificação das formas presentes nos cristais. Especial atenção foi dada ao estudo dos geminadcs, porque as formas de geminação constituem meios seguros de identificação das várias espécies. Ainda, sob o ponto de vista morfológico, foi de grande importância o estudo do estado de agregação das diferentes espécies, as imperfeições várias e as inclusões. As próprias relações genéticas e principalmente as paragenéticas foram de grande valor no estudo determinativo.

b) físicos - Infelizmente quase não pudemos nos valer do peso específico para a identificação das zeólitas, dada a interpenetração das várias formas aciculares. Sòmente as espécies isoladas e puras foram utilizadas para a determinação dessa propriedade. Clivagem e dureza constituiram elementos de identificação. Contudo, os dados óticos foram os que mais serviram à identificação das numerosas espécies minerais. Levou-se muito em consideração a determinação dos índices de refração, feita por meio do método de imersão, utilizando-se uma bateria de líquidos de índices de refração conhecidos, preparada no U. S. Geological Survey e outra de procedência alemã. Em alguns casos, utilizamos a platina universal de Federov para a determinação do ângulo dos eixos óticos. As determinações dos índices de refração dos minerais foram feitas à temperatura aproximada de $18^{\circ} \mathrm{C}$. Nossos exemplares não mostraram qualquer reação de fosforescência ou fluorescência.

c) químicos - Muitos testes químicos foram feitos pelo autor, principalmente quando se tratou de assinalar a presença de alguns elementos raros ( $\mathrm{Ba}, \mathrm{Sr}$ ). Análises químicas completas foram executadas pelo Instituto de Pesquisas Tecnológicas da Universidade de São Paulo 
Os resultados obtidos dos exames foram plenamente satisfatórios para a identificação de todos os minerais mencionados nesta tese. As determinações dos índices de refração pelo método de imersão foram feitas admitindo-se um êrro de $\perp 0,002$.

Na descrição das várias espécies de zeólitas adotámos a ordem seguida por WINCHELL, (1951).

\section{IV - Mineralogia Descritiva}

As zeólitas são silicatos de alumínio, metais alcalinos ou alcalinos terrosos e contêm, ainda, água, que pode ser retirada por processos diversos, sem que haja destruição do cristal.

Notável característica é a relação molecular $\mathrm{Al}_{\Perp 2} \mathrm{O}_{33}$ : ( $\mathrm{Ca}, \mathrm{Sr}, \mathrm{Ba}, \mathrm{Na}_{2}$, $\mathbf{K}_{\text {2. })} \mathrm{O}$, sempre igual à unidade. Isso obrigou-nos a considerar a apofilita à parte, pois ela possui porcentagem insignificante de alumina, chegando mesmo a faltar totalmente.

Embora muito semelhante quanto à composição química as zeólitas apresentam-se na natureza cristalizadas com simetrias diversas e hábitos os mais variados. Assim, são monométricas a analcita e a faujasita; tetragonal a ashcroftina; rcmboédricas a chabazita e gmelinita; rộmbicas as variedades natrolita, thomsonita e ptilolita; heulandita, stilbita e scolecita são monoclínicas, enquanto mesolita é, provàvelmente, triclínica. As propriedades óticas variam muito de zeólita para zeólita. Contudo, na sua grande maioria, possuem índices de refração baixos e birrefrigência fraca, podendo esta última ser igual a zero, como soe acontecer com as mesolitas das regiões paulistas de Sertãozinho, São Pedro e Torrinha.

Com exceção de algumas heulanditas encontradas na serra de Botucatu, São Paulo, stilbitas de Torrinha, São Paulo e analcitas da região de Piqueri, Paraná, que se apresentam ligeiramente coloridas (róseas), a grande maioria das zeólitas estudadas são brancas ou incolores e mais raramente cinzentas. Em alguns casos pudemos verificar que a coloração de certas variedades de zeólitas se devia à presença de impurezas de diminutas dimensões. Explica-se por essa forma a coloração escura das heulanditas que preenchem as amígdalas do basalto que ocorre a-cerca-de 38 quilómetros de Assis, São Paulo, na Emprêsa de Eletricidade Vale do Paranapanema S. A., isto é, por incluirem numerosas formações globulares de daphnita. Lâminas sub-microscópicas de hematita são as impurezas que emprestam a certas variedades a coloração rósea.

As zeólitas são consideradas geralmente como minerais secundários, isto é, originadas a partir de outros que se alteram. Mesmo assim elas podem se alterar ainda a ponto de perder totalmente sua individualidade. Em muitos casos a alteração conduz à formação de caulinita, outras vezes de calcita e não muito raramente de uma substância isótropa, de difícil reconhecimento. 
Alterações como as mencionadas foram observadas com as grandes massas de mesolita fibro-radiada da serra de Botucatu e de Sertãozinho, São Paulo. A alteração vai a ponto de destruir totalmente a forma primitiva dos cristais. Curiosa alteração é a que se passa com os cristais prismáticos de laumonita, que ocorrem nas zonas de cizalhamento do diabásio da pedreira situada defronte à estação da Cia Mogina de Estrada de Ferro, Mogi-Guaçu, São Paulo, que se desfazem inteiramente sob a forma de pó branco. Este, examinado ao microscópio, mostrou tratar-se da caporcianita. A mesma alteração encontramos nas amostras de laumontita de outras ocorrências como, por exemplo, Torrinha, São Paulo.

Na serra de São Pedro, São Paulo, nos derrames basálticos amigdaloidais, encontram-se comumente amígdalas ricas de cristais de heulandita parcialmente alterada e reduzida a pó impalpável. $\mathrm{Na}$ mesma região, são comuns amígdalas preenchidas por material como cera, mole, de coloração variável, semelhante a sabão, que apresenta todos os característicos da pinguita e que, provàvelmente, é outro produto de alteração das zeólitas.

Em todos os basaltos amigdaloidais estudados pelo autor jamais foi verificada a presença de zeólitas pirogenéticas. Nem mesmo a analcita ocorre como mineral primário. Nos basaltos de Lins, São Paulo, onde as amígdalas são preenchidas exclusivamente por cristais de analcita, estes são nìtidamente secundários e bem cristalizados. Analcita, natrolita e apofilita compactas, aparentemente produtos finais da solidificação de magmas fonolíticos, foram descritas por $\mathrm{HIBSCH}$ (1921) Lyons, (1944) e PELIKAN, (1906) descrevem, também, analcita de origem magmática.

Examinando-se cuidadosamente ao microscópio, as paredes dessas amígdalas não se nota sinal algum de substituição dos feldspatos do basalto pelo analcita, fenômeno semelhante à albitização e conhecido na literatura por analcitização.

Aliás, os trabalhos supramencionados sôbre o magma basáltico do Brasil meridional não mencionam a presença da analcita entre os minerais pirogenéticos.

Fato interessante para o qual desejamos pedir a atenção e que será examinado detidamente quando tratarmos da genêse e paragênese das zeólitas é a ausência, em todos os derrames de basaltos amigdaloidais do Brasil meridional, de numerosas espécies de zeólitas, comuns em outras regiões do globo. Assim, por exemplo, jamais foram encontradas as variedades faujasita, gmelinita, ashcroftina, levynita, arduinita, gonnardita, erionita, ferrierita, edingtonita, gismondita, phillispsita, harmotomo e brewsterita.

As variedades encontradas até hoje, analisadas física e quìmicamente pelo autor e outros pesquisadores que o precederam, são as seguintes: analcita, chabazita, thomsonita, ptilolita, natrolita, scolecita, mesolita, laumontita, stilbita, stellerita e heulandita. 
Além das zeólitas encontradas ocorrem, nas amígdalas, diversos outros minerais, tais como: delessita, daphnita, hullita, quartzo, calcedônia, ágata, calcita, girolita, apofilita e pirita, cobre metálico ou carbonatos dêsse metal. Há na literatura várias notícias sobre a existência de cobre e seus carbonatos em intima associação com os minerais das amígdalas dos basaltos. Segundo Hussak, (1889), cobre nativo é encontrado com frequência nos Estados meridionais do Brasil. BAKER (1923), em seu estudo sobre os basaltos vesiculares e cavernosos da bacia do Paraná menciona também cobre nativo entre quartzo, ágata, calcedônia, calcita, zeólitas, minerais de cobre e silicatos verdes de ferro. Com referência a êsse metal julgamos interessante discutir alguns dados apresentados por Plinio DE LIMA em comunicação verbal à Sociedade Brasileira de Geologia, no ano de 1948. Segundo êsse pesquisador, as ocorrências de cobre do planalto paranaense foram visitadas no século passado por diversos engenheiros, sendo desde então sabida a sua pequena importância. Em 1908, Euzebio DE Oliveira visitou as cabeceiras do rio do Cobre, concluindo também pela inexistência, ai, de jazidas de minério desse metal. Frequentemente, os supostos minerais cupríferos do planalto paranaense e de muitas outras regiões estudadas pelo autor nada mais são que hidrossilicatos de ferro, de côr verde (delessita, celadonita, daphnita) ou ainda heulandita de coloração vermelha, muito comum no planalto e na serra de Botucatu. $O$ planalto visitado por Plinio DE Lima atinge a altitude de $1.162 \mathrm{~m}$, na serra da Esperança, embora exista um ponto a $1.235 \mathrm{~m}$. Os derrames basálticos mostram declividade de $2,6 \mathrm{~m} / \mathrm{km}$ até a foz do rio Iguaçu e espessura de-cêrca-de $570 \mathrm{~m}$ na direção NNE. Na região amigdaloidal de Goiaxim, Paraná, foram encontradas pequenas palhetas de cobre, idênticas às presentes nos basaltos de Guarapuava, Paraná e de Novo Horizonte, São Paulo, estudadas pelo autor. Análises espectrais de basaltos do planalto paranaense denunciaram a presença dos elementos seguintes: $\mathrm{Cu}$, $\mathrm{Zn}$, Sn e Va. De 16 amostras analisadas, que denunciaram a presença de cobre, sòmente 3 indicaram mais de $0,05 \%$ de $\mathrm{Cu}$.

LEINZ, (1941) refere-se também a pequenas amostras de cobre (algumas até de meio quilo) encontradas na região trapeana do Rio Grande do Sul, nos municípios de Triunfo, Irai, Santo Ângelo, Soledade e Santa Rosa. Em Santo Ângelo, o cobre nativo ocorre sob a forma de pepitas, normalmente de algumas gramas. Nas faixas amigdaloidais ocorre concentrado em manchas, indicando, provàvelmente, caminho das soluções hidrotermais. Nos basaltos de Vila Guaramano, Município de São Luiz Gonzaga, LEINZ encontrou também pedaços de cobre disseminados na rocha.

\section{A - Zeólitas}

A nalcita - Apresenta-se muito bem cristalizada, sempre sob a forma icositetraédrica, Fig. 18. Exibe ao microscópio, quando em lâ- 
minas delgadas, complexos geminados de penetração e não raro, inumeras inclusões. Cristais bem desenvolvidos ocorrem em um basalto altamente poroso encontrado em uma perfuração na cidade de Lins, São Paulo. Exemplares há que mostram estrutura concêntrica. O pêso específico, obtido em cristais microscòpicamente puros, foi 2,27. O índice de refração, determinado em amostras isentas de anomalias óticas, é 1,486 Comum é o fato de analcitas exibirem nítida birrefringência $(0,002)$, dando mesmo, ao microscópio, figuras biaxiais negativas e algumas vezes uniaxiais, conforme as observadas por STEWART (1941).

Chabazit a - Variedade não muito comum entre as zeólitas do Brasil meridional. Além de cristais simples, exibe frequentemente geminação por penetração segundo $\{0001\}$, Fig. 14 . O único hábito encontrado foi o romboédrico. Os numerosos cristais estudados mostram grande variação no comportamento ótico, inclusive variação na posição do plano dos eixos óticos. Alguns exemplares eram uniaxiais e outros biaxiais. O próprio sinal ótico não é fixo, variando entre negativo e positivo.

O pêso específico médio determinado é 2,11. Amostras da região de Canelas, Rio Grande do Sul, de birrefringência muito baixa $(0,002)$, mostraram os seguintes índices de refração: $\mathrm{n} \alpha=1,485, \mathrm{n} \beta=1,486$, $\mathrm{n} \gamma=1,487$.

Th o m s o n it a - Essa zeólita, relativamente rara nas amostras estudadas, foi encontrada poucas vezes. Uma delas foi nas partes superiores das massas fibro-radiadas de mesolita de Sertãozinho, São Paulo. Foi determinada com relativa dificuldade, dada a pequena quantidade de material disponível.

Ptilolita - Zeólita muito comum na região dos basaltos amigdaloidais onde se situa a usina elétrica de Emprêsa de Eletricidade Vale do Paranapanema S. A., proximidade de Assis, São Paulo. Forma no interior das amígdalas belíssimos tufos, Fig. 15. São extremamente delicadas e muitas vezes assemelham-se a algodão. Mostra característicos de ser rômbica e os seguintes índices de refração $\mathrm{n} \alpha=1,475, \mathrm{n} \beta=1,478$, $n \gamma=1,479$. Dada a impossibilidade de separação suficiente de material foi impossível determinar-se o pêso específico e obter-se análise química.

Natrolita - Ocorre a natrolita quase sempre em associação com e mesolita. Contudo, fácil foi a determinação de seus índices de refração $\mathrm{n} \alpha=1,480, \mathrm{n} \beta=1,482, \mathrm{n} \gamma=1,490$. Os cristais são sempre fibro-prismáticos. Amostras características ocorrem em São Pedro, São Paulo.

Scolecita - Zeólita muito rara nos basaltos amigdaloidais estudados. Apresenta-se em agregados fasciculo-radiados, compactos e de coloração ligeiramente rósea. Material característico é o da serra de Tubarão, Santa Catarina, estudado por Hussak (1890). O autor teve 
a oportunidade de conseguir parte do material estudado por HUSSAK e completar alguns dados que faltavam. Assim, foi possivel determinarse os três índices $\mathrm{n} \alpha=1,512, \mathrm{n} \beta=1,518$ e $\mathrm{n} \%=1,519$ e o ângulo dos eixos óticos, (-) $2 \mathrm{~V}= \pm 36^{\circ}$. A dispersão $t<v$ é distinta. As seções normais ao comprimento dos cristais mostram que a scolecita tem contôrno quadrático (ângulo entre as faces aproximadamente $90^{\circ}$ ), muito semelhante ao encontrado para as mesolitas da Fazenda Palmital, Sertãozinho, São Paulo. Parece-nos não haver dúvidas quanto à sua simetria monoclínica. Esse mineral jamais apresentou-se sob a forma de cristais simples. O pêso específico encontrado é 2,27. Scolecita ligeiramente alterada ocorre também nos basaltos amigdaloidais encontrados entre o planalto de Campos Novos e o vale do rio Canoas, Santa Catarina. Os índices de refração da scolecita dessa região são pràticamente os mesmos determinados para a da serra do Tubarão. A scolecita da serra do Tubarão exibe a estriação peniforme sobre (010). Para essa zeólita a análise química feita por HUSSAK acusou o resultado seguinte:

$$
\begin{aligned}
\mathrm{SiO}_{2} & =45,96 \% \\
\mathrm{Al}_{2} \mathrm{O}_{3} & =26,03 \% \\
\mathrm{CaO} & =13,53 \% \\
\mathrm{H}_{2} \mathrm{O} & =\frac{13,67 \%}{99,19 \%}
\end{aligned}
$$

M e s olita - Embora não tão comum como as heulanditas e stilbitas, as mesolitas ocorrem em diversos lugares, principalmente em São Paulo, na serra de Botucatu, Sertãozinho e Torrinha. Apresentam-se como agregados fibrosos (prismáticos) e disposição radial, Figs. 2 e 3. A determinação precisa dessa zeólita, para não confundí-la com as agulhas de natrolita ou scolecita, não apresentou séria dificuldade porque foi possível obter-se algumas secções orientadas, inclusive normais ao comprimento dos cristais aciculares. HUSSAK (1890), estudando a mesolita da serra de Botucatu, descreve a presença de $\{111\}$, "pirâmide" muito obtusa, às vezes combinada com a base. $O$ autor não encontrou essas mesmas formas para a mesolita de Sertãozinho, São Paulo. Os cristais exibem extinção reta (pode ser aparentemente inclinada para os cristais que não estejam perfeitamente paralelos à lamina), os eixos óticos ocupando uma posição aproximadamente normal às faces de prisma. Todos os cristais estudados òticamente mostram-se invariàvelmente geminados e com características monoclínicas, Fig. 4. A birref ingência é muito baixa (lâminas delgadas são pràticamente isótropas), o índice de refração $(\beta)$ sendo igual a 1,505 . Infelizmente não pudemos determinar o pêso específico, dada a interpenetração da mesolita com outros minerais. Característica para as mesolitas estudadas, quando são observadas lâminas perpendiculares ao alongamento, é a divisão do cristal em setores, que não se extinguem simultâneamente Fig. 4. Os cristais de mesolita quando deitados sobre uma face de prisma mostram com certa nitidez 
a linha do plano de geminação. O plano dos eixos óticos determinado é perpendicular ao alongamento, jazendo a bissetriz positiva no ângulo obtuso do prisma. Essa observação, feita não sòmente nas mesolitas da serra de Botucatú, mas também nas de Sertãozinho e Torrinha, está em desacordo com a orientação estabelecida por Hussak. Aliás, foi devido a essa orientação, clivagem e a uma pequena discrepância nos resultados encontrados na análise química, que HEY (1933) sugeriu que a mesolita da serra de Botucatú fosse reexaminada. Os resultados óticos encontrados pelo autor são pràticamente os mesmos determinados para a mesolita das Ilhas Faeroe.

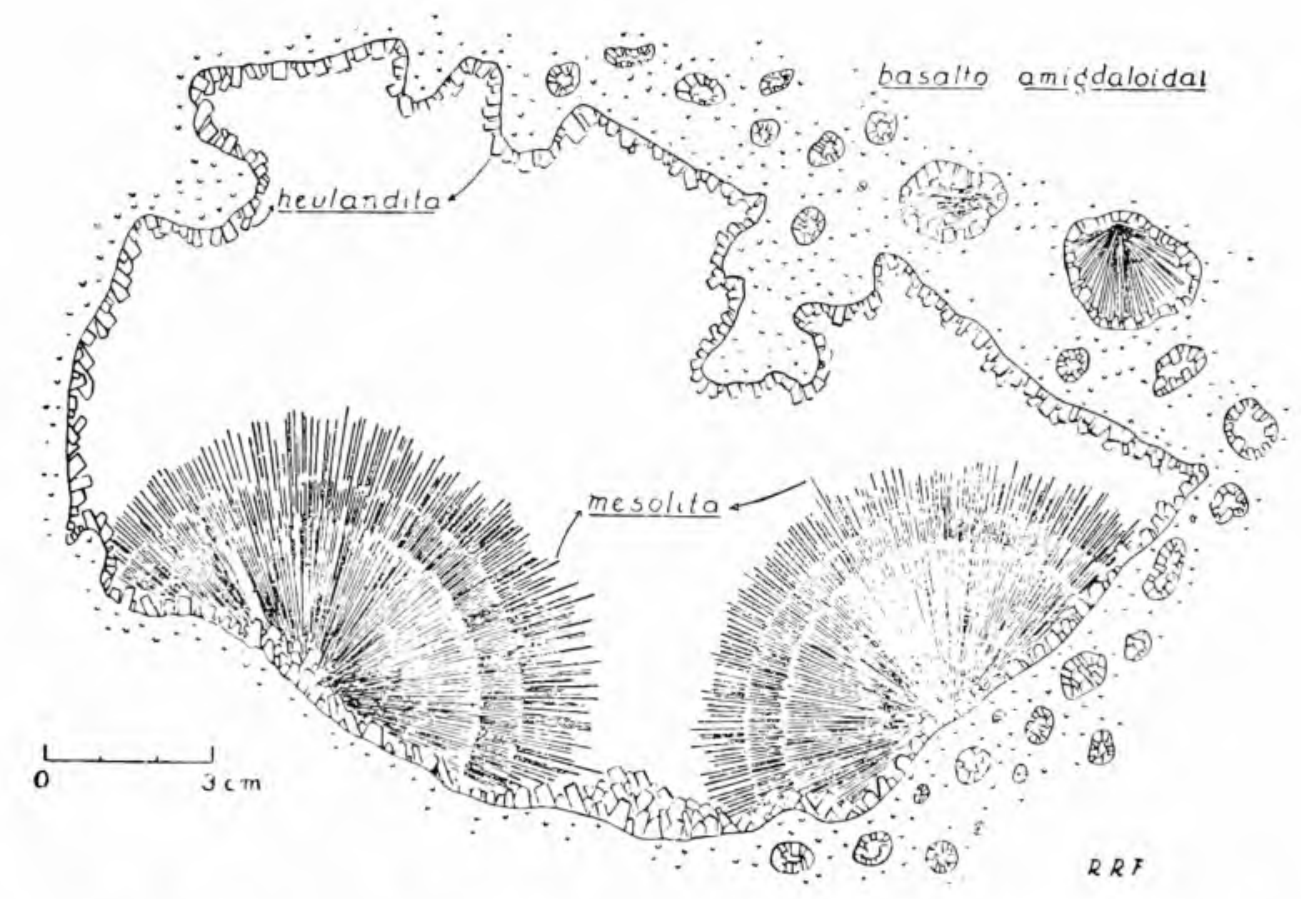

Fig. 2 - Cavidade irregular no basaito amígdaloidal da serra de Botucatu, São Paulo. Notar os cristais de heulandita forrando as paredes internas da cavidade e amígdalas e as massas globóides, fibro-radiadas de mesolita. As partes centrais dessas massas já se encontram inteiramente alteradas em pó branco, muito semelhante a caulim.

As duas análises abaixo foram obtidas de mesolitas da serra de Botucatú e Sertãozinho, São Paulo.

$$
\begin{aligned}
& \mathrm{SiO}_{2} \quad \mathrm{Al}_{2} \mathrm{O}_{3} \quad \mathrm{CaO} \quad \mathrm{Na}_{.2} \mathrm{O} \quad \mathrm{K}_{2} \mathrm{O} \quad \mathrm{H}_{2} \mathrm{O} \\
& \begin{array}{lllll}
\text { Botucatú }-47,61 & 26,80 & 7,08 & 7,80 & 12,11=101,40
\end{array} \\
& \text { ( } \mathrm{n} \beta=1,505) \quad \text { (HussaK) } \\
& \text { Sertãozinho - 45,90 } 27,10 \quad 9,40 \quad 5,20 \quad 0,48 \quad 12,70=100,78 \\
& (\mathrm{n} \beta=1,505) \\
& \text { (I.P.T.) }
\end{aligned}
$$

La a montita - Tem sido encortrada em várias localidades. Cristais relativamente bem formados ( $1 \mathrm{~mm}$ de espessura por $1 \mathrm{~cm}$ de comprimento) são encontrados nas zonas de cizalhamento do diabásio existente defronte da estação da Cia. Mogiana de Estrada de Ferro, 
Mogi-Guaçu, São Paulo e nos km 215-216 do leito da Cia Paulista de Estradas de Ferro (proximidades de Brotas). A forma principal, talvez única, dos cristais é a prismática, desenvolvidos o prisma $\{110\}$ e os pinacóides $\{001\},\{201\}$ e $\{201\}$. Comuns são os geminados de dois indivíduos segundo $\{100\}$, Fig. 5. A grande maioria das amostras examinadas revela a característica eflorescência, na qual a laumontita altera-se em caporcianita, devido à desidratação. Os cristais exibem marcada extinção oblíqua das lâminas de clivagem. Os índices de refração da laumonita de Mogi-Guaçu são: $\mathrm{n} \alpha=1,512, \mathrm{n} \beta=1,519, \mathrm{n} \gamma=1,524$.

Fig. 3 - Entre os cris. tais aciculares de mesolita, havia natrolita, que se alte. rando deixou as agulhas da. quele mineral soltas e destacadas. Secção longitudinal de um agregado globóide, fibro-radiado, constituido de mesolita e natrolita. Mate. rial muito comum em Torri. nha, Sertãozinho e Botucatu, São Paulo.

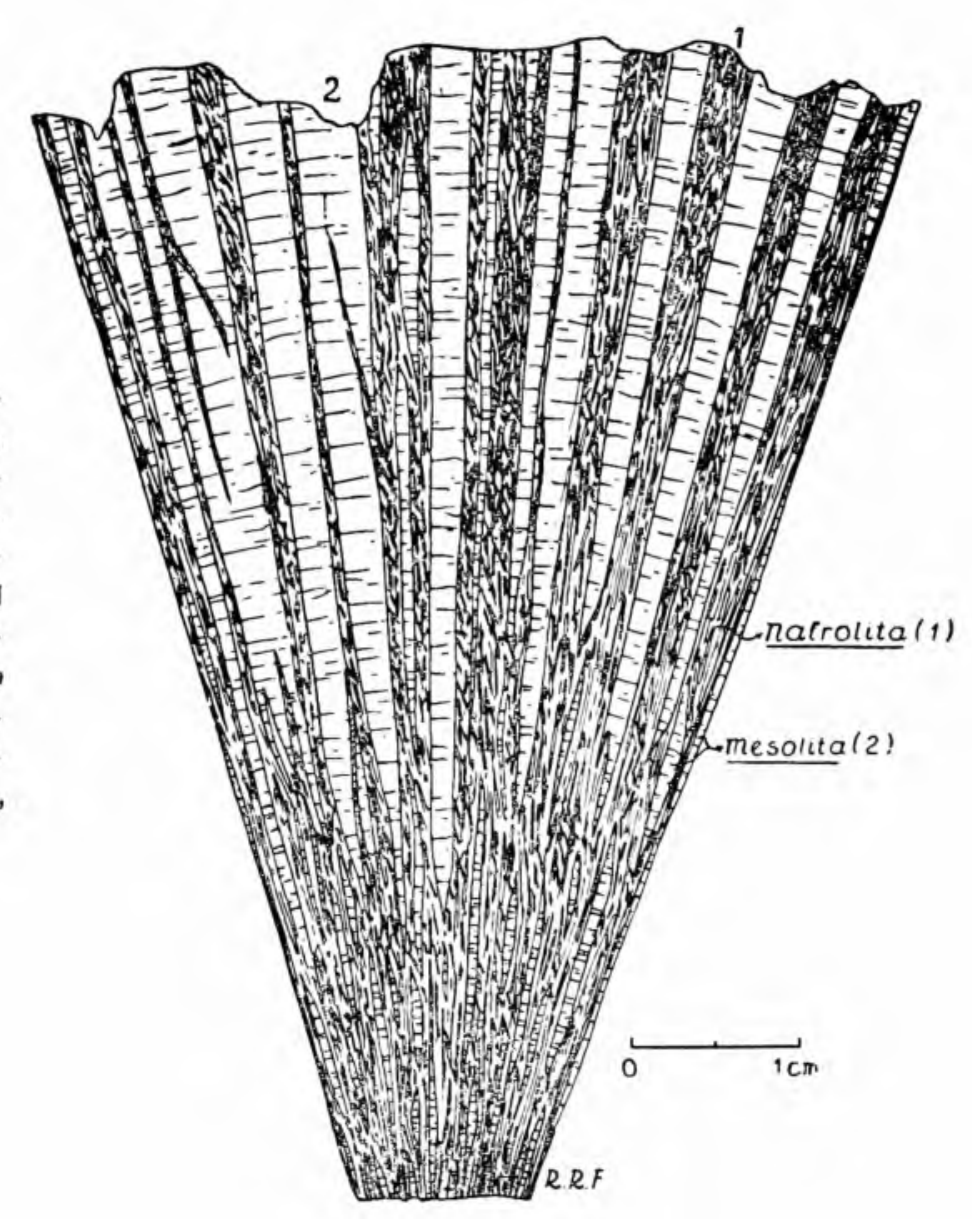

Para a laumontita de Torrinha, São Paulo os índices determinados foram os seguintes $\mathrm{n} x=1,514, \mathrm{n} \beta=1,523, \mathrm{n} \gamma=1,525$. A análise químimica da laumontita de Mogi-Guaçu é a seguinte:

$\begin{array}{lrrrrrr} & \mathrm{SiO}_{2} & \mathrm{Al}_{2} \mathrm{O}_{3} & \mathrm{CaO} & \mathrm{Na}_{2} \mathrm{O} & \mathrm{K}_{2} \mathrm{O} & \mathrm{H}_{-} \mathrm{O} \\ & 51,94 & 20,09 & 11,40 & 0,77 & 0,48 & 16,10=100,78 \\ \text { P. esp. }=2,321 & & & & & \text { (GUILHERME FLORENCE) }\end{array}$

Florence analisou ainda outra zeólita, encontrada na pedreira de diabásio da Cia. Paulista de Estrada de Ferro, estação de Tatú, São 
Paulo, obtendo resultados que sugerem laumontita, conforme pode-se ver na tabela abaixo:

$\begin{array}{rrlllll}\mathrm{SiO}_{2} & \mathrm{Al}_{2} \mathrm{O}_{3} & \mathrm{CaO} & \mathrm{Na}_{2} \mathrm{O} & \mathrm{K}_{2} \mathrm{O} & \mathrm{H}_{2} \mathrm{O} & \text { não det. } \\ 51,94 & 20,58 & 12,75 & & & 13,63 & 2,75=100,00\end{array}$

Essa mesma zeólita foi estudada pelo autor e os índices de refração coincidem perfeitamente com os da laumontita: $\mathrm{n} \alpha=1,513, \mathrm{n} \beta=1,519$, $\mathrm{n} \gamma=1,526$.

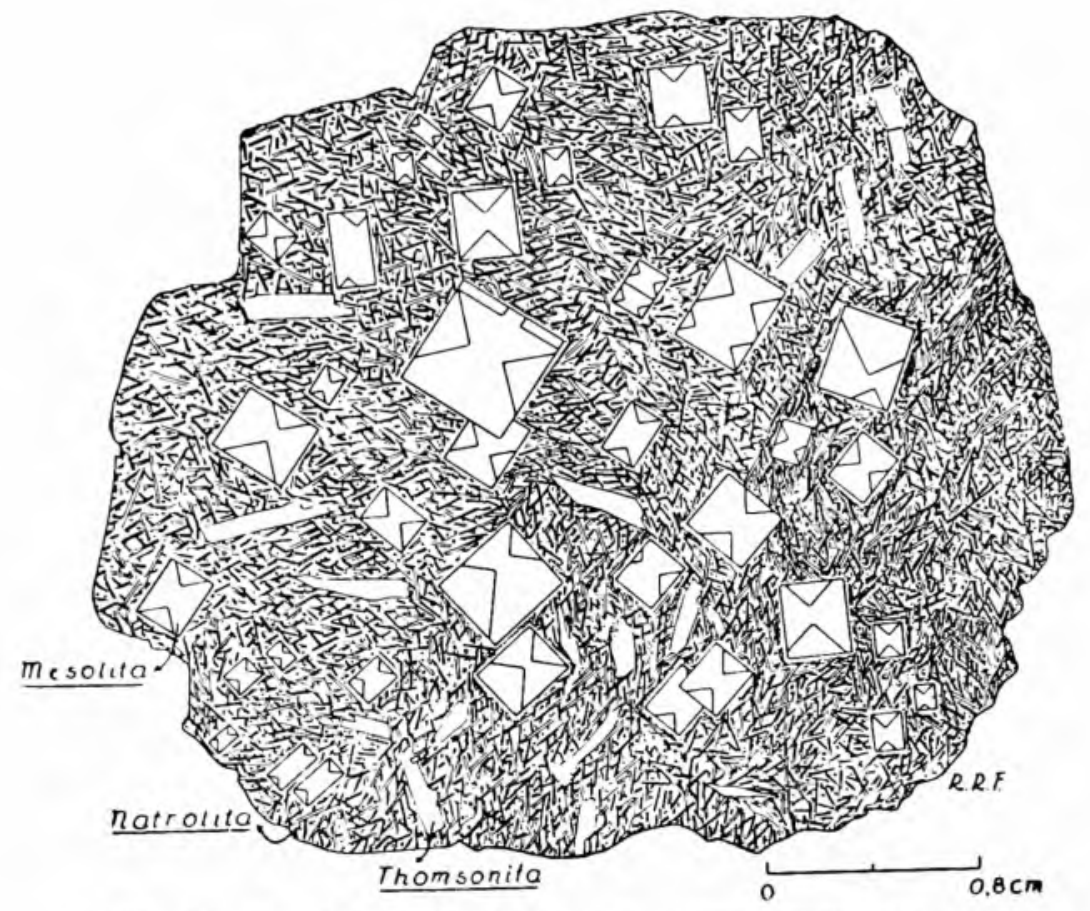

Fig. 4 - Secção transversal ao comprimento dos cristais fibro-radiados de mesolita. Notar entre eles a natrolita e a thomsonita. Como se vê pela ilustração os cristais de mesolita são in. variavelmente geminados. Sertãozinho, São Paulo.

Stil bita - Juntamente com a heulandita, a stilbita parece ser a zeólita mais cornum dos basaltos amigdaloidais do Brasil meridional Apresenta-se, quase sempre, com a forma clássica, isto é, agregados radial-divergentes. Ora se apresenta totalmente incolor, mesmo transparente, ora os cristais estão tintos de vermelho por óxido de ferro. Quase sempre muito bem cristalizada, a stilbita possui, entretanto, hábito muito simples. Desenvolvem-se, de preferência $\{010\},\{110\},\{001\}$, Figs. 6 e 7. As grandes massas de stilbita em agregados sob a forma de leques e feixes da serra de Brotas, São Paulo; dos basaltos amigdaloidais da região de Assis, São Paulo; da foz do rio do Peixe, Paraná; da serra de Botucatú, São Paulo, etc., constituem ótimo material de estudo e amostras de museu, tal a sua beleza. Ao microscópio, principalmente nas seções $\{010\}$, exibem geminação reticulada, muito semelhante à apresentada pela microclina. Stilbitas da serra de Brotas incluem cristais submicroscópicos de quartzo que, a nosso ver, são responsáveis pelo alto teor 
de sílica encontrado na análise química do trabalho de HUSSAK (1890), (Fig. 19).

\begin{tabular}{|c|c|c|c|c|c|c|}
\hline $\begin{array}{l}\text { Brotas, SP } \\
P \text { esp. }=2,24\end{array}$ & $\begin{array}{r}\mathrm{SiO}_{2} \\
-60,82\end{array}$ & $\begin{array}{l}\mathrm{Al}_{2}, \mathrm{O}_{3} \\
16,67\end{array}$ & $\begin{array}{l}\mathrm{CaO} \\
4,25\end{array}$ & $\begin{array}{l}\mathrm{Na}_{2} \mathrm{O} \\
1,73\end{array}$ & $\mathrm{~K}_{2} \mathrm{O}$ & $\begin{array}{l}\mathrm{H}_{2} \mathrm{O} \\
18,12=101,59\end{array}$ \\
\hline do Peixe, Pn & $-55,10$ & 17,10 & 7,80 & 0,74 & 0,70 & $\begin{aligned} 18,80 & =100,24 \\
& \text { (I.P.T.) }\end{aligned}$ \\
\hline & $-54,80$ & 16,80 & 8,60 & 1,10 & 0,12 & $\begin{aligned} 19,30= & 100,52 \\
& \text { (I.P.T.) }\end{aligned}$ \\
\hline
\end{tabular}

Os índices de refração para a stilbita de Brotas, foram os seguintes: $\mathrm{n} \alpha=1,492, \mathrm{n} \beta=1,496, \mathrm{n} \gamma=1,498$. Pura a stilbita de Lins, São Paulo: $\mathrm{n} \alpha=1,494, \mathrm{n} \beta=1,497, \mathrm{n} \gamma=1,500$.

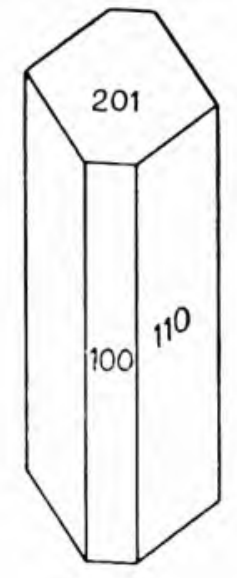

1

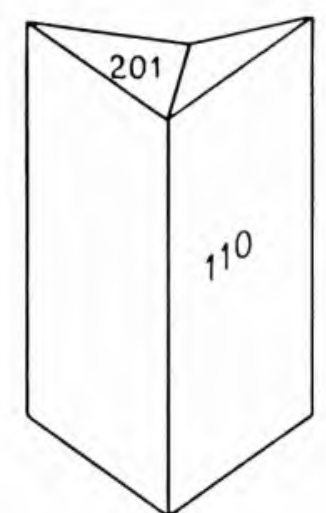

2

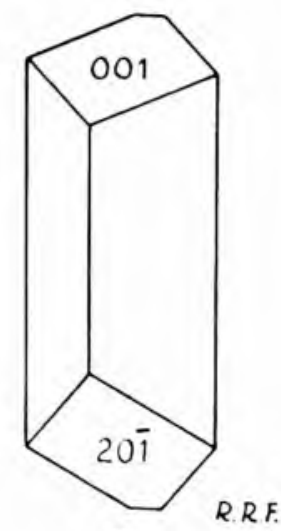

3

F:g. 5 - Principais hábitos e formas dos cristais de laumontita encontrados na pedreira de Mogi-Guaçu, São Paulo.

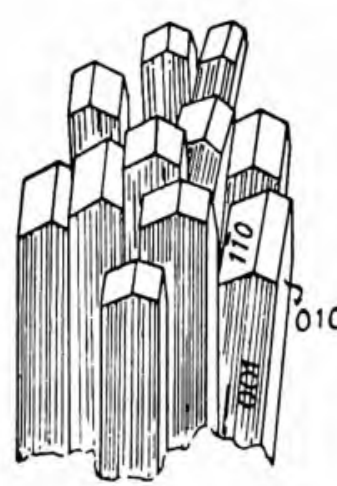

1

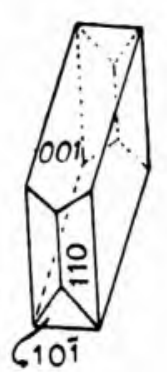

2

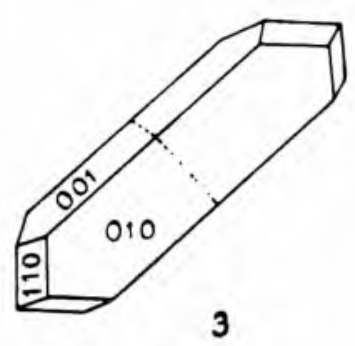

3

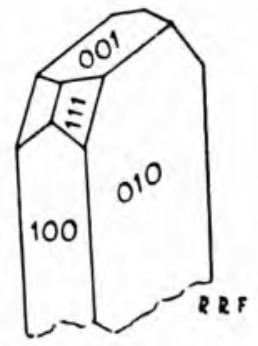

4

Fig. 6 Os numeros 1,2 e 3 representam os principais habitos e formas dos cristais
de stilbita. Numero 4 dá idéia de um cristal de stellerita, discutido no texto.

S t e 11 e r it a - Em uma amígdala do basalto amigdaloidal da pedreira da Prefeitura da cidade de Franca, São Paulo, encontramos uma zeólita, cor de carne, muito semelhante à stilbita que, determinada 
òticamente, mostrou todos os característicos da stellerita. Infelizmente a amostra que possuimos é constituida de poucos e pequenos cristais, não sendo possível proceder-se à análise química. Apresenta-se de hábito diferente, Fig. 6 (n. ${ }^{\circ} 4$ ), e com um número menor de formas do que a primeira stellerita descrita, Morozewicz (1909), procedente das Ilhas Commander, situadas no Mar de Bering.

Enquanto a stellerita das Ilhas Commander apresenta $\{100\},\{010\}$, $\{110\},\{210\},\{111\}$, a de Franca exibe $\{100\},\{010\},\{001\}$ e $\{111\}$.

Os índices de refração da stellerita de Franca são pràticamente os mesmos determinados por MOROzEWICZ:

Ilhas Commander $-\mathrm{n} \alpha=1,484 \mathrm{n} \beta=1,49 \mathrm{n} \gamma=1,495 \gamma-\alpha=0,011$ Franca, SP $-\mathrm{n} \alpha=1,485 \mathrm{n} \beta=1,492 \mathrm{n} \gamma=1,494 \gamma-\alpha=0,009$

$O$ que nos leva a considerar a zeólita de Franca como stellerita, além da grande proximiciade dos índices de refração, são os ângulos entre as faces correspondentes de uma e outra variedade, a falta da geminação da stilbita e a orientação ótica nìtidamente rômbica.

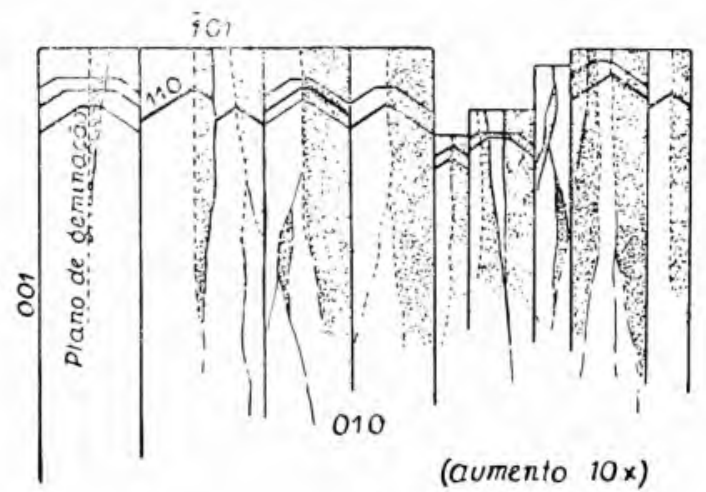

1

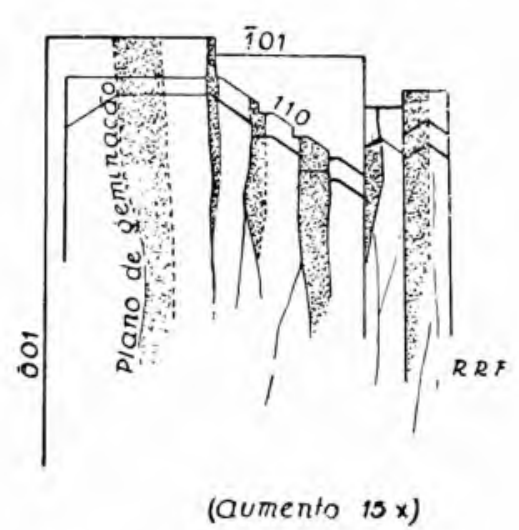

2

Fig. 7 - Secções de cristais de stilbita segundo (010). Notar o plano de geminaç ĩo e as faces de $\{110\},\{001\}$ e $\{\overline{101}\}$. Esta ultima crescendo posteriormente sobre as terminaçoos prismáticas da stilbita modifica-lhe o habito mais comum.

Ilhas Commander

$(110):(1 \overline{10})=89^{\circ}\left( \pm 1^{\circ}\right)$
$(111):(1 \overline{1})=64^{\circ}\left( \pm 1^{\circ}\right)$
Franca, São Paulo não se desenvolvem

$$
\begin{aligned}
& (111):(111)=64^{\circ} \\
& (001):(111)=49^{\circ} 14^{\prime} \\
& (100):(111)=58^{\circ} 34^{\prime}
\end{aligned}
$$

A existência de stellerita tem sido, desde sua primeira descrição por Morozewicz, muito discutida. Assim, PABST (1939), após estudar cuidadosamente as relações entre stilbita, stellerita e epidesmina, conclui que êsses dois últimos minerais são formas idênticas à stilbita e de simetria pseudo-rômbica. PABst, citando ainda WheEler (1927), que obteve para a stellerita de Juneau a mesma relação paramétrica de Morozewicz, diz que aquele Autor não notou a semelhança entre este mineral e a stilbita. 
Embora reconheçamos o valor do trabalho pormenorizado de PABST, que usou também métodos rcentgencgráficcs para mostrar a similaridade existente entre os minerais em discussão, julgamos útil que a zeólita de Franca seja examinada com os mesmos métodos adotados por PABST, pois ela parece possuir muitos dos característicos das stelleritas de Morozewicz e WHEeler.

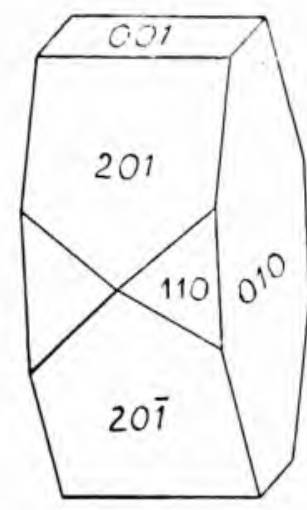

1

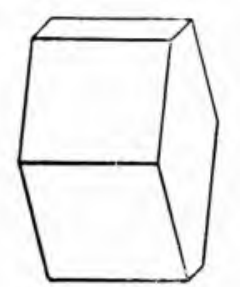

5

Fig. 8 - Principais habitos e formas dos cristais de heulandita.

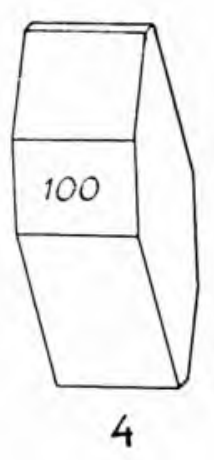

R.RT:

7

He ulandita - Sem dúvida é a mais comum das zeólitas dos basaltos estudados. Apresenta-se de hábitos diversos e em combinações mineralógicas as mais diversas, Fig. 8. Suas dimensões variam dentro de limites amplos e quase sempre se mostram bem cristalizadas.

Abaixo seguem duas análises químicas, a primeira de heulanditas da serra de Botucatú, São Paulo (Analista: Gonzaga de CAmpos) e a segunda de material de Lins, São Paulo, isento de impurezas e alteração (Analista: I.P T., de São Paulo).

\begin{tabular}{lcccccccc}
\multicolumn{1}{c}{} & $\mathrm{SiO}_{2}$ & $\mathrm{~A}_{1,2} \mathrm{O}_{3}$ & $\mathrm{CaO}$ & $\mathrm{K}_{2} \mathrm{O}$ & $\mathrm{Na}_{2} \mathrm{O}$ & $\mathrm{H}_{2} \mathrm{O}$ & & \\
Botucatú & $-58,10$ & 16,67 & 5,90 & 3,26 & 0,61 & 16,16 & $=$ & 100,70 \\
Lins & $-56,50$ & 17,20 & 7,30 & 1,90 & 0,92 & 16,20 & $=$ & 100,02
\end{tabular}

Cristais puros, de Lins, isentos de inclusões e alteração, possuem pêso específico igual a 2,20 . O ângulo $2 \mathrm{~V}$ é sempre positivo, sendo decêrca-de $36^{\circ}$ para as heulanditas de Lins, São Paulo, São Pedro, São Paulo e Foz do Rio do Peixe, Paraná. As amostras estudadas não revelaram a presença de $\mathrm{Ba}$ ou Sr. Amostras puras da região da Foz do Rio do Peixe, forneceram os seguintes indíces de refração $\mathrm{n} x=$ $1,496, \mathrm{n}^{\beta}=1,498, \mathrm{n}^{\prime}=1,501$. 


\section{B - Minerais associados.}

Ao lado das zeólitas encontradas nas cavidades, amígdalas, fendas e zonas de cizalhamento das rochas basálticas e diabásicas, ocorrem numerosos minerais associados que desempenham papel importante na gênese e paragênese daqueles minerais. Se, em muitas amígdalas e cavidades, êsses minerais faltam completamente, em outras são as zeólitas que não se formaram. Em casos particulares, existe entre os minerais associados das zeólitas, completa substituição de uns pelos outros. Assim, em Araraquara, fazenda Miotto, São Paulo, ocorrem belíssimos e grandes cristais de apofilita, totalmente substituidos pela sílica, sem que a forma primitiva dos cristais se tenha modificado.

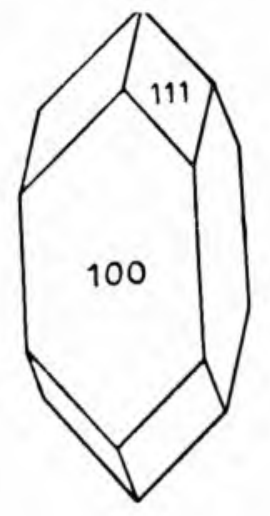

1

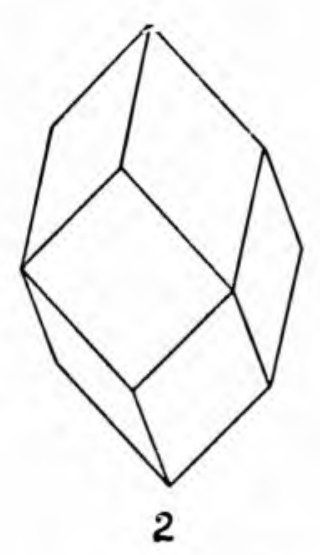

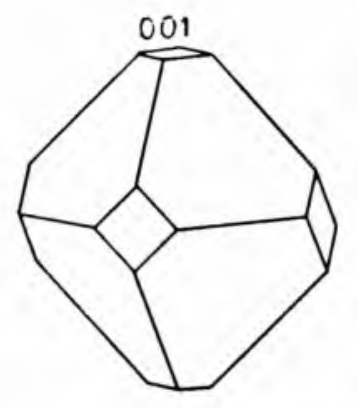

3
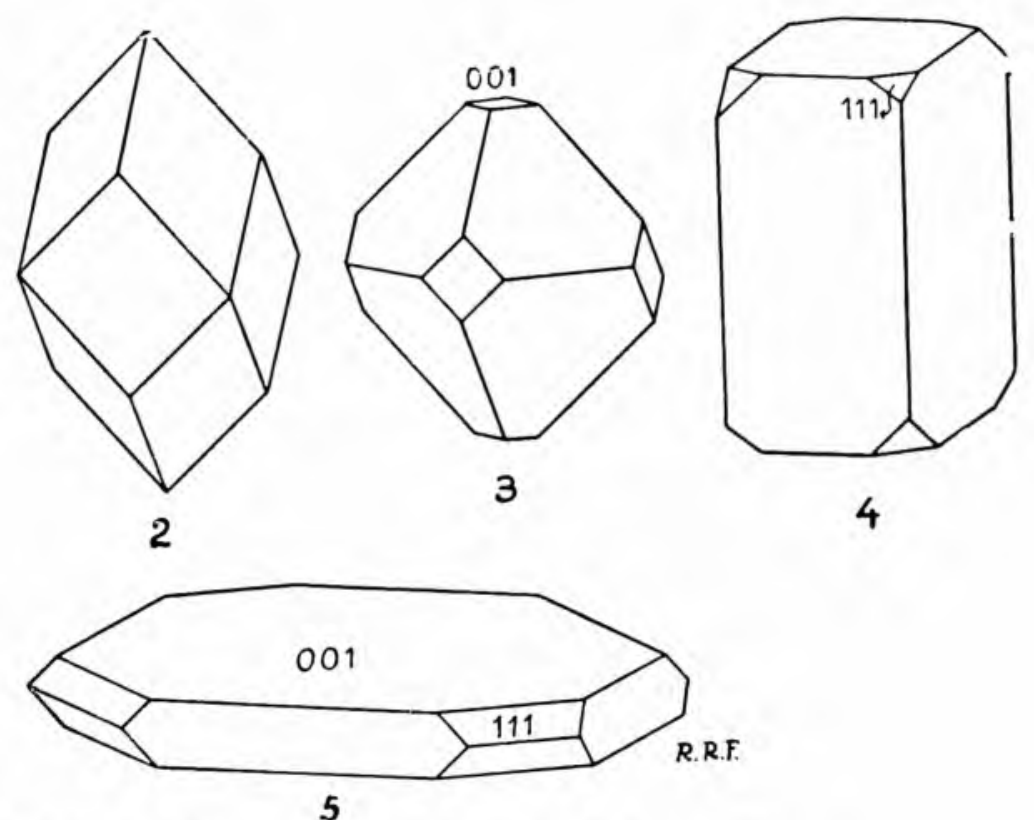

Fig. 9 - Principais hábitos e formas dos cristais de apofilita.

Damos a seguir sucinta descrição dos minerais associados.

D e 1 e s s it a - Ocorre na grande maioria dos basaltos amigdaloidais, emprestando à rocha côr verde característica. Forra geralmente as paredes mais externas das amígdalas.

D a p h n i t a - Nos basaltos da barragem da Emprêsa de Eletricidade Vale Paranapanema S. A., a daphnita ocupa, às vezes, todo o interior de uma amígdala. Outras vezes, ela também serve como material de revestimento de amígdalas, sôbre o qual crescem outros minerais, Fig. 16. Apresenta-se, como se vê na figura citada, em pequenos agregados esféricos ou botrioidais, de estrutura foliáceo-radiada. Sua côr é verde escuro. Sob o ponto de vista ótico é aparentemente uniaxial. Sinal ótico negativo. O índice de refração, nas seções de clivagem (perfeita) basal, é 1,64. Como a daphnita se forma antes da fase de zeolitização é muitas vezes englobada pelas zeólitas, Fig. 16. 
Extraordinária semelhança com a daphnita descrita acima é o material de Salto Grande, Uruguai, que o autor teve a oportunidade de estudar através de amostras obtidas de Jorge Chebataroff.

$\mathrm{C}$ e $\mathrm{l}$ a d o n i t a - Êsse mineral ocorre da mesma maneira que as cloritas, isto é, forrando as paredes das cavidades, amígdalas e fendas. Material celadonítico típico foi analisado por GirotTo, no trabalho de Guimaräes (1933), fornecendo os resultados seguintes:

$$
\begin{array}{lr}
\mathrm{SiO}_{2}- & 53,28 \\
\mathrm{Al}_{2} \mathrm{O}_{3}- & 7,06 \\
\mathrm{Fe}_{2} \mathrm{O}_{3}- & 14,43 \\
\mathrm{FeO}- & 5,95 \\
\mathrm{MnO}- & 0,42 \\
\mathrm{MgO}- & 3,80 \\
\mathrm{CaO}- & 0,71 \\
\mathrm{~K}_{2} \mathrm{O}- & 6,58 \\
\mathrm{Na}_{2} \mathrm{O}- & 1,82 \\
\mathrm{H}_{2} \mathrm{O}- & 6,80 \\
& 100,85
\end{array}
$$

A celadonita de Lins, São Paulo, assemelha-se muito à malaquita e é um produto característico da alteração da rocha matriz. Demonstra-se a origem secundária da celadonita pela pseudomorfose dêsse mineral sobre os piroxênios do basalto. Ao exame microscópico, apresenta-se ordinàriamente de hábito lamelar ou fibroso, este último $\operatorname{com} \alpha=$ amarelo, $\beta=\gamma=$ verde. Embora os índices de refração variem muito, pudemos determinar, pelo método de imersão, os valores seguintes:

$$
\alpha=1,610, \gamma=1,616,(\gamma-\alpha)=0,006
$$

O ângulo dos eixos óticos aparece quase sempre com valor nulo, o sinal ótico negativo. Nossos valores e característicos morfológicos assemelham-se muito aos encontrados por Morgante (1914) e ScheriLLo (1938).

$\mathrm{Quartzo}$ - Mineral comuníssimo nas amígdalas, cavidades e fendas dos basaltos estudados. Apresenta-se de várias côres, o hialino e o ametista sendo predominantes. Curioso hábito de quartzo ocorre em certos basaltos de São Paulo, onde os cristais se apresentam sob a forma de barrilote. Originam-se antes da fase de zeolitização, sendo incluidos principalmente pela heulandita e stilbita, Fig. 19. Os cristais de quartzo ametista, encontrados em geodos e grandes amígdalas em basaltos amigdaloidais do Rio Grande do Sul, atingem às vezes, 20 a 30 $\mathrm{cm}$ de comprimento. São puros e se prestam muito bem para a indústria de lapidação. É fácil verificar, em certos casos, a formação de quartzo de segunda geração, a revestir, sob a forma de cristais microscópicos, os cristais maiores formados anteriormente. Comum é o crescimento alternado de quartzo e calcedônia, no qual a calcedônia se amolda aos cristais de quartzo, originando moldes dêste. 
C a 1 c e d ô n i a e á g a t a - São comuns em nossos basaltos. Exemplares de rara beleza preenchem cavidades e amígdalas dos basaltos da serra da Esperança, Paraná; em Soledade, Rio Grande do Sul; Cornélio Procopio, Paraná. Nas zonas de contato entre as amígdalas e o basalto da barragem da Emprêsa de Eletricidade Vale Paranapanema S. A., ocorrem massas de calcedônia de extrema pureza. Ao microscópio, a calcedônia se apresenta de estrutura fibro-radiada, esferulítica, e sinal ótico negativo.

Todavia, entre êsse material esferulítico, em tudo igual à calcedônia, ocorrem também fibras de sinal ótico positivo, algumas delas com características biaxiais e ângulo dos eixos óticos com valor aproximado de $40^{\circ}$. Há mesmo secções cortadas normalmente a um dos eixos óticos, que facilitaram a estimativa de $2 \mathrm{~V}$ e a identificação do mineral como quartzina. Curioso é notar que as concreções de calcedônia ocupam geralmente as partes mais centrais, enquanto as de quartzina ficam na periferia, fato já observado anteriormente por LEvy e CHALMAS (1892).

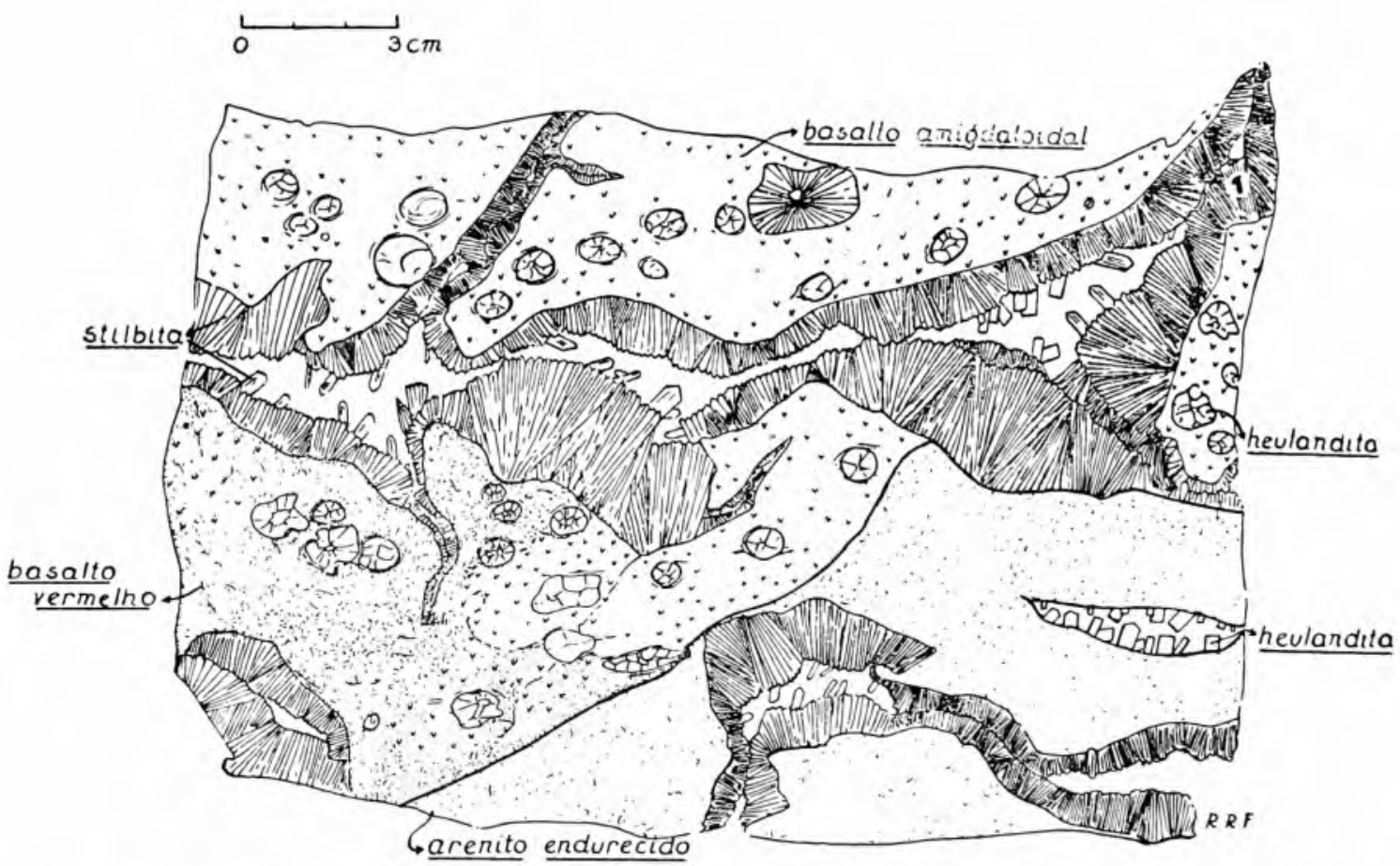

Fig. 10 - Km 215-216 da Cia. Paulista de Estradas de Ferro (proximidades de Brotas, São Paulo). Basalto amigdaloidal sobre arenito. No basaito e arenito formam-se zeólitas, principalmente stilbita. No arenito não ha formação de amígdalas e a deposição do material das soluções se dá em fendas. Notar as duas gerações de zeólitas (stilbita e heulandita de $1 .^{a}$ e $2 .^{a}$ gerações).

$\mathrm{C}$ a $1 \mathrm{c}$ i t a - Mineral muito comum em quase todos os basaltos do Brasil meridional. Nas amígdalas é o último mineral a se formar. É raro não se apresentar muito bem cristalizado, exibindo hábitos diversos. A coloração é também variada. $\mathrm{Na}$ paragênese, parece ocupar papel de pequena importância pelo motivo já acima referido, da época de sua formação. Os cristais de calcita atingem, às vezes, no interior de amígdalas e cavidades dos basaltos, dimensões tão grandes a ponto de fornecerem blocos de clivagem de mais de meio quilogra- 
ma. Se há blocos límpidos, incolores, ocorrem também grandes massas de calcita repletas de inclusões. Comum é o fato dos cristais de calcita apresentarem numerosas figuras de crescimento, figuras de corrosão, sulcos e as mais diversas formas de esqueletos cristalinos. Moldes negativos de calcita com formas de heulandita, apofilita, quartzo, stilbita etc., são frequentes. Interessante, sob o ponto de vista morfclógico é a predominância da forma inversa, $\{02 \overline{2} 1\}$, sobre as demais. Pudemos verificar, pràticamente, quase todos os hábitos e combinações para a espécie: o prismático, o escalenoédrico, o romboédrico, o tabular etc. Nos basaltos de Maracajú, Mato Grosso, a calcita é o mineral mais comum no interior das amígdalas.

Girolita - A única ocorrência de girolita encontrada é a da pedreira de diabásio de Mogi-Guaçu, São Paulo, Fig. 17. Apresenta-se em concreções de estrutura lamelo-radial e de três colorações — branca, amarelada e verde escuro. Macroscòpicamente assemelha-se muito a agregados de talco e clorita. Öticamente, é uniaxial, negativa. O pêso específico, determinado por meio da solução de Thoulet, Hussak (1906) é 2,409. As análises abaixo, executadas por Florence correspondem a dois tipos de girolitas — uma branca (incolor) e outra verde escuro.

Incolor

$$
\begin{aligned}
& \mathrm{SiO}_{2}-52,77 \\
& \mathrm{Al}_{2} \mathrm{O}_{3}-0,73 \\
& \mathrm{Fe}_{2} \mathrm{O}_{3}-\text { traços } \\
& \mathrm{CaO}-33,04 \\
& \mathrm{Na}_{2} \mathrm{O}-0,35 \\
& \mathrm{~K}_{2} \mathrm{O}-0,41 \\
& \mathrm{H}_{2} \mathrm{O}-12,58 \\
& \hline 99,88 \%
\end{aligned}
$$

\section{Verde escuro}

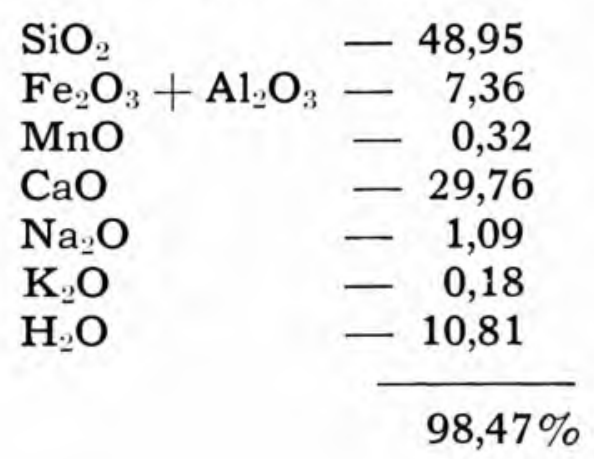

Pela figura referida é fácil verificar que a girolita formou-se antes da apofilita, jamais havendo sido encontrada no interior desta última. Isso vem contrariar a idéia de How, citado por DANA (1920), segundo a qual a girolita se formaria a partir da apofilita. FLEISCHMANN (1910) verificou, também, que a girolita ocorre antes e depois da apofilita, não mostrando qualquer relação com este último mineral e Görgey (1911), cita a sequência girolita apofilita.

A pofilit a - Mineral associado muito frequente em quase todos os basaltos amigdaloidais. Apresenta-se com hábito diverso e coloração variada, incluindo a cor verde, Fig. 9. De todos os minerais associados que ocorrem nas amígdalas e fendas das rochas basálticas e diabásicas é o mais interessante sob o ponto de vista genético e paragenético. Muitas vezes, é o único mineral a se desenvolver. Casos assim são encontrados em Nova Veneza, Santa Catarina, e na pedreira de diabásio da Estação de Tatú, Companhia Paulista de Estradas de Ferro, 
proximidades de Limeira, São Paulo. Os cristais de apofilita alcançam, às vezes, muitos centímetros. Ocupam na paragênese posição mais ou menos fixa, como se verá mais adiante. Os cristais das regióes de Limeira, Mogi-Guaçu e Nova Veneza ora se mostram uniaxiais, ora biaxiais, embora sempre positivos. As anomalias óticas são frequentes. Muitos cristais apresentam-se com côres de interferência anômalas, os aneis da figura de interferência escuros ao invés de coloridos Muito comum é a anomalia mostrada pela apofilita quando em secções paralelas a $\{001\}$. Aparecem, entre nícois cruzados, diversos campos iluminados diferentemente, sendo uns uniaxiais, outros biaxiais. Cristais da pedreira de diabásio da estação de Tatú, São Paulo, isentos de anomalias e inclusões, quando submetidos a pressões laterais tornam-se inteiramente anômalos, com partes uniaxiais e outras biaxiais. Frequente é sua alteração em calcita e caulim. A análise química dú apofilita da pedreira de Tatú forneceu os seguintes resultados.

$\begin{array}{cccccc}\mathrm{SiO}_{2} & \mathrm{Al}_{2} \mathrm{O}_{3} & \mathrm{CaO} & \mathrm{Na}_{2} \mathrm{O} & \mathrm{K}_{2} \mathrm{O} & \mathrm{H}_{2} \mathrm{O} \\ 50,70 & 1,80 & 25,50 & 0,91 & 4,10 & 17,70=100,71\end{array}$

Pirita - Ocorre em Mogi-Guaçu e na pedreira de Tatú, sob a forma de cubos. Nos dois casos, esse mineral se forma sempre após a última fase de deposição dos minerais não metálicos (zeólitas e minerais não metálicos (zeólitas e minerais associados).

\section{V - Basaltos amigdaloidais}

Os derrames basálticos e diabásicos (*) investigados foram sòmente os que continham zonas ou faixas amigdaloidais (ver mapa).

(*) Para evitar qualquer possível confusão no que diz respeito à nomenclatura das rochas basálticas e intrusivas diabásicas, adotada neste trabalho, usaremos termos cujos significados sāo os seguintes:

basalto - equivalente extrusivo (efusivo) de granulação fina, de rochas da família gabro-norito, constituido essencialmente de plagioclásios całco-sódicos (labradorita-bitownita), piroxênios e acessórios, entre os quais a magnetita e magneto-ilmenita são os mais comuns. Quando houver necessidade de maior precisão na definição de determinado tipo usaremos adjetivos apropriados. Assim, teremos: basalto porfírico, basalto ofítico, basalto sub-ofítico, basalto amigdaloidal, basalto vesicular, basalto celular, basalto variolítico etc. Assim, amigdaloidal é o basa:to rico de cavidades de tamanho aproximado de uma amêndoa e cheias de minerais tais como zeoli. tas, ágatas, calcedônea, quartzo, cloritas, apofilita, calcita. Celular o basalto em que as cavidades ocupam mais espaço do que a rocha própriamente dita.

diabásio - rocha de granulação fina a média, ocorrendo em sills e diques e apresentando a composição mineralógica do basalto e textura ofítica. Assim, nessa definição, não consideraremos nem a idade, nem o estado de preservação da rocha.

Para as variedades de basalto e diabásio, em que aparece um ou outro mineral acidental, acrescentaremos o nome do mineral ao nome específico da rocha, ligando-o por meio de hifen, por exemplo, olivina-basalto amigdaloidal, mica-basalto, quartzo-diabásio etc. Almeida (no prelo) e Leinz (1949) adotam a mesma nomenclatura, que é muito semelhante à usada nos Estados Unidos da América.

Pelo exposto, não faremos mençāo aos augito-porfiritos de Hussak (1889, 1906), aos porfiritos e doleritos de WALTHER (1927). Deixaremos de lado a expressão toleito, hoje em de. suso. Basaltito, usado por Guimarães (1933) para os tipos porfíricos, isentos de olivina, nāo será também mencionado. O termo meláfiro, muito usado entre nós para os basaltos amigdaloidais e vesiculares nāo é específico, podendo ser considerado obsoleto. Espilito, outro nome presente em nossa literatura, indicando rochas basálticas cujos feldspatos foram albitizados, deve tam bém ser posto a parte. 


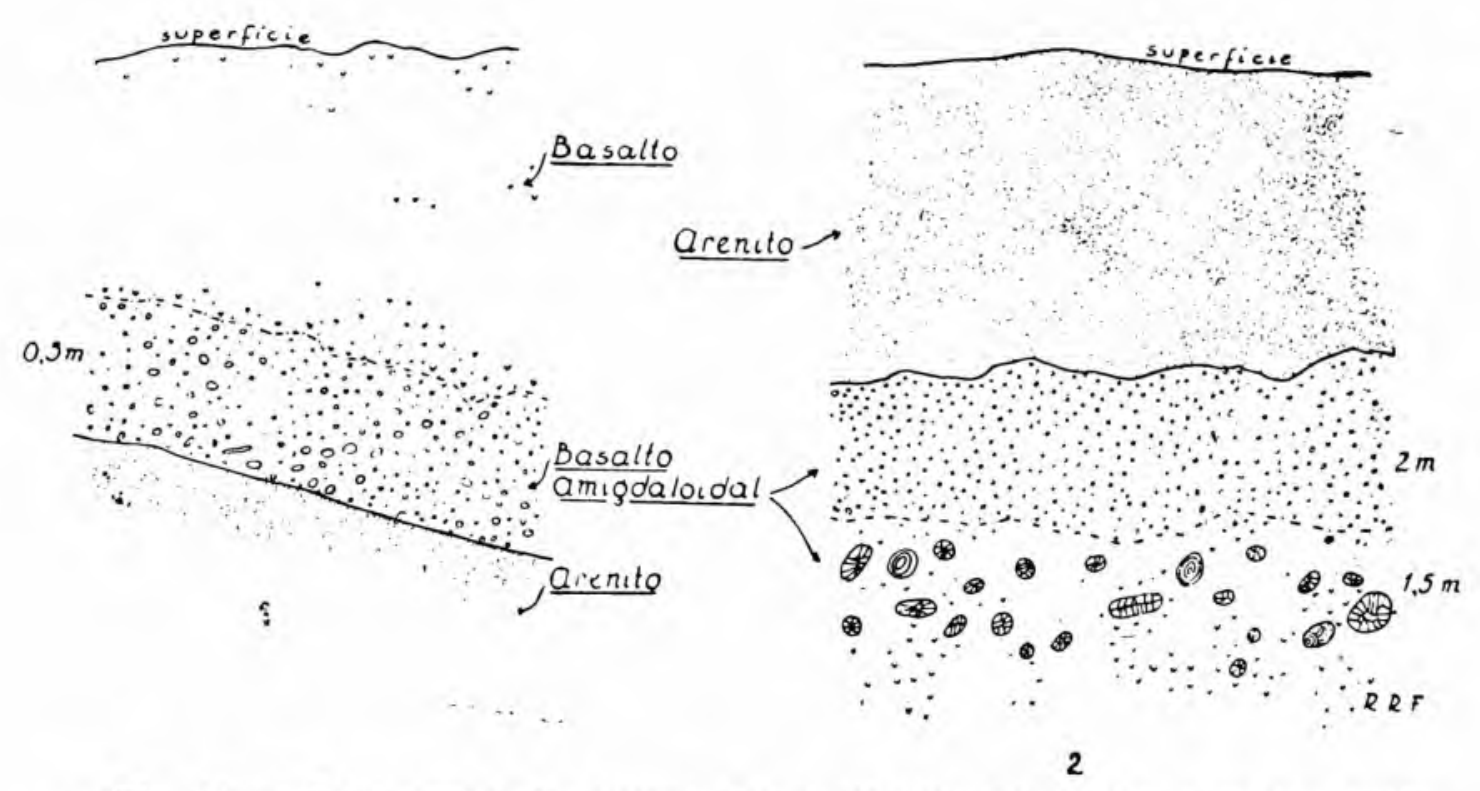

Fig. 11 - Duas secções de derrame. Em 1 (Brotas, São Paulo) a região amigdaloidal do basalto é a inferior, em contacto com o arenito; em 2 (Sacramento, Minas Gerais) é superior. Aqui há uma perfeita diferenciação do basalto, uma zona com grandes amígdalas preenchidas exclusivamente por quartzo hialino $(1,50 \mathrm{~m})$ e outra com amigdalas menores preenchidas por zeólitas (heulandita, stilbita etc.) totalmente alteradas (mais ou menos $2,00 \mathrm{~m}$ ).

Mereceram atenção por igual, os sedimentos arenosos da formação Botucatú, os quais, como poderá ser visto na Fig. 10, foram nìtidamente influenciados pelas mesmas soluções que provocaram a deposição de zeólitas e minerais associados nas amígdalas dos basaltos. Numerosas perfurações feitas em São Paulo mostraram grande quantidade de cristais de heulandita e stilbita, bem desenvolvidos, em arenitos próximos aos derrames. Exemplos assim encontram-se em Sertãozinho, Brotas e Araçatuba, São Paulo. Contudo, nem todos os basaltos formados durante a atividade vulcânica (rética?) e que cobriram extensa área do sul do Brasil e paises fronteiriços possuem no seu topo ou base zonas ou faixas amigdaloidais. Pode-se percorrer, no Estado de São Paulo, dezenas de quilómetros sôbre basaltos, sem que se encontre um único trecho onde ocorram no seu interior vesículas ou amígdalas preenchidas por zeólitas ou minerais associados. Se é certo que muitos basaltos compactos e homogêneos que se encontram atualmente são as partes centrais dos derrames e portanto erodidos em suas possíveis zonas amígdalovesículares superiores, certa é também a existência de basaltos originalmente desprovidos dos minerais acima referidos. A prova disso tivemos na região de Lins, São Paulo, onde o mesmo basalto, no mesmo nível, passa de uma região amigdaloidal, riquíssima de zeólitas, a basalto homogêneo, compacto, afanítico, inalterado, que se extende por grande área. Em muitas outras regiões, tais como São Pedro, Botucatú, Franca e Guará, todas em São Paulo, verifica-se que as faixas amigdaloidais dos basaltos são relativamente restritas e bem localizadas. Tudo indica que houve, durante a solidificação da lava basáltica do derrame, concentração de gases e vapor d'água, responsáveis pela 
formação das amígdalas e minerais de preenchimento. Embora não tenhamos provas suficientes, cremos que essa concentração muitas vezes tenha se verificado nas proximidades dos condutos vulcânicos que puseram em comunicação a parte superior da crosta com a região de onde fluiu a lava basáltica. Somente nessas áreas poderiam ocorrer grandes quantidades de gases e líquidos, porque, à medida que a lava se escoa, às vezes, em derrames não muito espessos (alguns metros ou dezenas de metros) haveria perda gradual dos elementos responsáveis pelo aparecimento das amígdalas e seus constituintes mineralógicos.

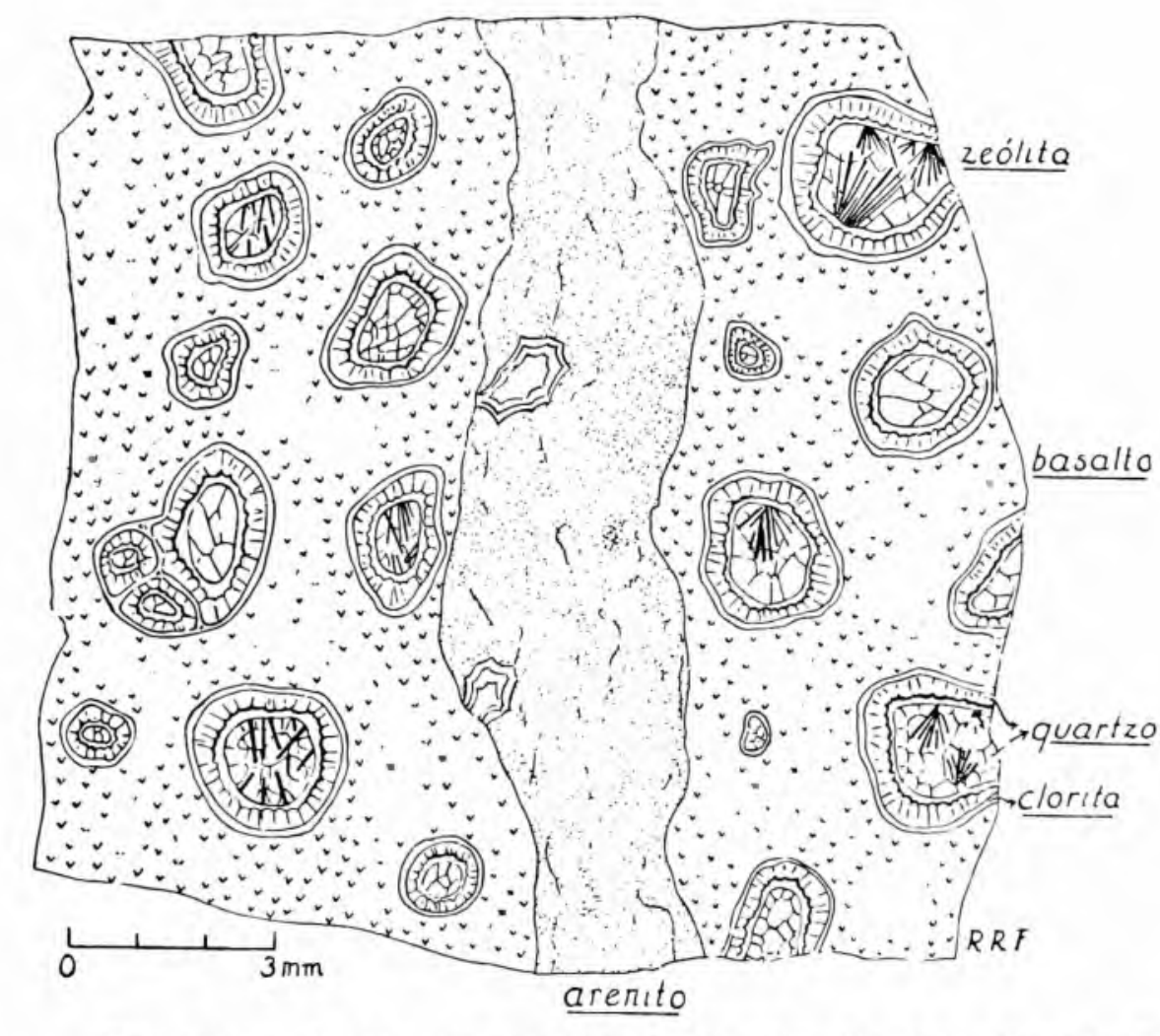

Fig. 12 - Basalto amigdaloidal de Cornélio Prazópio, Paraná. Basalto rico de amígdalas. Elas contém um manto de clorita, quartzo, cal. cedônia e uma zeólita não identificável. Notar um finíssimo dique de arenito cortando a amostra.

A concentração dos gases e líquidos do material efusivo dá-se comumente, em duas zonas - uma na parte superior e outra na parte basal, esta em contacto com o substrato. Aliás, são bem conhecidos os tubos ascendentes descritos em lavas encontradas em muitas regiões do globo. Ocorrem na base da lava e têm a forma de cones estreitos, aproximadamente de $30 \mathrm{~cm}$ de comprimento, por $2 \mathrm{~cm}$ de diâmetro. No seu interior encontram-se os mesmos minerais que ocorrem nas amígdalas normais. Devem sua forma, provàvelmente, à subida de vapores da superfície molhada sôbre a qual corria a lava. Assim, para certos derrames teríamos duas zonas propícias ao desenvolvimento das zeólitas e minerais associados. 
Em 1, Fig. 11, vemos um desses casos, em que a zona amigdaloidal está na base do derrame. Aqui, não verificamos a alternância estrutural dos basaltos descrita por LEINZ (1949) e que seria a seguinte, de baixo para cima: uma zona de basalto vítreo; uma de basalto microcristalino rico em diáclases horizontais; uma de basalto de micro- a macrocristalino com diáclases predominantemente verticais; novamente uma zona com diáclases horizontais e a zona rica em vesículas ou amíg. dalas preenchidas de zeólitas. No caso que estamos considerando, a faixa vítrea não se formou, para dar lugar à camada amigdaloidal in-

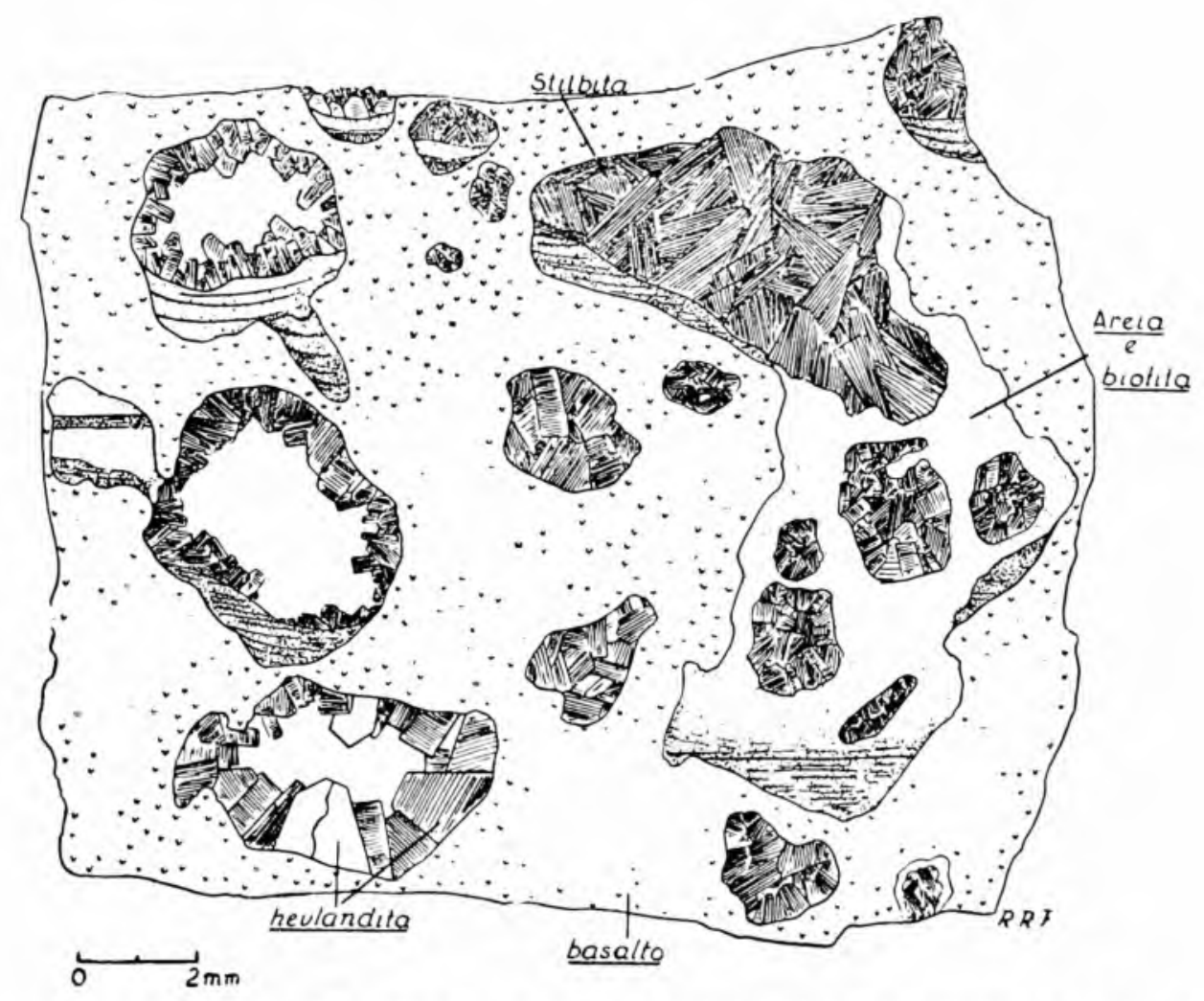

Fig. 13 - Secção delgada do basalto amigdaloidal da pedreira do Cascudo, Mato Grosso. Notar amígdalas de várias formas, umas preenchidas por stilbita, outras por heulandita e terceiras por ambas. No fundo de certas amígdalas e cavidades vêm-se os grãos de areia que se depositaram em camadas após sua inclusāo pela lava.

ferior. Na mesma Fig. 11, em 2, vemos a zona amigdaloidal superior dividida em duas faixas; uma contendo sòmente amígdalas de quartzo e outra rica em zeólitas diversas. Na pedreira da Prefeitura de Franca, São Paulo, ccorre tembém riguíssima zona amigdaloidal no topo do derrame. Nessa mesma zona, encontramos interessante rocha piroclástica, constituida de fragmentos irregulares de basalto compacto e cmigdaloidal. Pudemos notar que o processo de zeolitização continuou ainda após a formação dessa rocha, pois encontramos entre ela e o basalto amigdaloidal zeólitas comuns a ambas. 
Tal rocha é muito semelhante à descrita por LEINz (1949) e encontrada no Estado do Paraná, em Guarapuava.

Derrames pouco espessos não exibem qualquer alternância.

A superfície dos derrames é geralmente plana, não se observando aparelhos vulcânicos (chaminés, crateras) conservados. Isso indica que a lava era muito fluida por ocasião do extravasamento. A presença de analcita, mesmo não existindo ela como mineral pirogenético, nos basaltos amigdaloidais estudados, é outro fato indicativo da fluidez.

Em algumas regiões, entre elas uma pedreira situada a poucos quilómetros da estação de Sussui, São Paulo; a pedreira da Prefeitura de Franca, São Paulo; os cortes da estrada de rodagem situados ao norte da cidade de Ribeirão Preto, São Paulo; as margens do rio das Velhas entre as cidades de Sacramento e Araxá, Minas Gerais; pudemos verificar a existência de basaltos colunares, alguns deles com disjunções também horizontais e às vezes presente a faixa amigdaloidal superior.

Embora tivéssemos estudado numerosas ocorrências de basaltos amigdaloidais, situadas em regiões as mais afastadas, em nenhuma delas verificámos qualquer fenômeno de metamorfismo termal provocado por intrusões de material basáltico de formação posterior. Se tal houvesse ocorrido, as zeólitas situadas na zona de metamorfismo ter-se-iam transformado, em parte, em silicatos calcíferos, tais como, epídoto, actinolita verde, augita, titanita e mesmo grossulária, como acontece, por exemplo, com os andesitos piroxênicos amigdaloidais de Wasdale Head, Westmorland e os basaltos amigdaloidais de Skye e Mull, citado por HARKER (1950).

Numerosos basaltos amigdaloidais, como, por exemplo, os de Cornélio Procópio, Paraná; Fig. 12, Brotas, São Paulo; Serra da Esperança, Paraná; Maracaju, Mato Grosso; encerram em seu interior massas tabulares ou globóides de arenito, endurecidas e sòlidamente cimentadas, distinguindo-se fàcilmente o arenito da rocha que o engloba. Nas zonas de contacto não há qualquer enriquecimento de sílica ou de minerais silicatados, a composição mineralógica do basalto sendo absolutamente a mesma, quer nos pontos de contacto, quer nos afastados. Os minerais silicosos encontrados nas amígdalas (zeólitas, calcedônia, ágata, apofilita, etc.) são os últimos produtos de cristalização das soluções do magma e não o resultado de um enriquecimento a partir de sílica fornecida pelas massas de arenito incluidas pelo material do derrame. A confirmar este ponto de vista temos ainda que muitos basaltos amigdaloidais são ricos em zeólitas, quartzo, ágata, calcedônia, etc., não se verificando a presença de arenito, quer como inclusão, quer nas proximidades.

Outro exemplo a esclarecer o que acima foi dito encontramos em material procedente da Pedreira do Cascudo, Campo Grande, Mato Grosso. Vêm-se nele numerosas cavidades amigdaloidais parcialmente preenchidas por areia incluida pela lava do derrame, Fig. 13. A areia não sendo assimilada se deposita nas partes baixas das amígdalas sen- 
do seguida posteriormente pela cristalização da heulandita, depois de stilbita. No mesmo material, vê-se que em muitas amígdalas não há areia, sendo as amígdalas e cavidades preenchidas exclusivamente por heulanditas e stilbitas ou por uma e outra isoladamente.

Fenômeno muito comum nos basaltos amigdaloidais estudados e que sob certos aspectos se relaciona com a origem das zeólitas e minerais associados é a devitrificação da matéria amorfa do basalto. Por este processo as rochas basálticas modificam-se e se enriquecem de minerais secundários, que se localizam nos lugares onde existia o vidro. Muitas regiões zeolitizadas de nossos basaltos parecem estar ligadas a processos dessa natureza. Isso se evidencia pela forma dos lugares ccupados pela zeólitas, que absolutamente não correspondem a zonas amigdaloidais. Como minerais secundários formados pela devitrificação aparecem plagioclásios alcalinos, quartzo, formações globulares de coloração amarelo ambar, vivo, provàvelmente uma variedade de opala (hullita). Aparecem também elementos pedunculados, fibrosos, microlitos, magnetita pulverulenta, produtos cloríticos, além de um material inalterado, de côr de interferência baixa, sem clivagem, muito semelhante à cristobalita. O vidro é usualmente mais silicoso do que o restante da rocha e representa a parte final, não cristalizada do magma. Raramente encontra-se mesostasis inalterada, com sua côr parda característica. Fragmentos da rocha amigdaloidal de Assis, São Paulo, contendo pedaços microscópicos do vidro inalterado e transparente mostraram ter um índice muito semelhante ao quartzo, isto é, 1.549. Vidro com índice de refraçāo dessa ordem, de acordo com George (1924), pcssui cerca de $55 \%$ de sílica e $10 \%$ de $\mathrm{FeO}+\mathrm{Fe}_{2} \mathrm{O}_{33}$. Ao redor de amígdalas contendo sòmente quartzo, encontradas em basaltos de Franca, São Paulo, aparece muitas vezes uma zona de mesostasis inteiramente descorada, indicando lixiviação do ferro original do vidro. Curiosa é a presença de intercrescimentos de quartzo com os plagioclásios (micropegmatito) nas zonas de devitrificação. A devitrificação da mesostasis se processou, a nosso ver, pela atividade das próprias soluções residuais do magma efusivo, pois minerais fàcilmente alteráveis por intemperismo, como os piroxênios, não mostram sinal algum de alteração.

Dados de interêsse sôbre os resultados de fenômenos de devitrificação em diabásios do Brasil meridional encontramos em Curvello (1946). Êste Autor descreve três tipos de "amígdalas": no primeiro o material de preenchimento é constituido de uma substância vítrea, de côr acinzentada, pontilhada de micrólitos de piroxênio, feldspato e magnetita (fortemente clorcfeitizada), no segundo as "amígdalas" estão cheias de um material de côr parda-escura ou verde-oliva, perfeitamente isótropo e no último, onde as "amígdalas" contém mistura dos dois tipos de material de preenchimento. A alteração da mesostasis primitiva em clozofeita, em consequência da ação deutérica da fase gasosa não prcduziu, equi, qua!quer mineral do grupo das zeólitas ou mesmo minerais asscciados. A inexistência de zeólitas no interior das "amígdalas" do diabásio estudado por Curvello é, possivelmente, explicada pe- 
lo fato da devitrificação ter-se dado acima da temperatura de formação desses minerais. Nos basaltos, onde a queda de temperatura se faz mais ràpidamente, a devitrificação conduz à formação também de zeólitas.

Azambuja (1944), desczeve, na região de Irai, Rio Grande do Sul, interessante vidro vulcânico que, pelas suas características, enquadra-se entre os basálticos. No seu interior encontram-se pequeninos cristais de plagioclásio básico, óxidos de ferro e vacúolos preenchidos por zeólitas.. Se admitirmos com AzAmbuJA, que êsse material vulcânico, (arenito-piroclástico), é o produto de uma sub-divisão esférica e uniforme da lava arremessada pelo vulcão, a zeolitização dos grânulos se deu simplesmente por devitrificação sêca do vidro vulcânico.

A concentração de material silicoso na mesostasis, que se devitrifica por influência das soluções residuais, fornece-nos o material necessário para explicarmos a formação dos numerosos e grandes geodos com quartzo, calcedônia, ágata, tão comuns em nossos basaltos amigdaloidais.
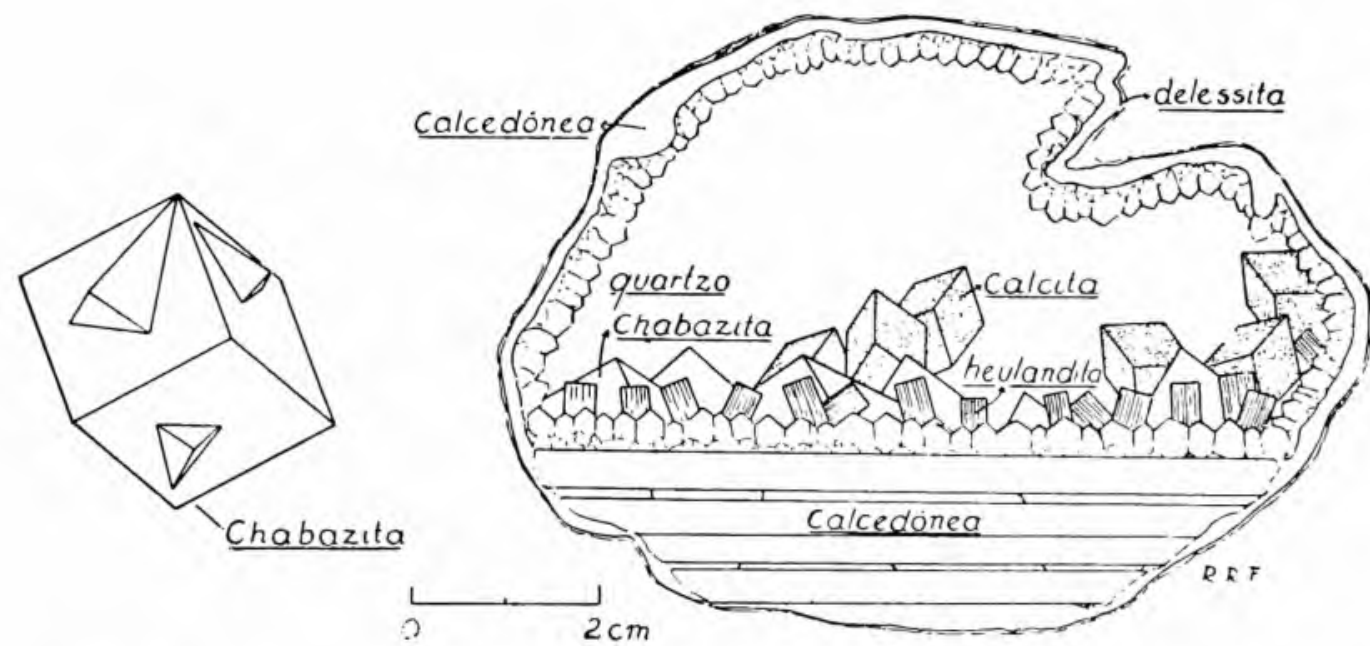

2

Fig. 14 - Cavidade em basalto amigdaloidal da represa da Emprêsa de Eletricidade Vale Paranapanema S. A. Número 1, cristal geminado de chabazita. Em 2 notar: a) calcedônia no fundo da cavidade, em posição horizontal, b) quartzo, bem cristalizado sobre a calcedônia, c) cristais de heulandita sôbre o quartzo, d) cristais de chabazita sòbre a heulandita e quartzo, e) cristais de calcita, última na sequência, crescidos sobre quartzo, heulandita e chabazita.

\section{VI - Diabásios}

As duas ocorrências de zeólitas e minerais associados ligadas a diabásios do Brasil meridional e estudadas detidamente pelo autor foram as de Mogi-Guaçu e Tatú, ambas em São Paulo. Tanto na primeira como na segunda ocorrência, as zeólitas se encontram em regiões de diaclases e zonas de cizalhamento do diabásio, tendo, portanto, gênese e paragênese inteiramente diversas das zeólitas dos basaltos. Enquanto nos basaltos a calcita é indiscutivelmente o último mineral a se formar nas amígdalas e cavidades, Figs. 14, 15, 16, no diabásio, por exemplo o de Mogi-Guaçu, Fig. 17, ela é a primeira a se formar, constituindo parte do substrato para a cristalização da laumontita, girolita, apofilita 

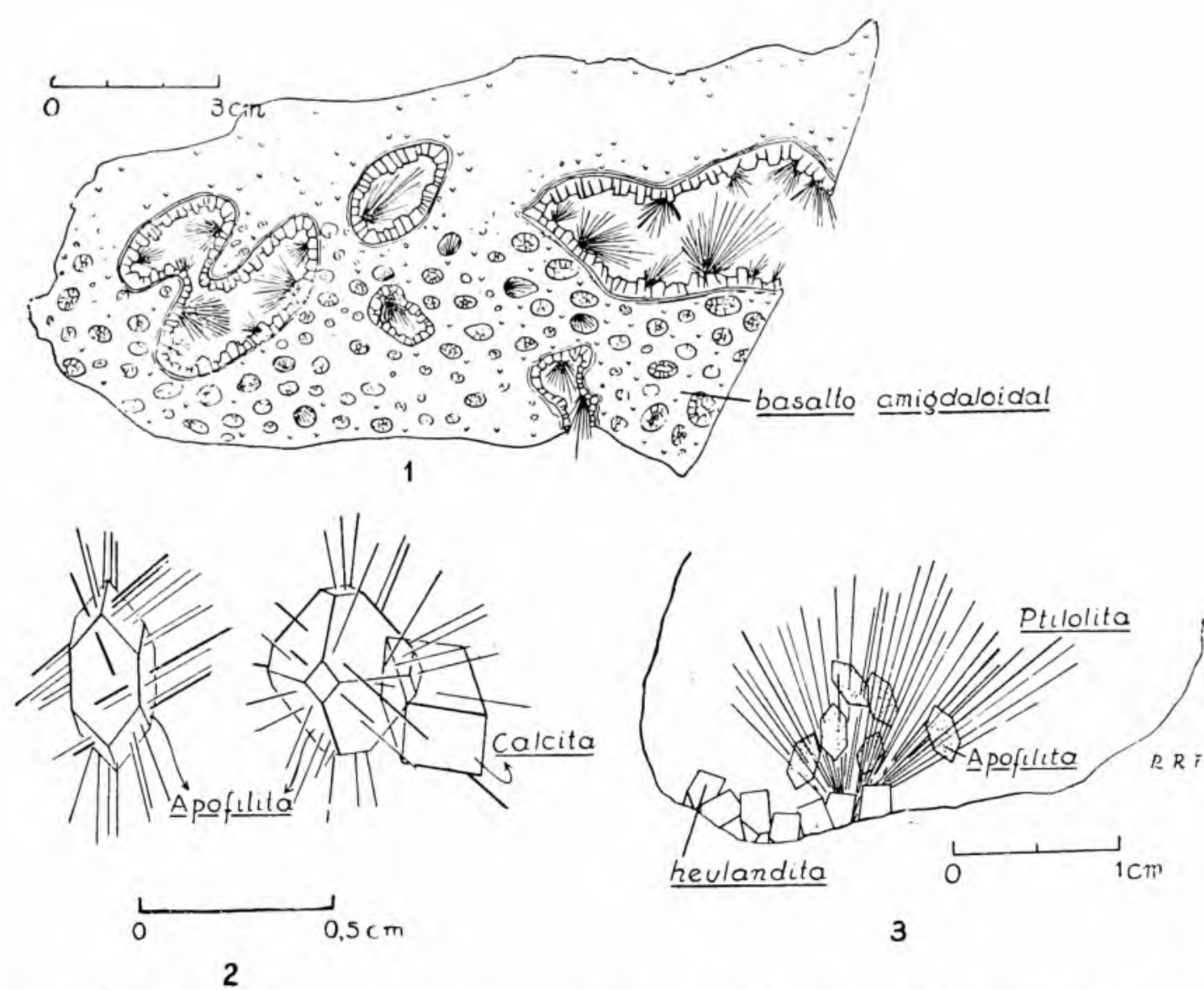

3

Fig. 15 - Basalto amigdaloidal da represa da Emprêsa de Eletricidade Vale Parapanema S. A. Em 1, vê-se o basalto com amigdalas, ora forradas por cristais de heulandita, ora preenchidas por cristais aciculares e finissimos de ptilolita (= mordenita). Ainda, aí, nota-se no basalto a zona onde terminam as amígdalas. Em 2, cristais idionırfos de apofilita sobre ptilolita e calcita crescida sôbre apofilita. Em 3, parte de uma amigdala aumentada. A sequência seria heulandita, ptilolita, apofilita, calcita.

e pirita. Na pedreira de diabásio de Tatú, município de Limeira, verifica-se a mesma coisa, isto é, nas paredes das diáclases forma-se calcita, em certos pontos bem cristalizada, e sôbre ela depositam-se microscópicos mas bem cristalizados indivíduos de stilbita e pirita.

Coutinho (no prelo), analisando os minerais que se formaram nas falhas milonitizadas, posteriores aos movimentos que falharam os blocos do "granito" de São Roque, São Paulo, descreve os mencionados abaixo e na ordem paragenetica seguinte: pirita, calcopirita, galena, fluorita, epídoto, calcita, datolita e apofilita. Aqui, também, vemos que nessas fendas a calcita não é o primeiro mineral a se formar, mas é anterior aos silicatos hidratados (datolita, apofilita), semelhantes às zeólitas e que nos basaltos são anteriores a ela. Como no caso dos basaltos, nenhuma lâmina de diabásio mostrou zeólitas como minerais pirogenéticos.

\section{VII - Análises mineralógica e química dos basaltos e diabásios do Brasil meridional}

O estudo químico e mineralógico dos basaltos e diabásios, principalmente dos primeiros, interessa altamente à compreensão da gênese e 
paragênese das zeólitas e minerais associados, porque é a partir do conteudo químico e mineralógico dessas rochas que se formarão os minerais objeto deste estudo. Segundo a literatura consultada a composição química e mineralógica dos basaltos e diabásios encontrados no Brasil meridional é já bem conhecida e forneceu muitos elementos necessários à análise genética. Foi, ainda, pelos dados consultados e análises mineralógicas procedidas pelo autor, que puderam ser esclarecidos muitos dos problemas apontados atrás, principalmente o da não existência de algumas variedades de zeólitas em nossos basaltos.

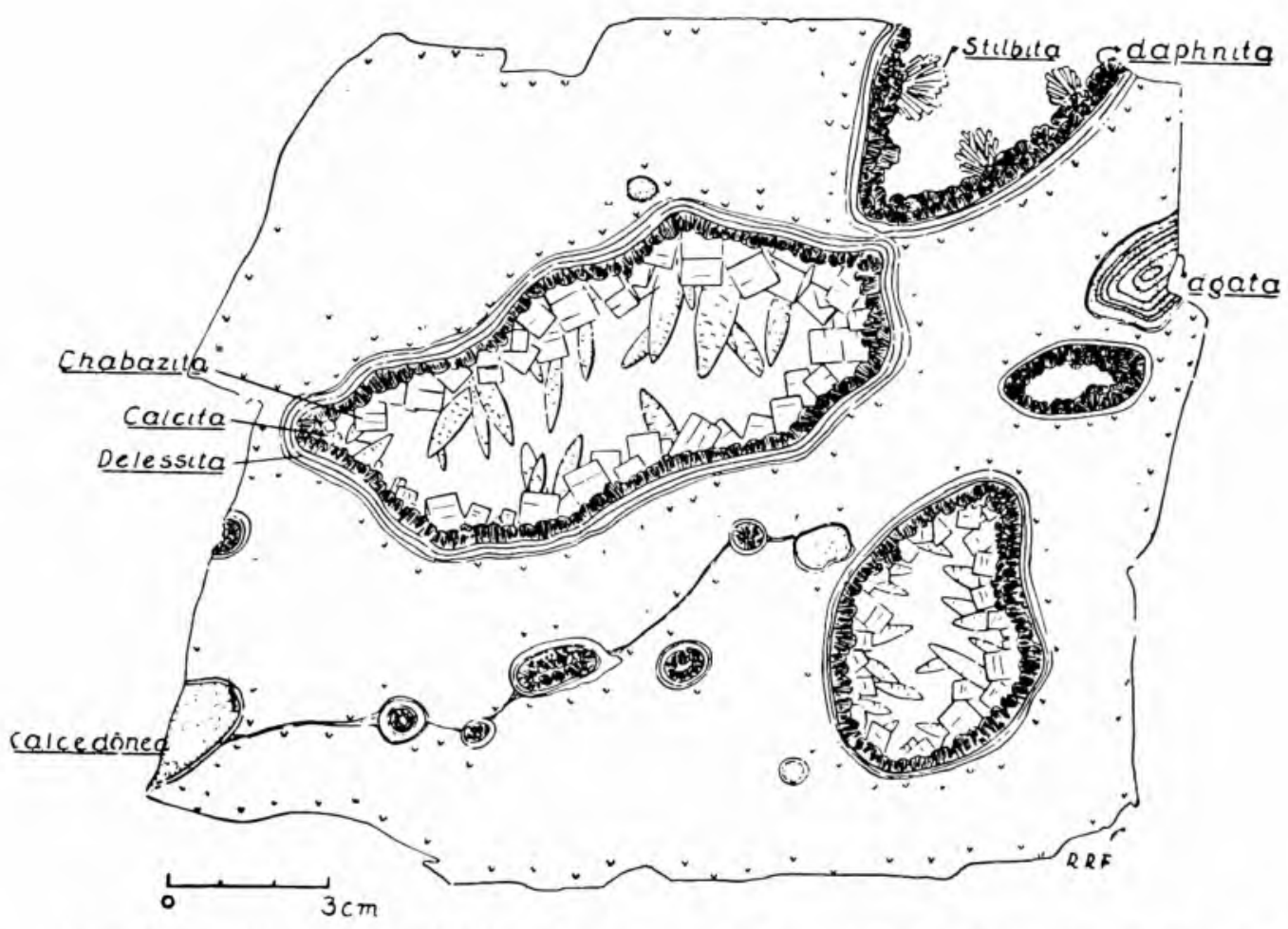

Fig. 16 - Basalto anigdaloidal da represa da Emprêsa de Eletricidade Vale do Paranapanema S. A., São Paulo. Numerosas amígdalas de conteudos mineralógicos diversos. A sequência de formação dos minerais foi a seguinte: a) delessita, b) daphnita, c) heulandita ou stilbita, d) calcita, hábito dente de cão.

Antes de entrarmos no estudo da gênese das zeólitas e minerais associados vejamos algumas análises de basaltos e diabásios do Brasil meridional:

\section{Composição mineralógica}

\begin{tabular}{|c|c|c|c|}
\hline $\begin{array}{l}\text { Leidleito (hialo-dac } \\
\text { (Três Forquilhas e }\end{array}$ & $\begin{array}{l}\text { ito) } \\
\text { Faxir }\end{array}$ & $\begin{array}{l}\text { LEINZ } \\
\text { RS ) }\end{array}$ & $\begin{array}{c}\text { Basalto hialo-ofítico - ALMEIDA } \\
\text { (Fazenda Guanandi, Mt) }\end{array}$ \\
\hline vidro & $64 \%$ & $71 \%$ & vidro $\quad 22,8 \%$ \\
\hline plagioclásio & 26 & 23 & plagioclásio \\
\hline augita & 8 & 5 & piroxênio \\
\hline magnetita e apatita & 2 & 1 & magnetita \\
\hline & $100 \%$ & $100 \%$ & \\
\hline
\end{tabular}




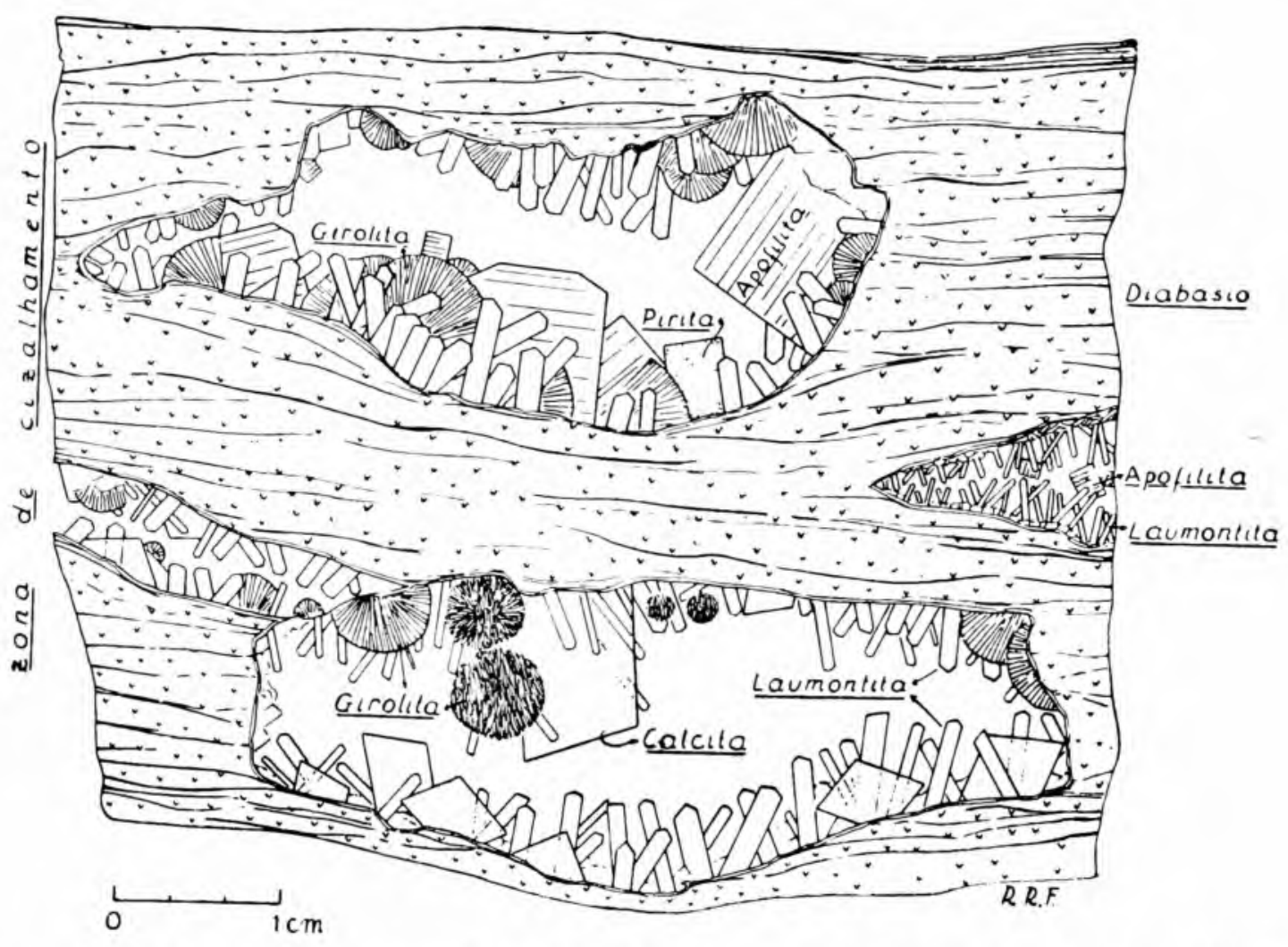

Fig. 17 - Curiosa ocorrência de zeólitas em zonas de cizalhamento do diabásio da pedreira de Mogi-Guaçu, Sào Paulo. Nota-se que a sequência é a seguinte: a) calcita, b) laumontita, c) girolita, d) apofilita, e) pirita. Os cristais de calcita estão localizados nas paredes do diabásio. Sobre êles crescem os cristais de laumontita, que são a seguir envolvidos pela girolita. A apofilita cresce nos espaços deixados pelos minerais mencionados e, às vêzes, sobre êles, como se vê na figura. $O$ cristal de pirita, é de formação posterior, embora não haja muitos indivíduos para comparação.

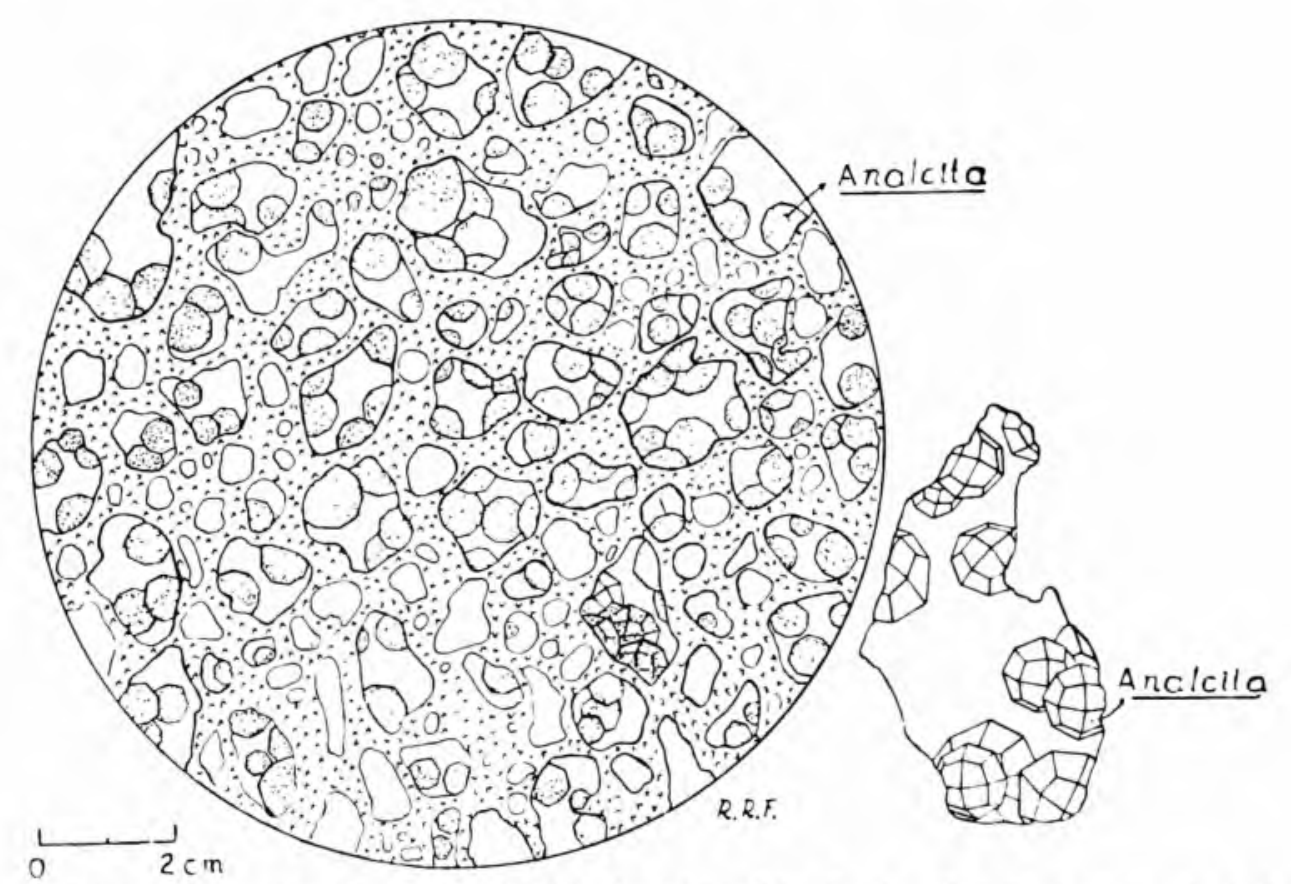

Fig. 18 - Basaito amigdaloidal de Lins, São Paulo. Poroso e com amígdalas preenchidas exclusivamente por cristais idiomorfos de analcita. 
Augito-porfiritos - HUSSAK

(Vale Paranapanema, SP)

vidro

plagioclásio

augita

magnetita

ilmenita

olivina

apatita-rara

hematita secundária

Basaltito - GuimarẽeS

(Rio do Salto, Pn)

mesostásis

andesina-labradorita

diopsídio

magneto-ilmenita

hullita

apatita

\begin{tabular}{c}
$0,1 \%$ \\
31,7 \\
52,8 \\
14,4 \\
0,8 \\
0,1 \\
\hline $99,9 \%$
\end{tabular}

Diabásio - Franco

(Mogi-Guaçu, SP)

plagioclásio (Lab.)

enstatita-augita

magnetita

apatita

produtos de alteração
Basaltos - Almeida

(Planalto Maracaju, Mt)

vidro

plagioclásio

augita e pigeonita

olivina

magneto-ilmenita

apatita

quartzo

hornblenda

biotita

$$
\text { Basaltito - Guimaräes }
$$

(Estrada de Minas e Treviso, SC)

mesostásis

labradorita

$19,3 \%$

diopsídio

17,8

magneto-ilmenita

47,2

hullita

11,6

apatita

3,4

0,4

$99,7 \%$

\section{Diábásio - Curvello}

(Guarei, SP)

plagioclásio $\left(\mathrm{An}_{4 \overline{5}} \mathrm{Ab}_{6 . \overline{5}}\right) \quad 36,6 \%$ augita sub-cálcica $\quad 29,3$

magnetita $\quad 6,1$

mesostase + clorofeita 28,1

\section{Diabásio - Guimarẽes \\ (Ponta Grossa, Pn)}

andesita e labradorita

$33,7 \%$

diopsídio

oligoclásio

albita

quartzo
45,7

0,3

6,7

0,6 magneto-ilmenita

hornblenda

clorita

apatita 
Basalto amigdaloidal - Franco

(Vale do Paranapanema, SP)

vidro

plagioclásio

augita

magnetita

apatita

\author{
Basalto amigdaloidal - FRANCO \\ (Rio Passa Cinco, Mt)
}

vidro

plagioclásio

augita

magnetita

apatita

\section{Composição química}

Sendo nosso objetivo interpretar a gênese das zeólitas e minerais asscciados a partir também dos dados químicos encontrados na literatura damos abaixo, como fizemos com os dados mineralógicos, os resultados médios de quinze análises de basaltos brasileiros, tirados do trabalho de LEINZ (1949).

$\begin{array}{lclc}\mathrm{SiO}_{2} & 49,1 \% & \mathrm{~K}_{2} \mathrm{O} & 1,1 \% \\ \mathrm{Al}_{2} \mathrm{O}_{3} & 13,2 & \mathrm{Na}_{2} \mathrm{O} & 2,0 \\ \mathrm{Fe}_{2} \mathrm{O}_{3} & 6,6 & \mathrm{TiO}_{2} & 2,5 \\ \mathrm{FeO} & 9,2 & \mathrm{P}_{2} \mathrm{O}_{5} & 0,3 \\ \mathrm{MgO} & 6,6 & \mathrm{H}_{2} \mathrm{O}+ & ? \\ \mathrm{CaO} & 8,0 & \mathrm{H}_{2} \mathrm{O}- & 0,7\end{array}$

Infelizmente, nenhuma dessas análises e pràticamente todas as restantes encontradas em nossa literatura fornecem qualquer informação sô-

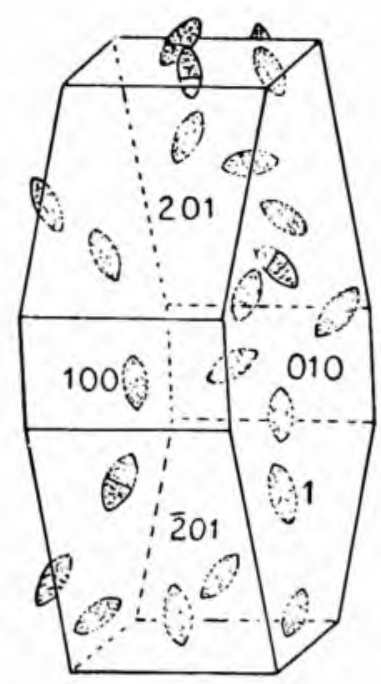

$A$

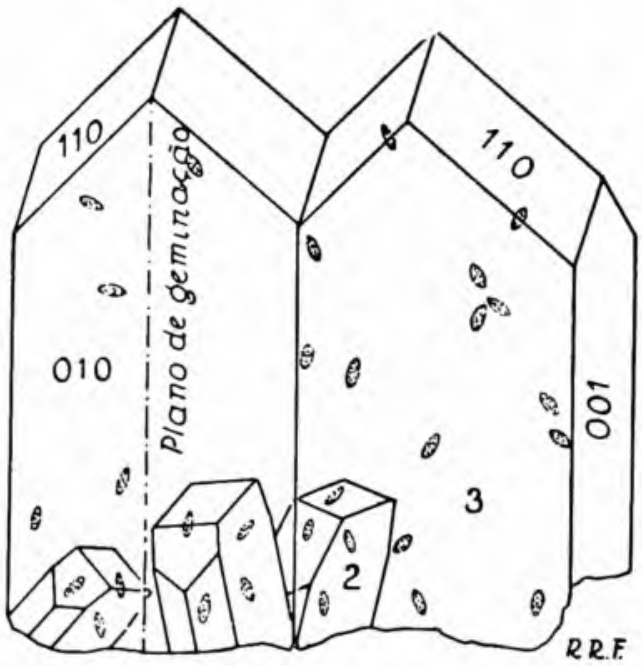

2

Fig. 19 - O número 1 dá idéia das numerosas inclusões de quartzo em fornıa de barrilote (1), microszópicos, no interior de um cristal de heulandita. O número (2) mostra cristais de stilbita de hábito clássico, geminado, incluindo cristais de heulandita e quartzo de forma barrilote. Earragem da Emprêsa de Eletriçidade Vale Paranapanema S. A., proximidades de Assis, São Paulo. 
sôbre a presença ou não, em nossos basaltos, de $\mathrm{BaO}$ e SrO. Esses dois óxidos desempenham papel importante na composição química de determinadas zeólitas, chegando mermo a proporções bem altas. Assim, no harmotomo, o $\mathrm{BaO}$ alcança valores entre 20 e $21 \%$. $\mathrm{Na}$ brewsterita, encontramos cerca de $7 \%$ de $\mathrm{BaO}$ e ao redor de $9,1 \%$ de $\mathrm{SrO}$. Oxido de bário em menor proporção encontra-se também em certas stilbitas e na herschelita.

Pelas análises mineralógicas acima, verifica-se que basaltos e diabásics se constituem de dete-minadas associações mineralógicas, que pràticamente não exibem qualquer variação digna de menção. Há sempre predominância de plagioclásios ricos em anortita, augitas monoclínicas (não enccntramos piroxênios rômbicos ou hiperstenizados) e magnetita. Êsse último mineral pode, em alguns casos, predominar sôbre os feldspatos e piroxênios. Em lâmina alguma, pudemos verificar a presença de olivina no material basáltico estudado, embora diversos Autores Almeida (no prelo), Walther (1927), Guimarães, (1933), HusSAK (1889) e MAACK (1939) a incluam entre os constituintes normais. SCHULzKY, que investigou microscòpicamente algumas amostras de efusivas basálticas coletadas por FREYBERG (1927) diz, também, que em lâmina alguma pôde determinar ccm certeza êsse mineral, razão porque deixou de incỉú-ío na descrição das amostras estudadas.

A inexistência em nossos basaltos de certas variedades de zeólitas seria explicada pela ausência neles dos minerais que, quando alterados, dar-lhes-iam origem. Assim a ausência de epinatrolita nos basaltos do Brasil meridional, seria explicada pela inexistência da sodalita, de que a primeira provadamente deriva.

Da mesma maneira explicamos a ausência de stilbitas com bário, herschelita, wellsita (contém bário e estrôncio) e courzita (contém cerca de $5 \%$ de $\mathrm{BaO}$ e $0,7 \%$ de $\mathrm{SrO}$ ), porque parece nāo haver em nossos basaltos minerais baríferos, como por exemplo, o feldspato potássico com bário. Exemplo de associação harmotomo e feldspatos com bário encontramos no trabalho de Meier (1939), no capítulo em que trata dos pormenores sôbre a sequência paragenética dos minerais dêsse metal. Pela mesma razão, faltam a episcolecita, comptonita, gismondita, por inexistir a sodalita; o harmotomo, epidesmina, phillipsita, brewsterita, erionita por ausência do feldspato potássico, de que parecem derivar.

\section{VIII - Gênese das zeólitas e minerais associados}

Se muitas zeólitas podem originar-se a partir de minerais préformados - epinatrolita de sodalita, natrolita de nefelina, stilbita de sanidino etc., - outros originaram-se, com certeza, diretamente das soluções finais deixadas após a consolidação do magma. Sòmente assim poderíamos explicar a presença de analcita em muitos dos basaltos do Brasil meridional.

Não existindo nesses basaltos a leucita, pelo menos jamais foi encotrada, a analcita não poderia ter-se derivado dela, o que é uma possibi- 
lidade conforme verificação feita por LACRO1X, citado por THugutT (1948), em seu estudo das lavas de Trebisonda. Segundo êsse Autor, a ccnversão da leucita em analcita efetua-se exclusivamente pelas águas de superfície penetradas na lava.

$\mathrm{Na}$ ausência da leucita, a analcita dos basaltos estudados ter-se-ia criginado da combinação dos catiônios, aniônios e água existentes nas soluções finais da consolidação do magma segundo reações que tenderiam, ora para um lad , ora para cutro, conforme a pressão, a temperatura e concentração das soluções:

$$
\underset{\text { albita }}{2 \mathrm{NaAlSi}_{2} \mathrm{O}_{8}}+2 \mathrm{H}_{2} \mathrm{O} \leftrightharpoons \underset{\mathrm{Na}_{2} \mathrm{Al}_{2} \mathrm{Si}_{4} \mathrm{O}_{12 \cdot} \cdot 2 \mathrm{H}_{2} \mathrm{O}}{\text { Analcita }}+2 \mathrm{SiO}_{2} .
$$

A nosso ver foram as soluções restantes da consolidação do magma as principais fontes do processo da zeolitização. Com o aparecimento das vesículas, originadas do despreendimento dcs gases, que durante certo espaço de tempo estiveram sob pressão na lava, as soluções do próprio derrame, carregadas de catiônios e aniônios residuais e localizadas nas cavidades, forneceram os elementos necessários à formação das zeólitas e minerais ass cciados. Não foi necessária e seria mesmo impossivel a destruição dos minerais formadores dos basaltos para a formação daqueles minerais. Os minerais das paredes das amígdalas são na maioria das vezes perfeitamente cristalizados e não dão most:as de qualquer alteração. Aısim, entendemos que cada amígdala deveria ter recebido certa porção dessas soluções, responsáveis pela formação dessa ou daquela zeólita, dessa ou daquela associação mineralógica. Observação idêntica encontramos em Pagliani (1948), que exclui a possibilidade das zeólitas se derivarem da alteraçāo dos feldspatos e recorre a fenômenos hidrotermais, que precederam a fase pneumatolítica, como responsáveis pela formação de zeólitas. Dessa maneira poderíamos explicar a variabilidade de minerais entre amígdalas próximas e vizinhas. Basta uma comparação das figuras desta tese para se verificar o que acima foi dito. Por exemplo, na Fig. 2, encontramos amígdalás preenchidas por heulandita e mesolita, na Fig. 16 por ágata, calcedônia, daphnita, heulandita, stibilita.

A idéia clássica de que as soluções se filtraram na massa porosa da rocha e depositaram aqui e ali seus sais parece não encontrar apoio, pelo menos em nosso caso. Se tal se verificasse seria muito difícil explicar a variabilidade mineralógica entre amígdalas vizinhas.

Por outro lado, se admitíssemos como verdadeira a hipótese das soluções filtrantes, interessando a todas as amígdalas de determinada área amigdaloidal, teríamos com certeza, recorrência ou superposição de zeólitas ou outros minerais associados. Isso não se dá. Cada amígdala apresenta uma ordem paragenética perfeitamente definida, como veremos no próximo capítulo. Isso só é possível se admitirmos sistemas fechados, onde das soluções englobadas se fossem depositando, em determinada ordem, os diversos minerais. 
Admitindo a hipótese de que cada amígdala ou cavidade possui um patrimônio mineral potencial, que pode ser igual ou diferente do de uma amígdala ou cavidade vizinha, a grande maioria das zeólitas pode ser explicada como originada de um processo idêntico ao que vimos acima, para a analcita, isto é, pela combinação dos vários elementos das soluções em condições apropriadas. Assim, para determinadas condições teríamos albita e anortita e para outras natrolita, scolecita e quartzo:

$$
\begin{gathered}
\underset{\text { albita }}{2 \mathrm{NaAlSi}_{3} \mathrm{O}_{8}}+\underset{\text { anortita }}{\mathrm{CaAl}_{2} \mathrm{Si}_{2} \mathrm{O}_{8}}+5 \mathrm{H}_{22} \mathrm{O} \rightleftharpoons \\
\underset{\text { natrolita }}{\rightleftharpoons \mathrm{Na}_{2} \mathrm{Al}_{2 .} \mathrm{Si}_{3} \mathrm{O}_{10} \cdot 2 \mathrm{H}_{2} \mathrm{O}}+\underset{\text { scolecita }}{\mathrm{CaAl}_{2} \mathrm{Si}_{3,} \mathrm{O}_{10} \cdot 3 \mathrm{H}_{2} \mathrm{O}}+2 \mathrm{SiO}_{2}
\end{gathered}
$$

Como essas reações se passam simultâneamente, em ambiente restrito, os cristais de natrolita e scolecita se interpenetram dando massas aciculares radiadas, compostas de uma e outra variedade. Essa é a maneira pela qual êsses dois minerais são comumente encontrados na natureza. Além dessas duas variedades de zeólitas é muito comum entre nós, como se vê pelas ilustrações, a mesolita, que se interpenetra também com as duas primeiras, dado que sua composição química é $\mathrm{mNa}_{2} \mathrm{Al}_{22} \mathrm{Si}_{3} \mathrm{O}_{10} \cdot 2 \mathrm{H}_{2} \mathrm{O}+$ $+\mathrm{nCaAl}_{2} \mathrm{Si}_{3}, \mathrm{O}_{10} .3 \mathrm{H}_{2} \mathrm{O}$. Da mesma maneira poderíamos explicar a formação da chabazita, analcita e heulandita:

$$
\begin{aligned}
& 2 \mathrm{NaAlSi}_{3} \mathrm{O}_{8}+-6 \mathrm{H}_{2} \mathrm{O} \rightleftharpoons \mathrm{Na}_{2} \mathrm{Al}_{2} \mathrm{Si}_{4} \mathrm{O}_{12} \cdot 6 \mathrm{H}_{2} \mathrm{O}+2 \mathrm{SiO}_{2} \\
& \text { albita chabazita } \\
& 4 \mathrm{NaAlSi}_{3} \mathrm{O}_{8}+\mathrm{CaAl}_{2} \mathrm{Si}_{2} \mathrm{O}_{8}+8 \mathrm{H}_{2} \mathrm{O} \rightleftharpoons \\
& \text { albita anortita } \\
& \underset{\text { analcita }}{2 \mathrm{Na}_{2} \mathrm{Al}_{.2} \mathrm{Si}_{4} \mathrm{O}_{12} \cdot 2 \mathrm{H}_{2} \mathrm{O}}+\underset{\text { heulandita }}{\mathrm{CaAl}_{2 .} \mathrm{Si}_{6} \mathrm{O}_{16} \cdot 6 \mathrm{H}_{.2} \mathrm{O}}
\end{aligned}
$$

Se as soluções álcali-cálcicas do resíduo magmático conseguem penetrar no arenito basal sôbre o qual flui muitas vezes a lava, Fig. 10, ai se depositam também zeólitas, idênticas às depositadas nas amígdalas. Este fato permite concluir que, pelo menos nesse caso, as zeólitas se formam a partir de soluções, que já possuem, em estado potencial, o material necessário à formação daqueles minerais.

Pelo exposto conclui-se, também, que cada corrida de lava possuia, em suas partes amigdaloidais, zeólitas que se formaram contemporâneamente à solidificação do magma. Assim, não é necessário que o basalto amigdaloidal (a princípio estaria com amígdalas vazias) fosse recoberto ou por sedimento ou por outra corrida de lava para que as soluções pudessem ser represadas e assim originar as zeólitas e os minerais associados.

Levando-se em consideração as conclusões de LEINZ (1949), de que o magma basáltico atingiu a superfície da litosfera em estado de com- 
pleta fusão, sem cristalização incipiente, o que indicaria sua proveniência do sima ou salsima, podemos concluir que o magma não apresentava qualquer sinal de diferenciação. Se tal fato é verdadeiro e se não houve oportunidade para o aparecimento de fenômenos de diferenciação na lava, nem mesmo de cristalização intratelúrica, todos os elementos raros do basalto devem ter-se disseminado pela massa do derrame, o que impossibilitou a concentraçãc dêsse ou daquele elemento nessa ou naquela zeólita. Se tivéssemcs em nossus basaltos, rochas diferenciadas, não só sob o ponto de vista mineralógico como químico, possiveimente nessas rochas diferenciadas teríamos encontrado as zeólitas que até hoje não foram mencionadas nos basaltos do Brasil meridional.

É fora de dúvida que a origem das zeólitas está também condicionada à temperatura da lava e das soluções formadoras no momento da depcsição. Quanto mais elevada for essa temperatura, tanto mais difícil se torna a formação de zeólitas contendo muita água em sua constituição. Dessa forma poderíamos interpretar o basalto celular de Lins, São Paulo, cujas cavidades estão preenchidas sòmente por cristais de analcita, Fig. 18. Possivelmente a temperatura da rocha que se solidificava era ainda elevada, bem assim a temperatura das soluções, o que possibilitou a formação de analcita (êste mineral possui apenas duas moléculas de água - $\mathrm{Na}_{\ldots} \mathrm{Al}_{2} \mathrm{Si}_{4} \mathrm{O}_{12} .2 \mathrm{H}_{2} \mathrm{O}$ ) e nenhuma outra zeólita. Essa mesma explicação seria válida, também, para os casos semelhantes.

Pelo exposto conclui-se que o processo de zeolitização marca um estágio nítido na história da solidificação da rocha. As zeólitas se formaram de soluções quentes que se resfriaram no intericr das amígdalas e cavidades. Michell (1941) coloca a fase de mineralização das zeólitas no estágio em que soluções quentes passam por um período de resfriamento. Das observações de Michell ressalta que a paragênese das diversas zeólitas encontradas em Striegau é, sob certos aspectos, muito semelhante à encontrada em basaltos por nós estudados, como veremos mais adiante e que pode assim ser esquematizada:

heulandita $\leftrightarrow$ stilbita e epidesmina $m$ laumontita e caporcianita $m$ chabazita.

Eskola (1939) sugere também que o processo de zeolitização é de origem hitdrotermal e que a temperatura fica compreendida entre 100 e $350^{\circ} \mathrm{C}$, raramente mais elevada.

Winchell e Winchell (1951) consideravam as zeólitas como minerais secundários formados quase sempre pela hidratação de silicatos de alumínio, cálcio e sódio etc., derivando-se de feldspatos, nefelina, leucita e sodalita. Pelo que já dissemos antes somos de opinião que tal processo considerado no geral, não está de acôrdo com a realidade. A presença de cristais transparentes, inalterados e idiomorfos de feldspatos, distribuidos por toda rocha amigdaloidal e forrando as amígdalas depõe muito pouco em favor dessa alteração sugerida.

Gordon (1916), discutindo a gênese das zeólitas de New Jersey, U.S.A., abordou a questão da origem da água envolvida no processo de zeolitização e chegou à conclusão de que ela proveiu dos lagos sobre os 
quais a lava passou em sua corrida e parte do próprio magma. Lembra ınesmo, como prova, a existência de depósitos de glauberita e anidrita. que se teriam formado a partir de águas dêsses lagos. O mesmo, talvez, tivesse acontecido no Rio Grande do Sul, onde ocorrem amígdalas preenchidas por gipso e já referidas aqui.

Fenner (1910), que já tinha estudado os mesmos depósitos dis.. cutidos acima por Gordon, diz, por outro lado, que o conteúdo aquoso é ccmpletamente expulso da lava e que portanto a água que provoca a alteração dos minerais deve ser procurada em outra fonte. Para êle, a derivação de fontes meteóricas por um processo de circulação subterrânea parece preencher todos os requesitos necessários à situação, sem oferecer qualquer obstáculo. Acreditamos, pelo menos em nosso caso, que tal processo não deve ter tido lugar. A circulação de águas subterrâneas, carregadas de sais solúveis, teriam zeolitizado não sòmente o basalto amigdaloidal mas também tcdo o sedimento arenoso da formação Botucatú e mesmo rochas de crigem mais recente. Além disso águas de circulação subter rânea teriam provocado a precipitação não só das zeólitas, mas também de outros minerais, além de contribuir para fenômenos de recorrência. a sim, a gênese das nossas zeólitas não parece ter estado ligada a soluções meteóricas circulantes.

GORDON lembra, ainda, a possibilidade das zeólitas se terem derivado da alteração do vidro basáltico pelas águas dos lagos e do próprio magma. Corrobsrando essa idéia, podemos afirmar que em muitos dos basaltos do Brasil meridional é fácil verificar a transformação local do vidro em zeólitas, enquanto regiões não vitrificadas do basalto permanecem inalteradas. Esta origem parece ser muito comum e possivelmente explica, em parte, a diferença de conteudo mineralógico entre amígdalas vizinhas, fato já referido quando tratamos de zeolitização das amígdalas.

\section{IX - Paragênese e discussão}

O estudo metódico e sistemático de numerosos basaltos amigdaloidais encontrados em regiões distintas do Brasil meridional forneceu grande scma de dados, com os quais pudemos traçar o quadrado paragenético das zeólitas e minerais associados. Como veremos a seguir a deposição dos minerais de uma amígdala não se processou de maneira arbitrária e caótica, mas obedeceu a uma ordem perfeitamente definida, que se repetiu sempre, desde que se considerem as associações idênticas. A sequência encontrada é a mesma para basaltos amigdaloidais dos Estados do Rio Grande do Sul, Santa Catarina, Paraná, Sāo Paulo, Minas Gerais e Mato Grosso. Aliás, como já tivemos oportunidade de discuti:, outra não poderia ter sido porque a deposição dos minerais é um fenômeno puramente físico-químico, regido por leis, portanto independente de lugar geográfico e época de formação. 
Considerando os casos mais gerais, nos quais encontramos o maior número de minerais em uma mesma amígdala ou amígdalas próximas, como por exemplo os basaltos amigdaloidais próximos à barragem da Emprêsa de Eletricidade Vale Paranapanema S. A., São Paulo; Cornélio Procópio, Paraná; Torrinha, Franca, São Paulo etc., veremos que há, pelo menos as seguintes fases no processo de preenchimento das amígdalas ou cavidades:

a) fase de deposição das cloritas ou minerais correlatos (geralmente filossilicatos)

b) fase de deposição da sílica (calcedônia, quartzo)

c) fase de deposição das zeólitas

d) fase de deposição da apofilita

e) fase de deposição da calcita

f) fase de deposição dos sulfetos

Muito raramente encontramos toda a sequência descrita. Na maior parte das vezes faltam algumas das fases propostas chegando mesmo a existir uma só, como já foi por nós asinalado. Amígdalas preenchidas exclusivamente por daphnita são comuns em Assis, São Paulo, Fig. 16. Referência também já foi feita ao caso das analcitas de Lins, São Paulo, Fig. 18.

Os resultados a que chegamos do estudo paragenético, levado a efeito nas diversas ocorrências, serão discutidos isoladamente. Do contrário não chegaríamos a estabelecer a ordem normal de deposição. Escolhemos alguns casos típicos, que relacionados entre si representam bem o quadro de paragênese.

\section{1) Barragem da Emprêsa de Eletricidade Vale Paranapanema S. A., São Paulo}

Foi no basalto dessa barragem que conseguimos encontrar os melhores elementos para a definição da sequência. Ai encontra-se grande parte dos minerais descritos anteriormente: A Fig. 14 dá bem idéia da sequência descrita. Primeiramente há deposição da sílica sob a forma de calcedônia. As camadas são absolutamente horizontais e em certos casos há alternância de quartzo sob a forma de cristais límpidos, que revestem toda a parede interior da cavidade, seguindo de perto as irregularidades deixadas pelo manto de calcedônia. A separação entre calcedônia e o manto de cristais de quartzo é, às vezes, tão nítida que é possível a separação um do outro com a lâmina de um canivete. Logo após a deposição do quartzo deve iniciar-se, no seio da solução restante, a formação dos germes de heulandita, que indo ao fundo da amígdala, se desenvolvem sobre os cristais de quartzo. Os cristais de chabazita seguem os de heulandita, depositando-se nestes e nos espaços deixados pelos primeiros mirerais formados. Termina o processo com a formação dos cristais de calcita, que neste caso se apresentam com hábito romboédrico inverso e fortemente colorida em castanho. 
LAZAREVIC (1910) cita a sequência: chabazita $\rightarrow$ apofilita $\rightarrow$ calcita $m$ cobre nativo, muito semelhante a uma analisada por nós, assim constituida: heulandita $m$ chabazita $\cdots$ apofilita $m$ calcita $\cdots$ pirita.

No caso descrito acima bem como em outros, vemos um fato que chama nossa atenção e merece consideração. A calcedônia e o quartzo crescem em toda a extensão da cavidade enquanto os outros minerais se depositam sòmente na fundo dela. Isso significa que no início da deposição as soluções deviam encher totalmente a cavidade, permitindo a deposição de cristais ao redor de toda a cavidade. Com a deposição da sílica, primeiramente sob a forma da calcedônia e depois de quartzo, os germes de heulandita, chabazita e calcita já não se depositam mais nas partes superiores da cavidade, mas caem para a sua parte inferior. $\mathrm{Pa}-$ rece-nos, ainda, que a ordem de deposição dos minerais está ligada a um processo em que vão êles se empobrecendo continuamente em sílica, até o aparecimento de minerais nāo silicatados como sejam a calcita e os sulfetos. Quando a quantidade de sílica não é suficiente para formar calcedônia ou quartzo no interior das amígdalas o primeiro mineral é geralmente uma zeólita.

A Fig. 15 permite analisar mais um tipo de paragênese. Vê-se, em 1 , o contacto de um basalto homogêneo com sua parte amigdaloidal. As amígdalas têm formas e dimensões diversas — umas preenchidas sòmente por heulanditas, outras por ptilolita e terceiras por heulandita $\epsilon$ ptilolita. Analisadas ao microscópio em secções delgadas nota-se a seguinte estrutura; a heulandita forra completamente as paredes das amígdalas, sendo o primeiro mineral a se formar. Logo após, em tufos delicadíssimos aparecem os cristais aciculares de ptilolita, que crescem sôbre a heulandita e os espaços deixados por ela. Em terceiro lugar vem a apofilita, que em cristais perfeitos, piramidais-prismáticos, cresce sôbre as agulhas da ptilolita, sem qualquer orientação. Assim, os cristais de apofilita ficam como que soltos entre os cristais de ptilolita. Finalmente se depositam os cristais de calcita que se amoldam ora sobre os cristais de heulandita diretamente, ora sôbre a apofilita, ora sôbre a ptilolita. Nessa região não vimos amígdalas com quartzo ou cloritas. Esquemàticamente teríamos:

$$
\text { heulandita } \leftrightarrow \text { ptilolita } \gg \text { apofilita } m \text { calcita }
$$

A Fig. 16, ainda no mesmo basalto da barragem é extremamente complexa. Há amígdalas com uma só zeólita e outras com conteudos mineralógicos bem diversos. Assim, existem amígdalas com calcedônia, amígdalas com ágatas, outras com daphnita. As maiores mostram parte da sequência descrita. O primeiro mineral é a delessita, o segundo a daphnita, o terceiro a chabazita e por último a calcita.

No basalto amigdaloidal de Salto Grande, Uruguai, já referido, a sucessão dos minerais de preenchimento é muito semelhante a alguns casos estudados pelo autor. Revestindo as paredes está o quartzo, sob a forma de grânulos microscópicos. Seguem-se-lhes as formações esféricas 
ou botrioidais, de estrutura foliáceo-radiada de daphnita. Sobre esta deposita-se um material fibro-radiado, róseo, muito provàvelmente uma mistura de duas zeólitas (natrolita, thomsonita,). Por último dá-se, em alguma amígdalas, a cristalização de calcita, que então completa inteiramente o espaço da cavidade. Cumpre salientar que o material amigdaloidal de Salto Grande é "sui generis" pelo seu aspecto e constituição, bem merecendo estudo mais pormenorizado. Nele encontramos, também, inc'usões de arenito, à semelhança dos já referidos anteriormente e estudadcs pelo autor.

A calcita da Fig. 16, apresenta-se de hábito escalenoédrico (dente de cão). Em uma das amígdalas, a chabazita está substituida pela stilbita. A fenda que liga algumas amígdalas, na parte inferior da figura, parece ter sido formada posteriormente ao processo de zeolitização.

A Fig. 19 permite analisar o que atraz já foi mencionado. Sobre a calcedônia ou mesmo quartzo crescem pequeninos cristais de quartzo com cerca de meio milímetro ou menores, que ficam inteiramente soltos na amígdala ou cavidade. Iniciada a fase de deposição das zeólitas aparecem os cristais de heulandita, que incluem cristaizinhos de quartzo em número, às vezes, considerável. Posteriormente se depositam cristais de stilbita que incluem, por sua vês, os cristais de heulandita e também cristais soltos de quartzo. Finalmente, sôbre a heulandita, stilbita e quartzo se deposita a calcita. Mais uma vês vemos que entre as próprias zeólitas há também certa ordem definida na deposição: a heulandita precede sempre todas as outras. A stilbita vem sempre depois, enquanto a chabazita se deposita depois. Assim podemos estabelecer as seguintes sequências entre elas:

$$
\begin{aligned}
& \text { heulandita } \# \rightarrow \text { stilbita } \leadsto \text { chabazita } \\
& \text { heulandita } \leftrightarrow \text { ptilolita } \\
& \text { heulandita } \rightsquigarrow \text { stilbita } \ggg \text { laumontita }
\end{aligned}
$$

A primeira sequência é a mesma encontrada por Koritnig (1940).

\section{2) Pedreira de diabásio de Mogi-Guaçu, São Paulo}

A sequência de deposição, neste caso, não corresponde à estabelecida para a deposição em amígdalas e outras cavidades. As soluções atraves:ando as fendas e zonas de cizalhamento depositaram primeiramente calcita, depois laumontita, a seguir giroiita e por último apofilita. Mesmo aqui vemos a repetição de parte da sequência, onde se vêm cristais de apofilita crescidos sôbre ss cristais aciculares prismáticos de laumontita, Fig. 17, parte central à direita.

\section{3) Rio Aguapei, Tupan, São Paulo}

Curiosa sequência encontramos nos basaltos de Tupan, no rio Aguapei. As amígdalas são preenchidas tota!mente por material aparentemente homogêneo e compacto. Em lâminas o material se evidencia em 
dois grupos. No primeiro, vemos nas paredes das amígdalas um manto microscópico de quartzo e calcedônea, que mal se distingue ao microscópio. A seguir, aparecem cristais idiomorfos de analcita que são recobertos por cristais de calcita. Êste último mineral cresce também nas fraturas da analcita, formando como que inclusões. No segundo grupo, o único mineral de preenchimento é a calcita.

\section{4) Serra de Botucatú, São Paulo}

As zeólitas que predominam na serra de Botucatú são principaimente a heulandita, a mesolita e a natrolita. Na Fig. 2, vemos a sequência heulardita $\leftrightarrow$ mesolita. Nas Figs. 3 e 4 , vemos o intercrescimento de mesolita, natrolita e thomsonita, esta sendo a última a se formar. Esquemàticamente, teríamos:

heulandita $\rightarrow$ mesolita $\rightarrow$ natrolita $\rightarrow$ thomsonita

\section{5) Sacramento, Minas Gerais}

O basalto amigdaloidal encontrado nos limites da cidade de Sacramento, Fig. 11(2) apresenta-se com características diferentes das cio:s outros estudados pelo autor. Abaixo do arenito, que recobre a parte superior do derrame, ocorre uma faixa medindo cerca de $2,00 \mathrm{~m}$ de espessura de basalto amigdaloidal, estando as amígdalas preenchidas por zeólitas totalmente alteradas. Abaixo dessa zona ocorre outra, rica de amígdalas e outras cavidades preenchidas exclusivamente de quartzo e ágatas quebradiças. Os cristais quase se desfazem sob a pressão da mão. As ágatas separam-se em zonas. Aliás, todo o basalto está também totalmente alterado. Somos de opinião que as regiões estudadas por FreyberG (1927, 1930), deviam corresponder a zonas como essa segunda agora descrita, onde as amígdalas se acham preenchidas sòmente por minerais do grupo da sílica. É bem possível, que em condições especiais, onde devessem prevalecer a sílica sôbre os outros elementos em solução, fosse possível a formação de zonas espessas de basaltos amigdalcidal, com amígdalas preenchidas por quartzo e ágatas exclusivamente.

A sequência por nós estudada é na grande maioria das vezes muito semelhante às encontradas por outros Autores. Raramente vimos ordens normais de deposição discordantes, a diferença residindo num ou noutro mineral. A comparação entre a sequência aqui determinada e as existentes na literatura dão bem idéia disso.

BrögGer (1890) descreve, por exemplo, uma ordem de deposição que embora nāo seja a mesma estabelecida nesta tese, tem com ela muitos pontos de contacto. Em sua ordem paragenética vemos em primeiro lugar os sulfetos, depois a celadonita, logo a seguir as zeólitas (analcita, natrolita, thomsonita, stilbita), apofilita e por último os carbonatos. Com exceção dos sulfetos, todos os minerais mencionados se formaram na mesma ordem descrita no início dêsse capítulo. 
Michell (1911) localiza também a fase de deposição da apofilita após as zeólitas e a deposição de calcita por último, à maneira de nossa sequência.

GöRGEY (1911), que analisou vários aspectos paragenéticos concluiu também que há certa ordem de deposição dos minerais de preenchimento. Seus resultados mostram claramente que a apofilita se deposita sempre posteriormente a qualquer zeólita e também à girolita, que por sua vez é posterior a qualquer zeólita.

\section{X - Sumário e Conclusões}

Os basaltos e diabásios que cobrem extensa área dos Estados meridionais do Brasil são muitas vezes portadores de diversas espécies de zeólitas (analcita, chabazita, thomsonita, ptilolita, natrolita, scolecita, mesolita, laumontita, stilbita, stellerita e heulandita) e outros tantos minerais associados (delessita, daphnita, celadonita, quartzo, calcedônia, calcita, girolita, apofilita, pirita e cobre nativo). Nos basaltos, os minerais mencionados ocorrem em cavidades de formas diversas, enquanto nos diabásios se localizam nas zonas de cizalhamento. Originaram-se, precìpuamente, de soluções residuais finais do próprio magma basáltico, que ficaram aprisionadas no interior das cavidades, ou nas fraturas dos diabásios. A ordem de deposição dos minerais nas amígdalas e fendas não é tumultuária. Ao contrário, existe nítida sequência, a repetir-se sempre, no material examinado, qualquer que seja a sua procedência. Ós minerais do grupo das cloritas e os do grupo da sílica são sempre os primeiros a se formarem. Seguem-se-lhes as zeólitas, depois a apofilita, a calcita e finalmente os sulfetos. Entre as zeólitas há também certa ordem de deposição. A heulandita precede as demais. $\hat{E}$ seguida pela stilbita, que por sua vês antecede a chabazita. Nas zonas de cizalhamento dos diabásios parece haver uma inversão, a calcita antecedendo a deposição das zeólitas. Há zonas de basaltos amigdaloidais onde as cavidades são preenchidas por uma só espécie de mineral - uma vês sòmente minerais do grupo da sílica, outra sòmente analcitas, mesolitas ou chabazitas. Fenômenos de substituições pseudomórficas entre os minerais de preenchimento das cavidades e fendas dos basaltos e diabásios não são raros. As inclusões de arenitos e mesmo areias da formação Botucatú nas efusivas basálticas não influenciaram, de maneira alguma, a lava que atingiu a superfície. Não há sinais de metamorfismo térmico entre basaltos amigdaloidais mais antigos e lavas ou intrusões diabásicas mais recentes. A ausência de numerosas espécies de zeólitas parece estar ligada à falta de certos elementos na lava e basaltos e também a não existência de tipos petrográficos diferenciados.

Tanto nos basaltos amigdaloidais, como nos homogêneos e nos de outros tipos, bem assim, nos diabásios, não se encontram zeólitas pirogenéticas, tampouco, fenômenos de analcitização. 


\section{XI - Agradecimentos}

O autor deseja registrar aqui seus melhores agradecimentos aos professores Djalma Guimarães, Elysiário Tavora Filho, Heinz Ebert, Reynaldo Ramos de Saldanha da Gama e Viktor Leinz, as críticas construtivas que fizeram à presente tese.

Agradece, ainda, ao professor Fernando F. M. de Almeida as numerosas sugestões apresentadas durante a execução do trabalho, além das viajens que realizou com o autor; à direção do Instituto de Pesquisas Tecnológicas, de São Paulo, a execução de cinco análises de zeólitas; ao dr. William D. Johnston Junior, do U. S. Geological Survey, a remessa de fotccópias de dois trabalhos inexistentes em bibliotecas brasileiras; ao professor Ettore Onorato, da Universidade de Roma, a remessa de extenso resumo bibliográfico; ao dr. Max H. Hey, a coleção de zeólitas enviada e a remessa de todos seus trabalhos sôbre o grupo de minerais estudado pelo autor; ao sr. Deocleciano Soares de Araujo a confecção de numerosíssimas lâminas delgadas e diversas secções polidas; ao sr. Eduardo Ayrosa as fotografias que ilustram esta tese; ao dr. José Giorgi Junior a possibilidade de estudar pormenorizadamente a barragem da Emprêsa de Eletricidade Vale Paranapanema S. A. e as numerosíssimas amostras que forneceu ao autor e aos colegas de trabalho na Faculdade de Filosofia, Ciências e Letras da Universidade de São Paulo, drs. William Gerson Rolim de Camargo e José Moacyr Viana Coutinho e sr. João Ernesto de Souza Campos, as sugestões prestadas durante a preparação do manuscrito.

\section{XII - Bibliografia}

Almeida, F. F. M. (no prelo), Basaltos do planalto de Maracaju, sul de Mato Grosso.

Azambuja, J. R., Jr. (1944), Arenito vulcano-clástico intertrapeano de Irai, Rio Grande do Sul: Min. Met., vol. VII, n. 41, pp. 361-364.

BAKer, C. L. (1923), The lava field of the Parana Basin, South America: Jour. of Geol., XXXI, p. 73.

BrögGer, W. C. (1890), Die Mineralien des Syenitpegmatitgänge der Südnorwegischen Augit — und Nephelinsyenit: Zeitschrift f. Kryst. und Min., vo!. 16, pp. 168-184.

Coutinho, J. M. V. (no prelo), Petrologia da região de São Roque, São Paulo: (Tese de doutoramento em Ciências apresentada à Faculdade de Filosofia, Ciências e Letras da Universidade de São Paulo, pp. 80-82).

Curvello, W. S. (1946), Sobre um diabásio amigdalóide de Guarei, São Paulo: Min. Met, vol. X, n. 60, pp. 263-266. 
DanA, E. S. (1920), System of Mineralogy: 6. ${ }^{a}$ ed., p. 566.

Englert, L. (1925), Bosquejos mineralógicos e geológicos: Egatea, Bol. Esc. Pol. Univ. Porto Alegre, Rio Grande do Sul, vol. X, n. 2, pp. 84-89.

Eskola, P. (1939), Die Entstehung der Gesteine - Die metamorphen Gesteine: Berlin, Julius Springer, p. 382.

Fenner, C. N. (1910), The Watchung basalt and the paragenesis of its zeolites and other secondary minerals: Ann. N. Y. Acad. Sci., 20, p. 93.

Fleischmann, F. N. A. (1910), On the occurrence of gyrolite in County Antrim: Mineral. Mag., vol. XV, n. 71, pp. 288-293.

Franco, R. R. (1939), Breve notícia sôbre a calcita de Botucatú, São Paulo: Bol. Fac. Fil. Ci. Let. XVIII, Mineralogia n. 3, pp. 45-47.

Freyberg, B. von (1947), Observaciones geológicas en la Región de las Agatas de la Serra Geral (Rio Grande do Sul, Brasil): Bol. Acad. Ci. Cordoba, Argentina, Tomo XXX, pp. 129-170.

Freyberg, B. von (1930), Ein Besuch der Achatlagerstätten der Serra Geral in Süd-brasilien: Naturwissenschaftliche Monotsschrift, 43 Jahrg., Heft 9, pp. 257-268.

GEORGE, W. O. (1924), The relation of the physical properties of natural glasses to their chemical composition: Jour. Geol., vol. 32, pp. 353372.

Gordon, S. G. (1916), A review of the genesis of the zeolite deposits of First Watchung Mountain, N. J., U. S. A.: Am. Mineral., vol. I, n. 5 , pp. $73-80$.

GöRGEY, R. (1911), Die Zeolithe des Neubauerberges bei BöhmischLeipa: Mitt. d. Naturwiss. Ver. d. Univ. Wien, 9, p. 17 (tb. citado em Zeitschrift f. Kryst. u. Min., 54, p. 409, 1915).

GuImarẽes, D. (1933), A província magmática do Brasil meridional: Dep. Serv. Geog. Geol. Est. Minas Gerais, Mon. 1, pp. 24-26.

HARKer, A. (1950), Metamarphism: Metheuen \& Co. Ltd., London, pp. 101-14.

Hey, M. H. (1933), Studies on the zeolites. Part $V$ - Mesolite: Mineral. Mag., vol. XXIII, n. 143, pp. 421-447.

Hibsch, J. E. (1921), Compact zeolites: Tscher. Min. Petr. Mitt., 34, pp. $262-265$.

Hussak, E. (1889), Notas petrográficas sobre os augito-porphyritos do Paranapanema: Bol. Com. Geog. Estado S. Paulo, n. 2, p. 33. 
Hussak, E. (1890), Notas sobre zeolitos do augito-porfirito de São Paulo e Santa Catarina: Bol. Com. Geog. Geol. Estado S. Paulo, n. 7, pp. 244-251.

Hussak, E. (1906), Ueber Gyrolith und andere Zeolithe aus dem Diabas von Mogy-Guassu, Staat São Paulo, Brasilien: Centralbla f. Min. Geol. und Pal., pp. 330-332.

KoRItNig, S. (1940), Zeolithe aus dem Moränengeroll des Jamgletschers in der Silvretta: Zentralblatt Min., Abt. A, pp. 177-181 (tb. citado em Mineral. Mag., vol. XXVIII, n. 206, p. 557).

LazAREviC, M. (1910), Ein Beispiel der "Zeolith-Kupfer-Formation" im Andesitmassiv Ost serbiens: Zeitschrift f. prakt. Geologie, 18, pp. 81-82 (tb. citado em Zeitschrift f. Kryst. u. Min., 53, p. 572, 1914).

Leinz, V (1941), Ocorrência de cobre nativo, Santo Angelo, Rio Grande do Sul: Min. Met., vol. VI, n. 31, p. 45.

Leinz, V. (1949), Contribuição à geologia dos derrames basálticos no sul do Brasil: Bol. Fac. Fil. Ci. Let. CIII, Geologia n. 5, pp. 1-61.

Leme, A. B. P. (1914), Les zéolites du rio do Peixe (Brési1): Comptes Rendus de L'Académie des Sciences, t. 158, pp. 416-418.

LÉvy, M. e Chalmas, M. (1892), Mémoire sur diverses formes affectées par le réseau élémentaire du quartz: Bul. Soc. Franç. Mineral., t. 15, pp. 160-190.

Lyons, J. B. (1944), Igneous rocks of the northern Big Belt range, Montana: Bull. Geol. Soc. Amer., vol. 55, pp. 445-472.

MAACK, R. (1939), Exploração geográfica e geológica em Santa Catarina (Brasil): Dep. Nac., Prod. Min. - Trad. do original: Geographische und Geologische Forschungen in Santa Catarina (Brasilien ) por G. F. Alvim, pp. 40-50.

Meier, A. E. (1939), Association of harmotome and barium feldspar at Glen Riddle, Pennsylvania: Am. Mineral., vol. 24, n. 9, pp. 540-560.

Michell, H. (1911) Ein neues Zeolithvorkommen im böhmischen Mittelgebirge: Tscher. Min. Petr. Mitt., 30, pp. 482-492.

Michell, W. D. (1941), Paragenesis of the pegmatite minerals of Striegau, Silesia: Am. Mineral., vol. 26, n. 4, pp. 262-275.

Millosevich, F. (1908), Appunti di Mineralogia sarda. Il giacimento di zeoliti presso Montresta: Atti della reale Acad. dei Lincei, Anno CCCV, vol. XVII, pp. 266-271.

Morgante, S. (1944), Zeoliti della zona di Dessié e Diredaua in A. O.: Atti Real Ist. Ven. Sci. Let. Art., t. CIV, pp. 406-425. 
Morozewicz, J. (1909), Ueber Stellerit, ein neues Zeolithmineral: Bull. Acad. Sc. Cracovie, parte 2, pp. 344-359.

Oliveira, F. de P. (1889), Reconhecimento geologico do vale do rio Paranapanema: Bol. Com. Geog. Geol. Estado S. Paulo, n. 2, pp. 3-31.

PABst, A. (1939), The relation of stellerite and epidesmine to stilbite: Mineral. Mag., vol. XXV. n. 164, pp. 271-276.

Pagliani, G. (1948), Le zeoliti del granito di Baveno: Per Min. Ano XVII, n. 1-3, pp. 175-188.

Pelikan, A. (1906), Ueber zwei Gesteine mit primärem Analcim nebst Bemerkungen ueber die Entstehung der Zeolithe: Tscher. Min. Petr. Mitt., 25, pp. 113-126.

Scherillo, A. (1938), La celadonite delle rocce erutive dell'altipiano eritreo: Per. Min., vol. IX, n. 2, pp. 253-264.

STEWART, F H. (1941), On sulphatic cancrinite and analcime (eudnophite) from Loch Borolan, Assynt.: Mineral. Mag., XXVI, pp. 1-8.

Thugutt, S. J. (1948), Zeolites: Chemical properties and origin, An. Soc. Geol. Pologne, vol. XVIII, pp. 5-35.

Walther, K. (1927), Contribución al conocimiento de las rocas "basálticas' de la formación de Gondwana en la América del Sud. Inst. Geol. Perf. Uruguay, Bol. n. 9, pp. 9-12.

Walther, K. (1938), Eruptivos afro-brasileño-argentinos de edad permotriasico-eojurásica. La supuesta uniformidad del maǵma "melafídico" y sus relaciones con la parentela alcalinítica: Inst. Geol. Perf. Uruguay, Bol. n. 24, pp. 117-167.

Wheller, E. P. (1927), Stellerite from near Juneau, Alaska: Am. Mineral., vol. 12 , n. 9, pp. 360-364.

Winchell, A. N. e Winchell, H. (1951), Elements of Optical Mineralogy: John Wiley \& Sons, Inc., New York, pp. 330-348. 


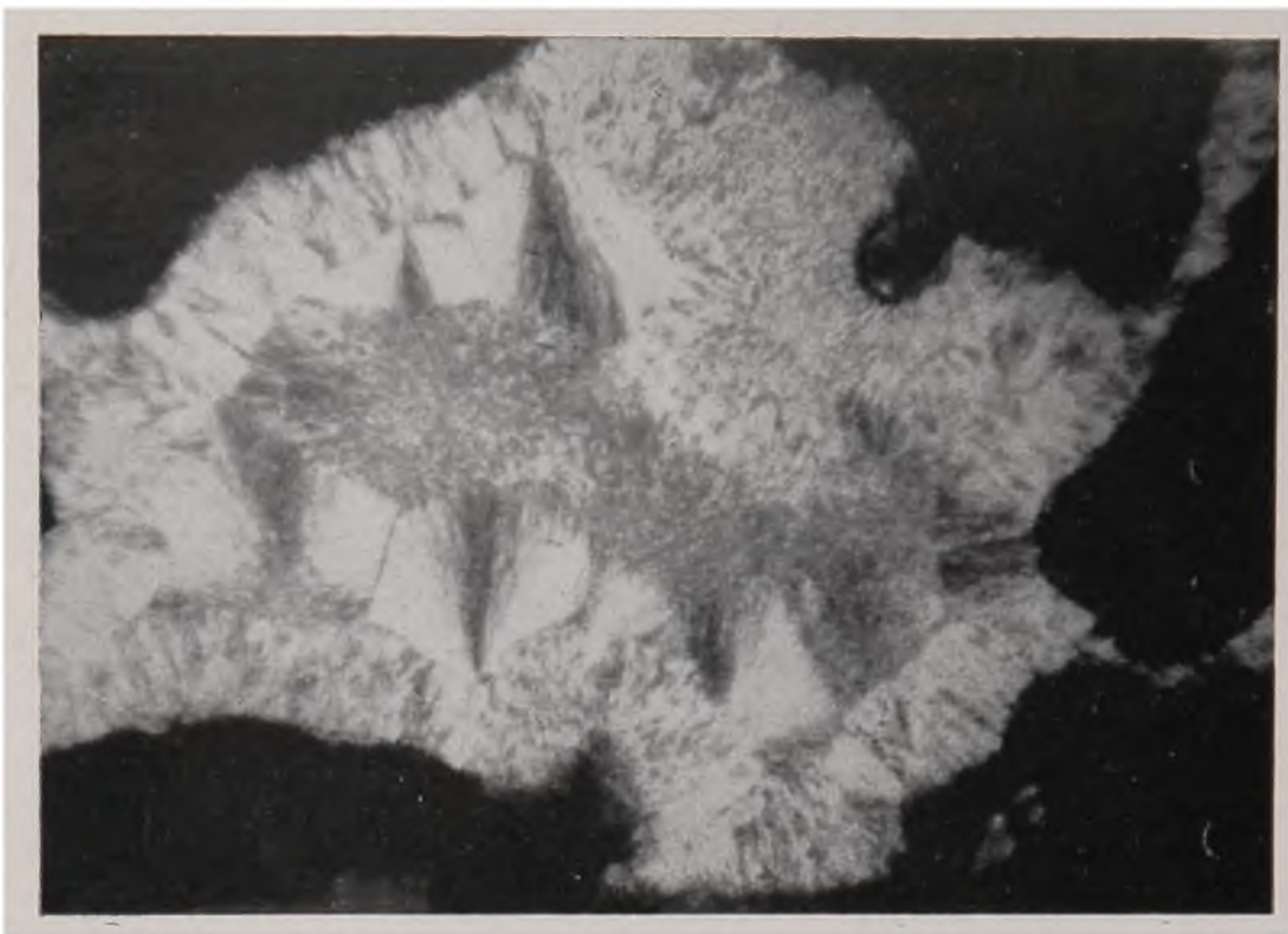

FOTOMICROGRAFIA 1 - Basalto da barragem da Empresa de Eletricidade Vale do Paranapanema S. A., proximidades de Assis, São Paulo. Calcedônia e quartzina fibro-radiadas entre material misrogranular, isótropo (opala?). $30 \mathrm{x}-$ Nícois cruzados.

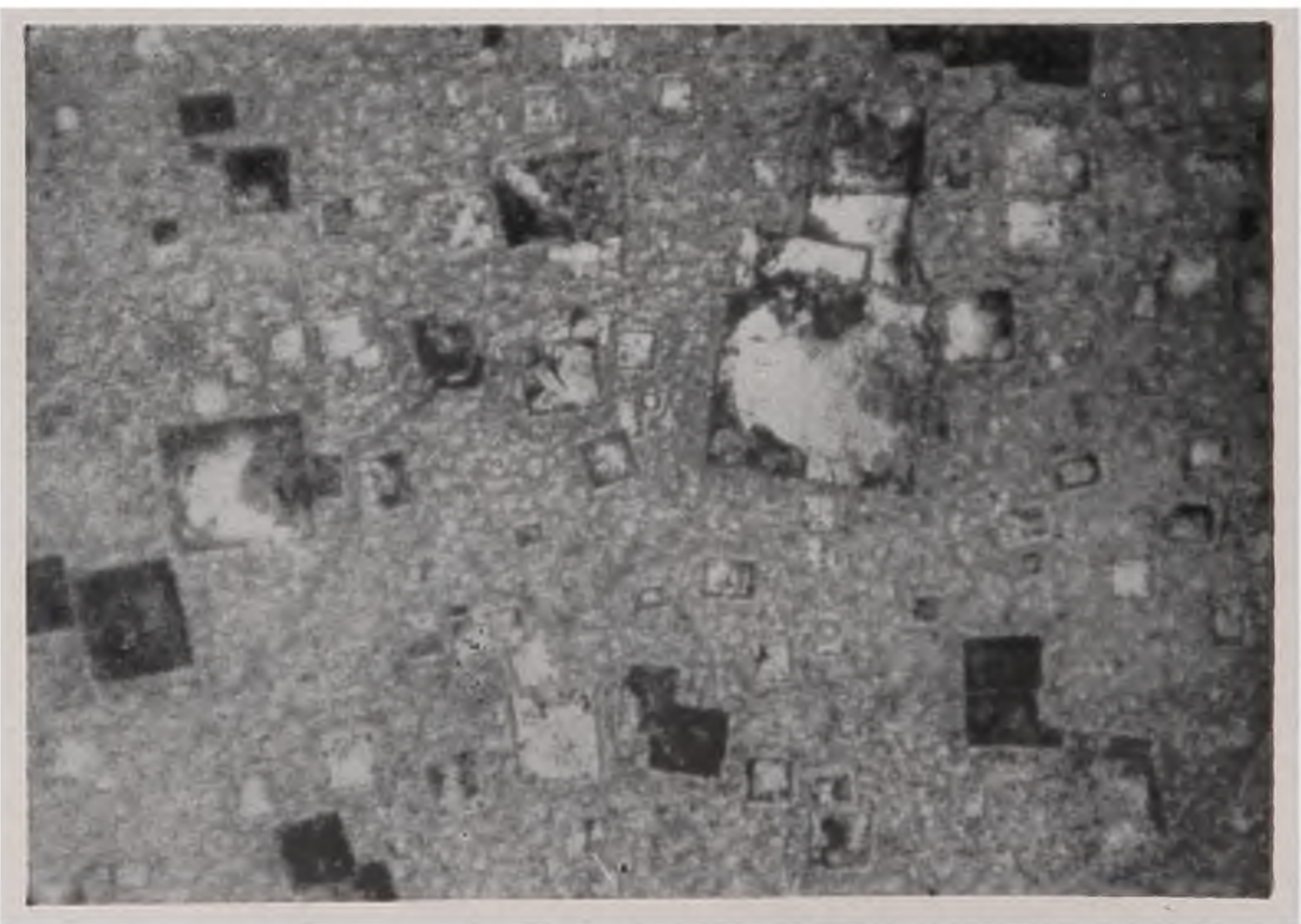

FOTOMICROGRAFIA 2 - Sertãozinho, São Paulo, Mesolitas cortadas normalmente ao seu comprimento. Entre os cristais quadráticos existe material fina mente acicular (natrolita). Muitos dos cristais de mesolita estão parcial ou totalmente alterados. $30 \mathrm{x}$ - Nícois paralelos. 


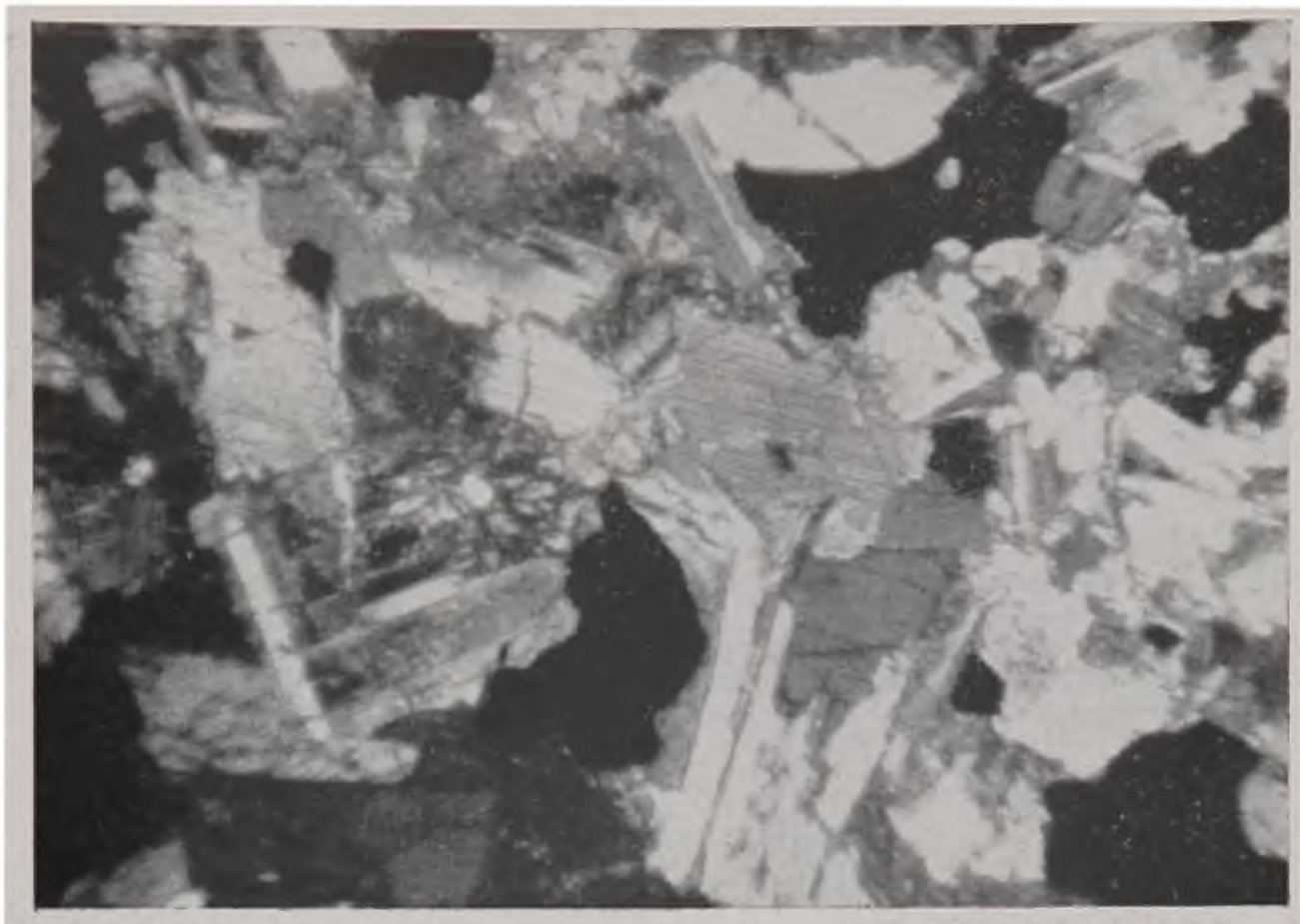

FOTOMICROGRAFIA 3 - Mogi-Guaçu, São Paulo, Lâmina do diabásịc da pedreira defronte a Estaçฐ̃o da Cia. Mogiana de Estrada de Ferro, cujas zonas de cizalhamento estão preenchidas por zeolitas e minerais associados. $30 \mathrm{x}$ Nícois cruzados.

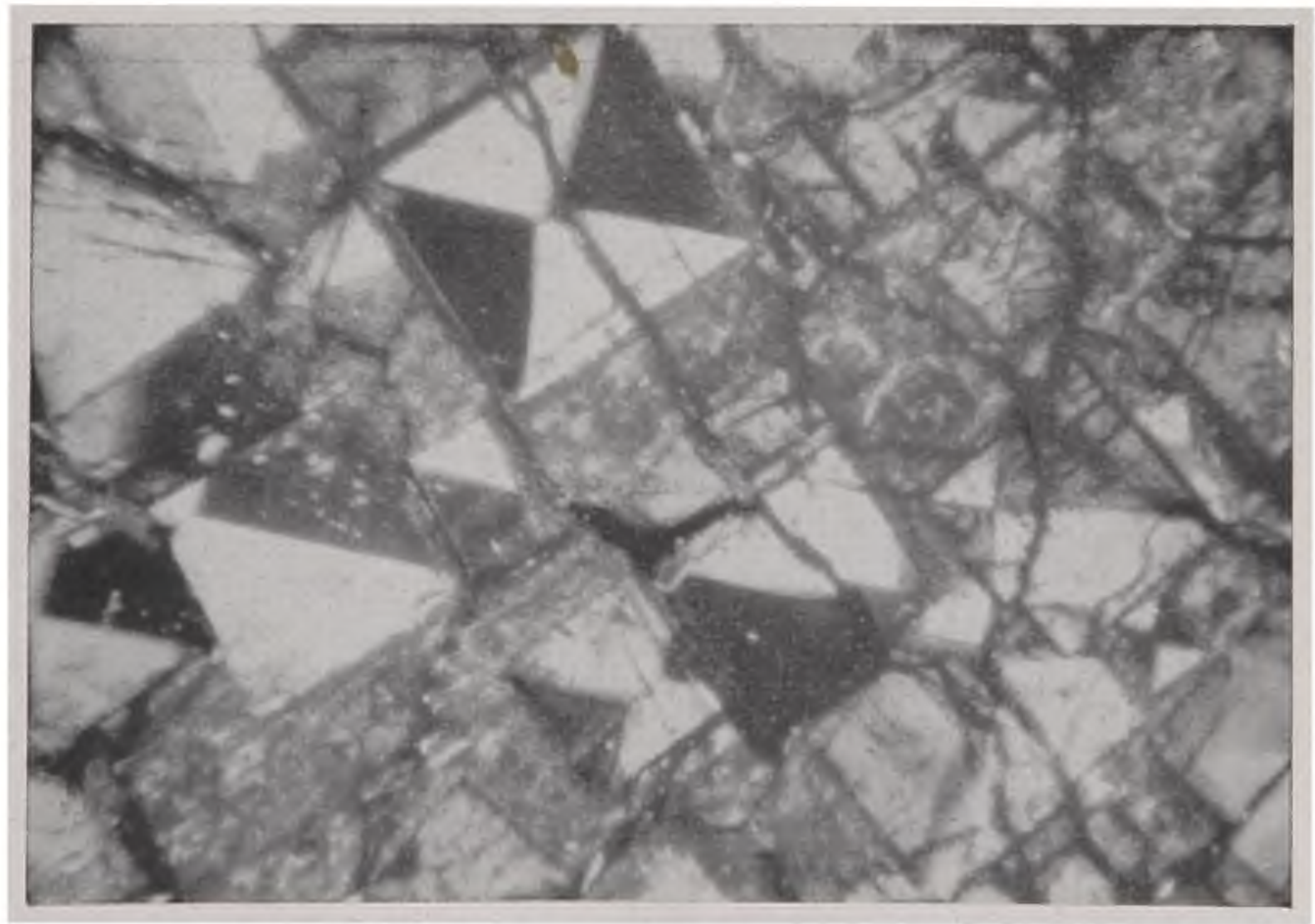

FOTOMICROGRAFIA 4 - Botucatú, São Paulo. Cristais de mesolita crrtados normalmente ao seu alongamento. Notar a clássica geminação, comum a todos os indivíduos, $25 \mathrm{x}-$ Nicois cruzados. 


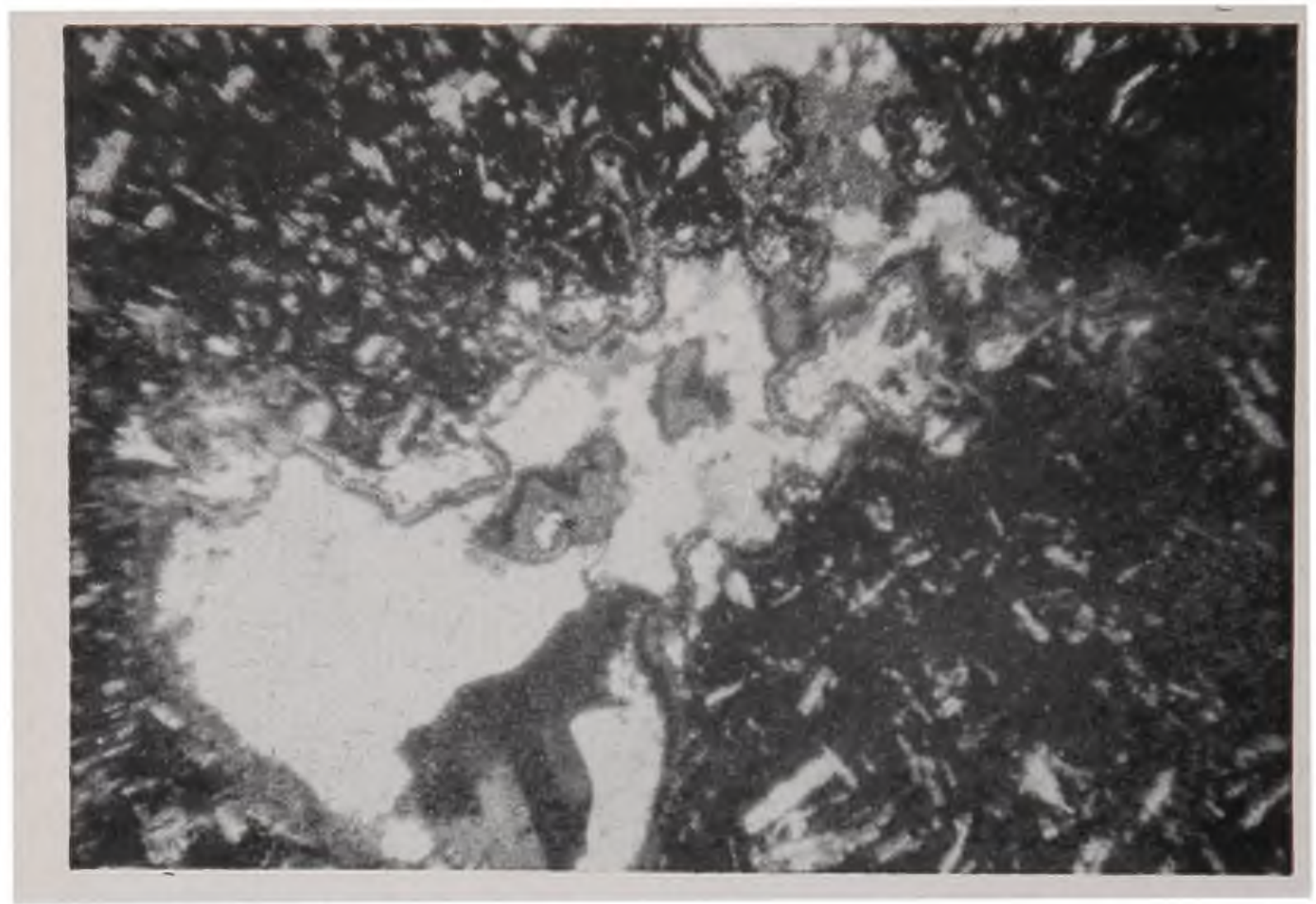

FOTOMICROGRAFIA 5 - Pedreira de basalto do Cascudo, Campo Grands, Mato Grosso. Amigdala irregular no interior do basalto rico de mesostasis vitrea. A amigdala está revestida por um cordão de quartzo. Para o interior encontram-se quartzo (material claro e cinza) e stilbita (material preto e cinza escuro) $25 \mathrm{x}$ Nicois cruzados.

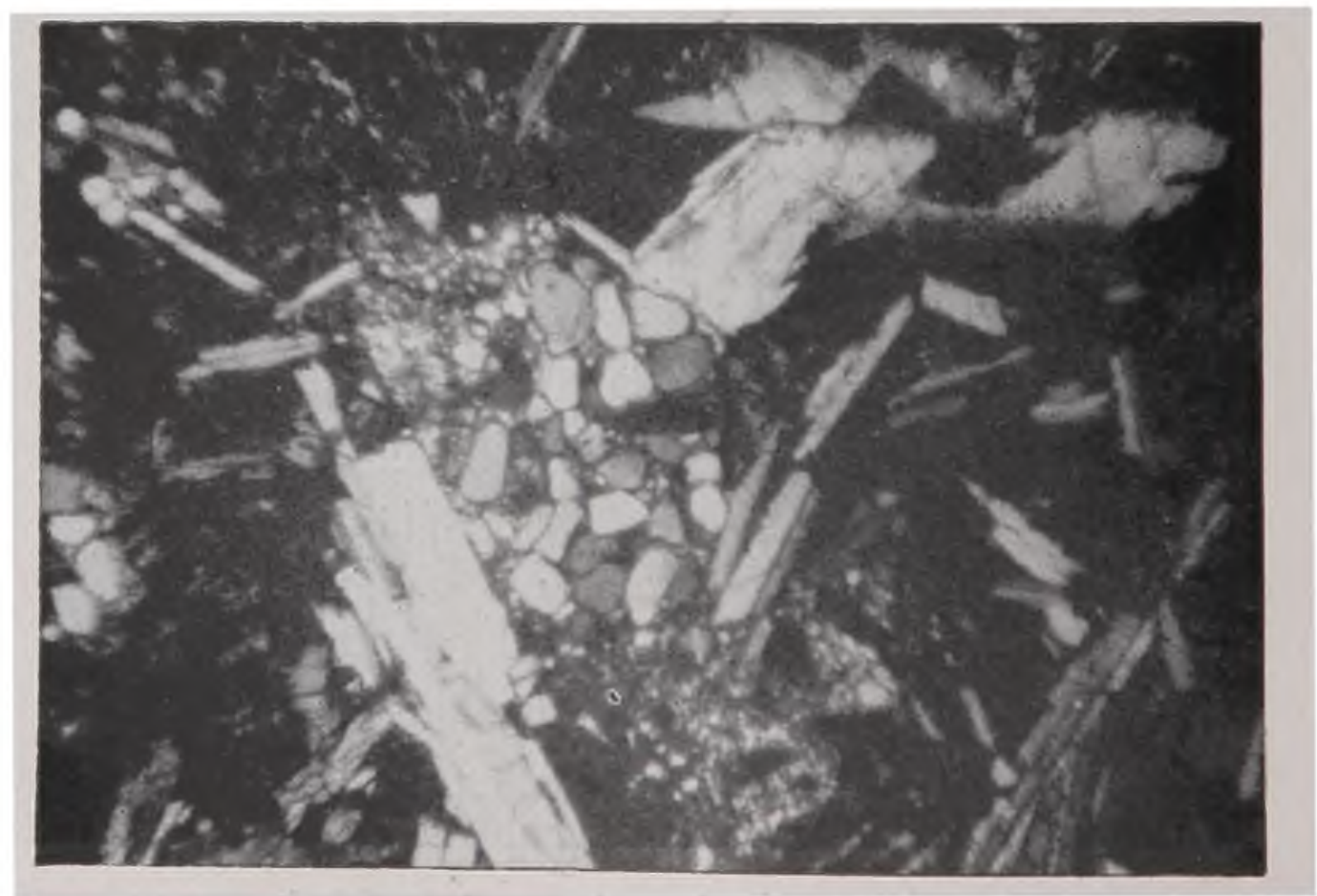

FOTOMICROGRAFIA 6 - Córrego da Manga, Mato Grosso, Fragmento globóide de arenito no interior do basalto rico de mesostasis vítrea. Compare com Fig. 12, no texto. $25 \mathrm{x}$ - Nícois cruzados. 


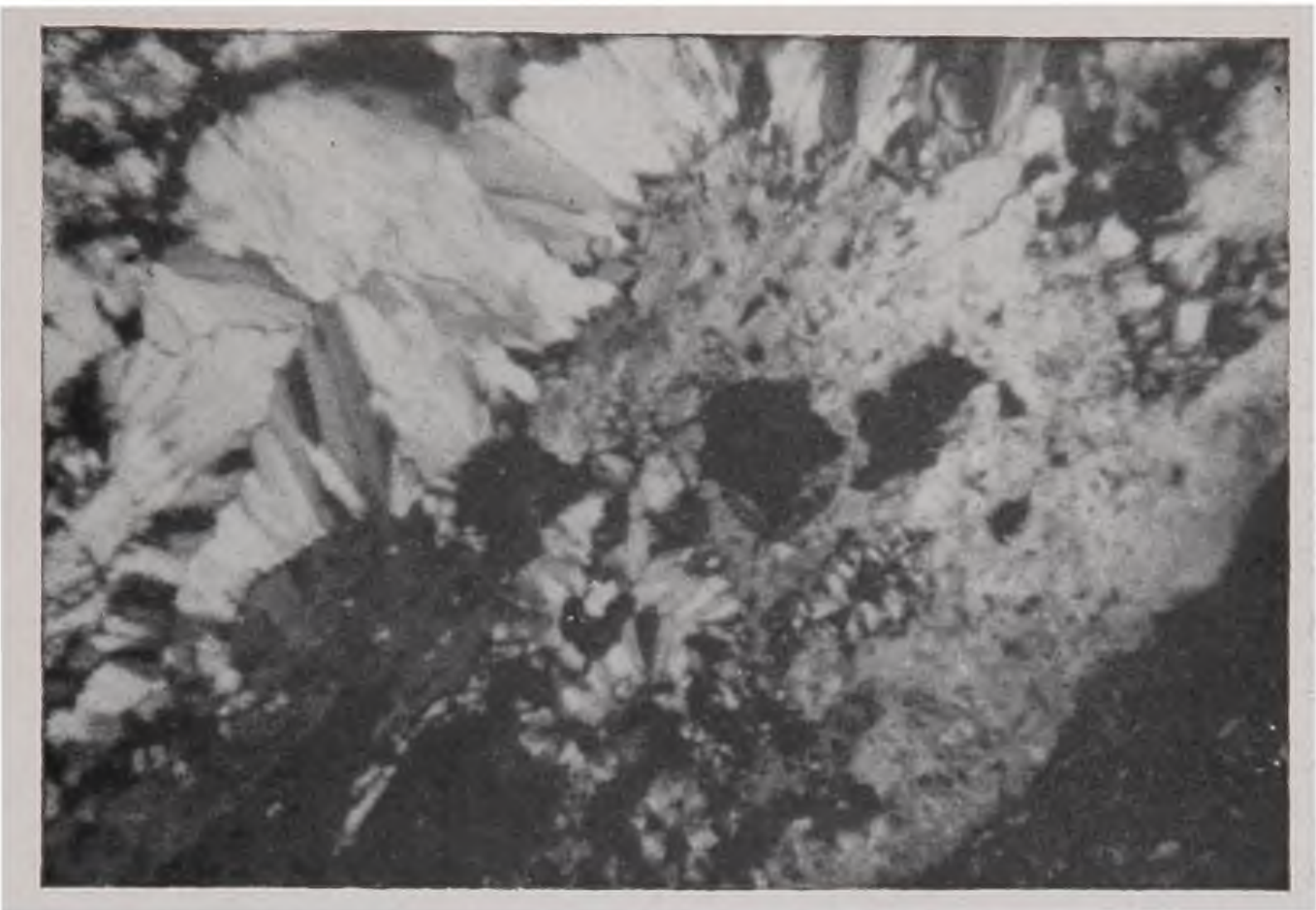

FOTOMICROGRAFIA 7 - Rio Aguapei, Tupan, São Paulo. Basalto rico de mesostasis vitrea. Grande amígdala preenchida por quartzo e stilbita. $30 \mathrm{x}-$ Nicois cruzados.

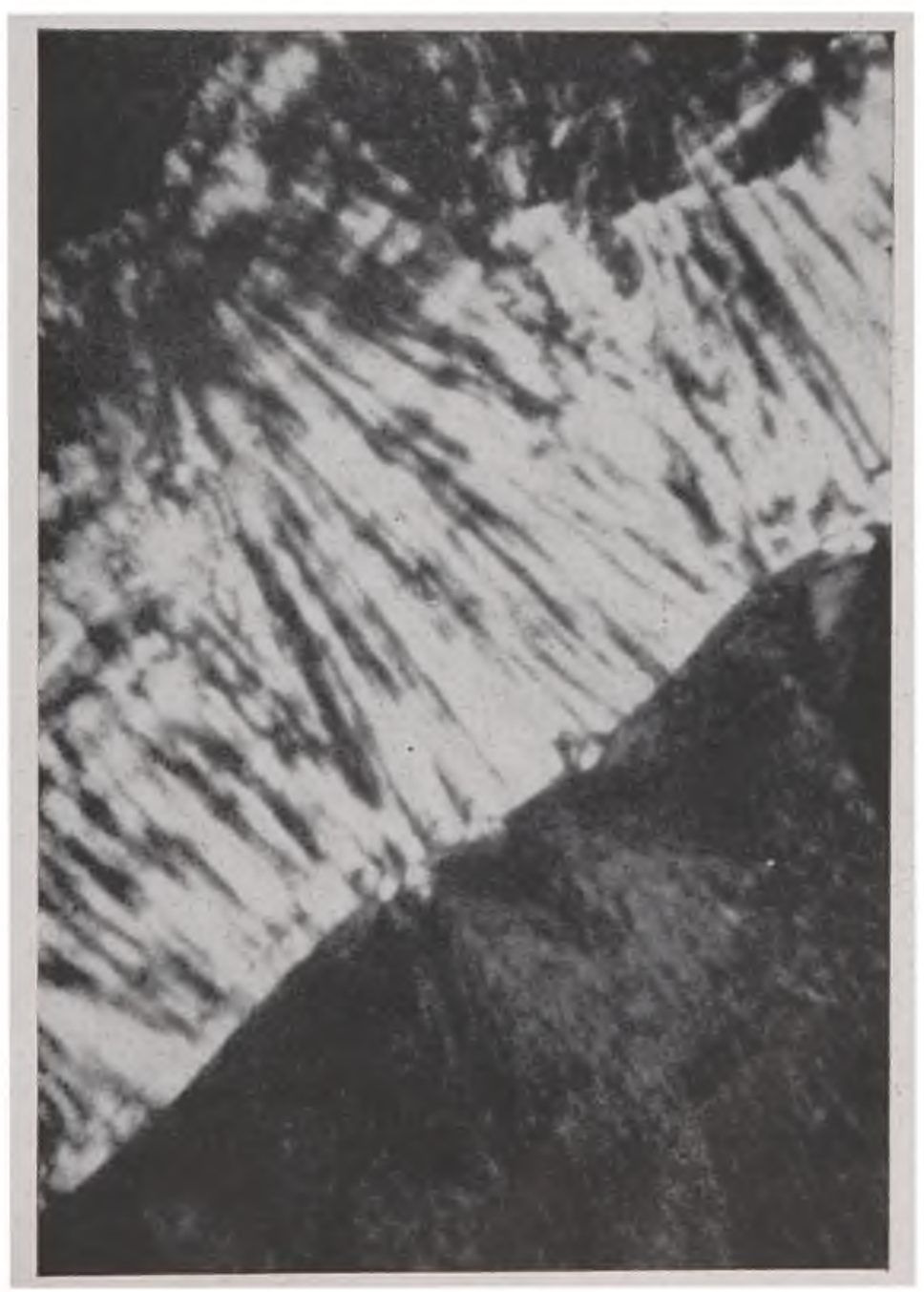

FOTOMICROGRAFIA 8 - São Pedro, São Paulo. Secção delgada em material de preenchimento de uma amígdala. Duas variedades de calcedônia. $30 \mathrm{x}-$ Nícois cruzados. 


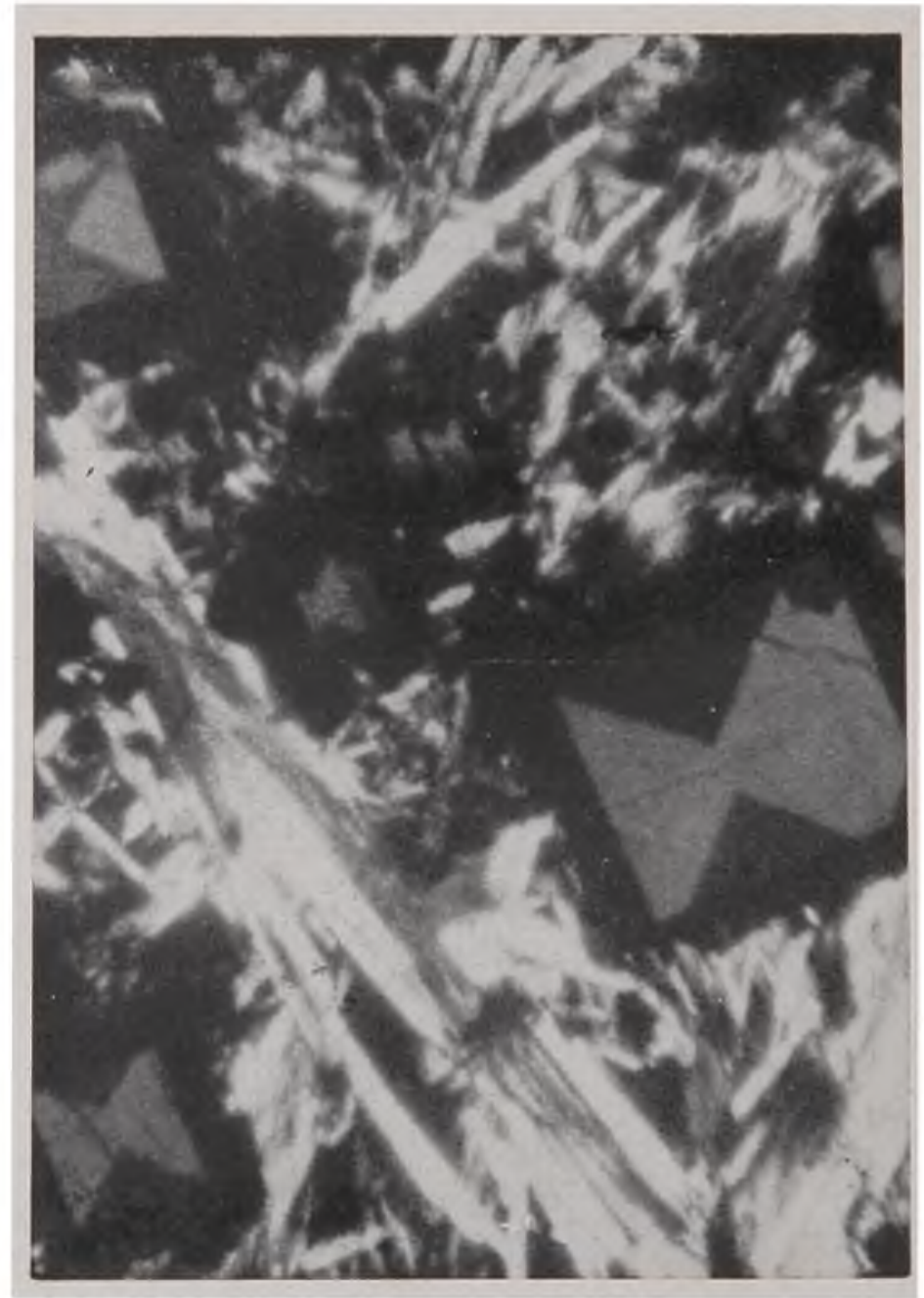

FOTOMICROGRAFIA 9 - Torrinha, São Paulo. Cristais de mesolita geminada entre agulhas de natrolita e thomsonita. $62 \mathrm{X}$ - Nicois Cruzados. 


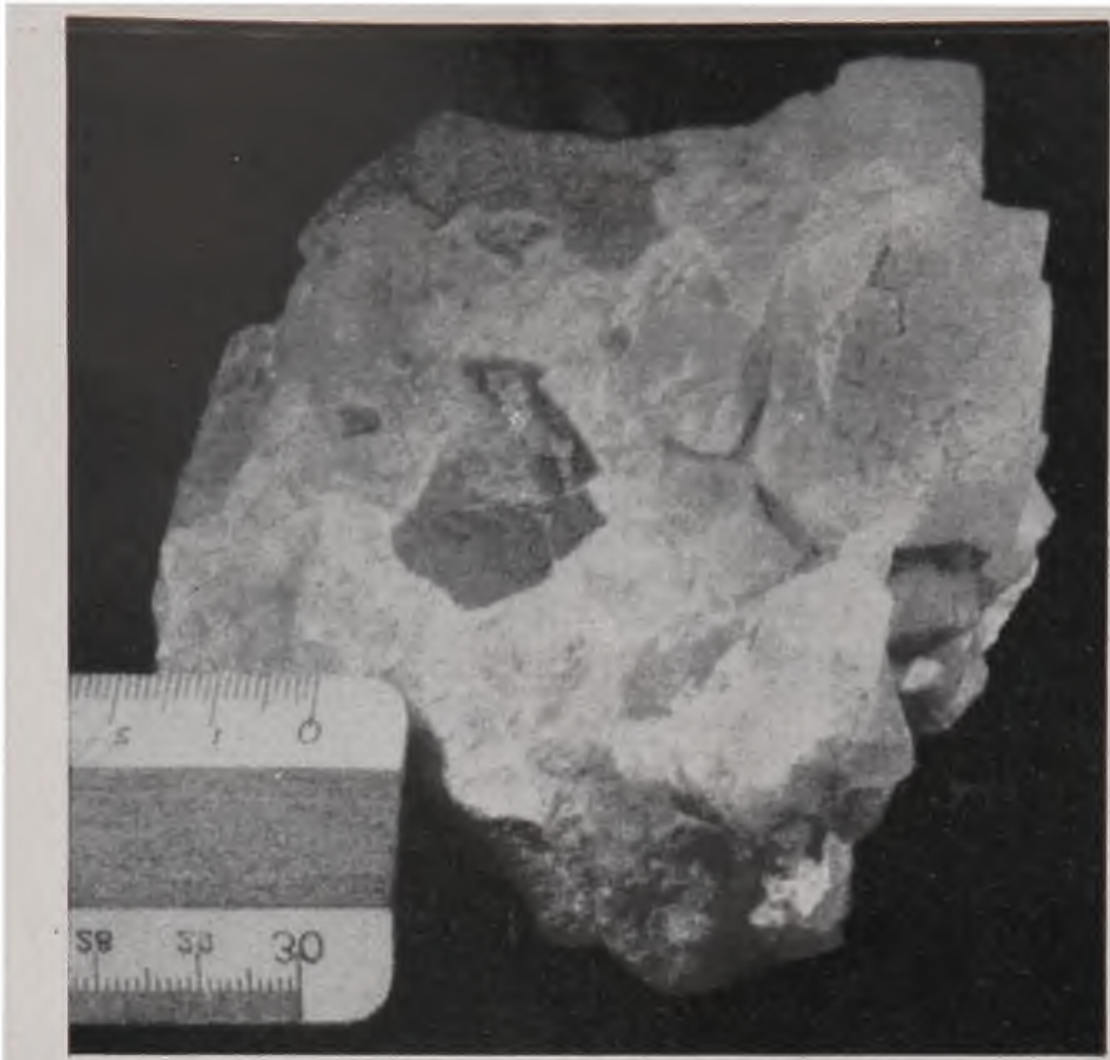

FOTOGRAFIA 1 - Nova Veneza, Santa Catarina, Grandes cristais de apofilita verde englobando um pedaço de basalto.

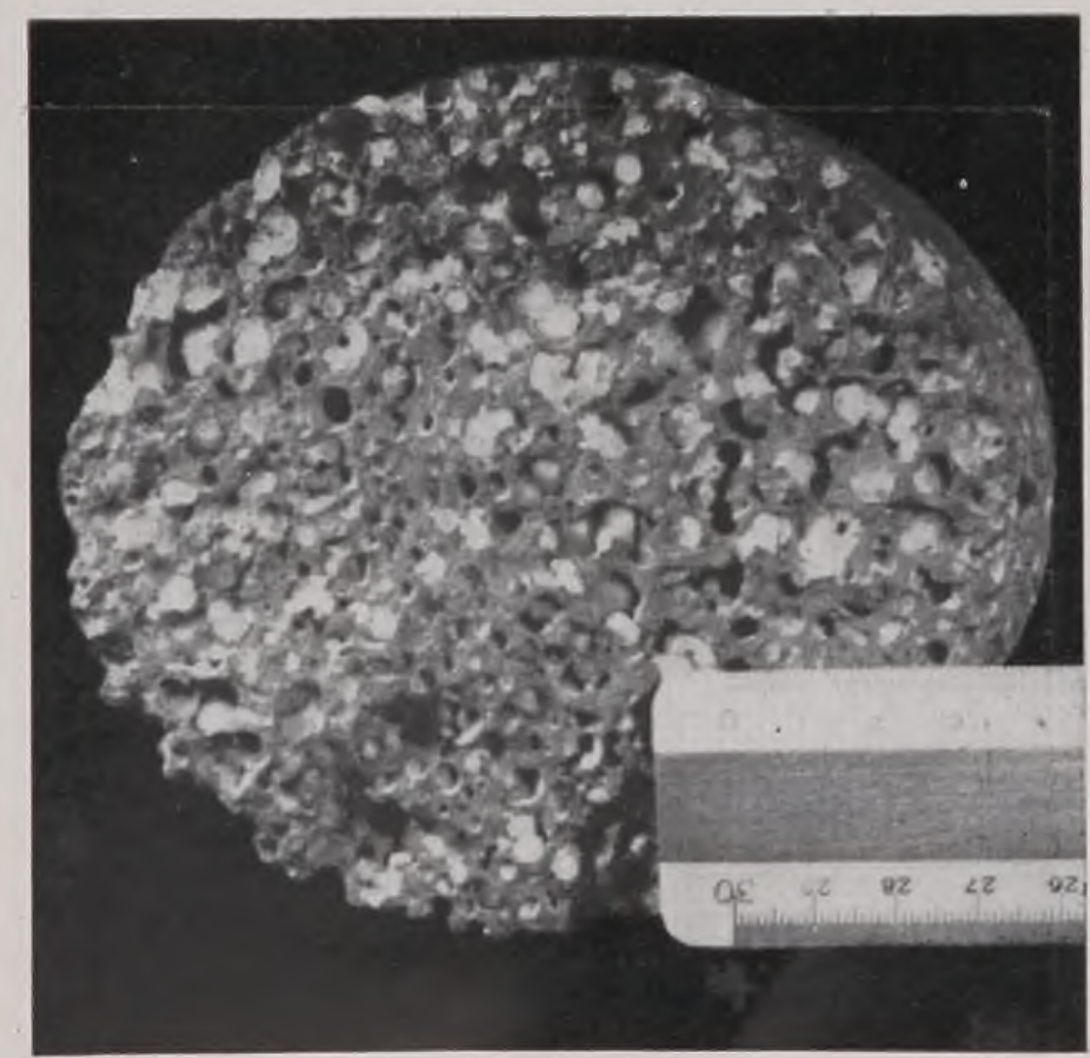

FOTOGRAFIA 2 - Lins, São Paulo. Basalto vesículo anigdaloidal preenchido exclusivamente por analcita. 


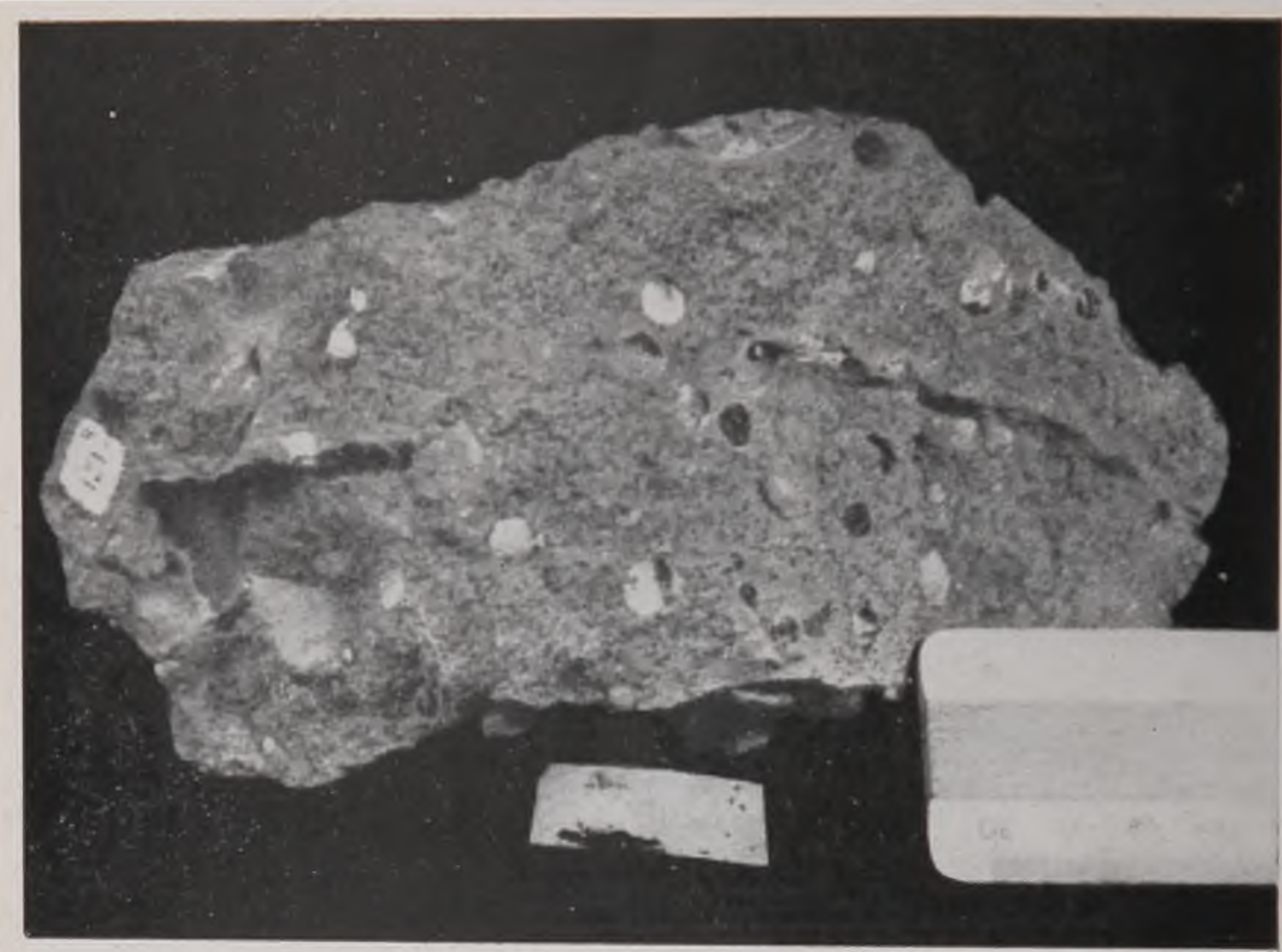

FOTOGRAFIA 3 - Basalto da barragem da Empresa de Eletricidade Vale do Paranapanema S. A., proximidades de Assis, São Paulo. Notar vesículas preenchidas por calcedónia (material claro) e daohnita (material escuro).

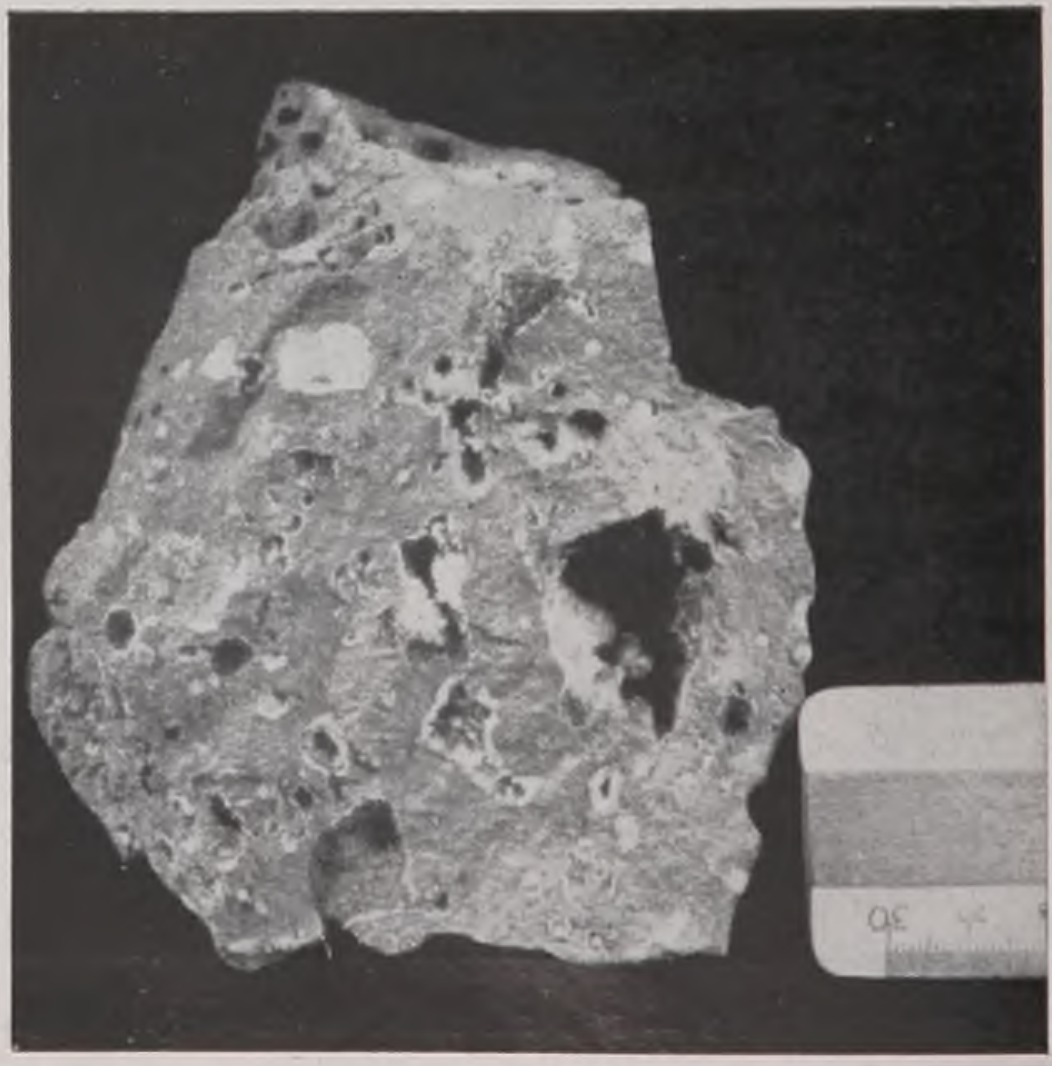

FOTOGRAFIA 4 - Basalto da barragem da Emprésa de Eletricidade Vale Paranapanema S. A., proximidades de Assis, São Paulo. Basalto vesículo-amigdaloidal. Notar a forma irregular das amígdalas e vesículas. 


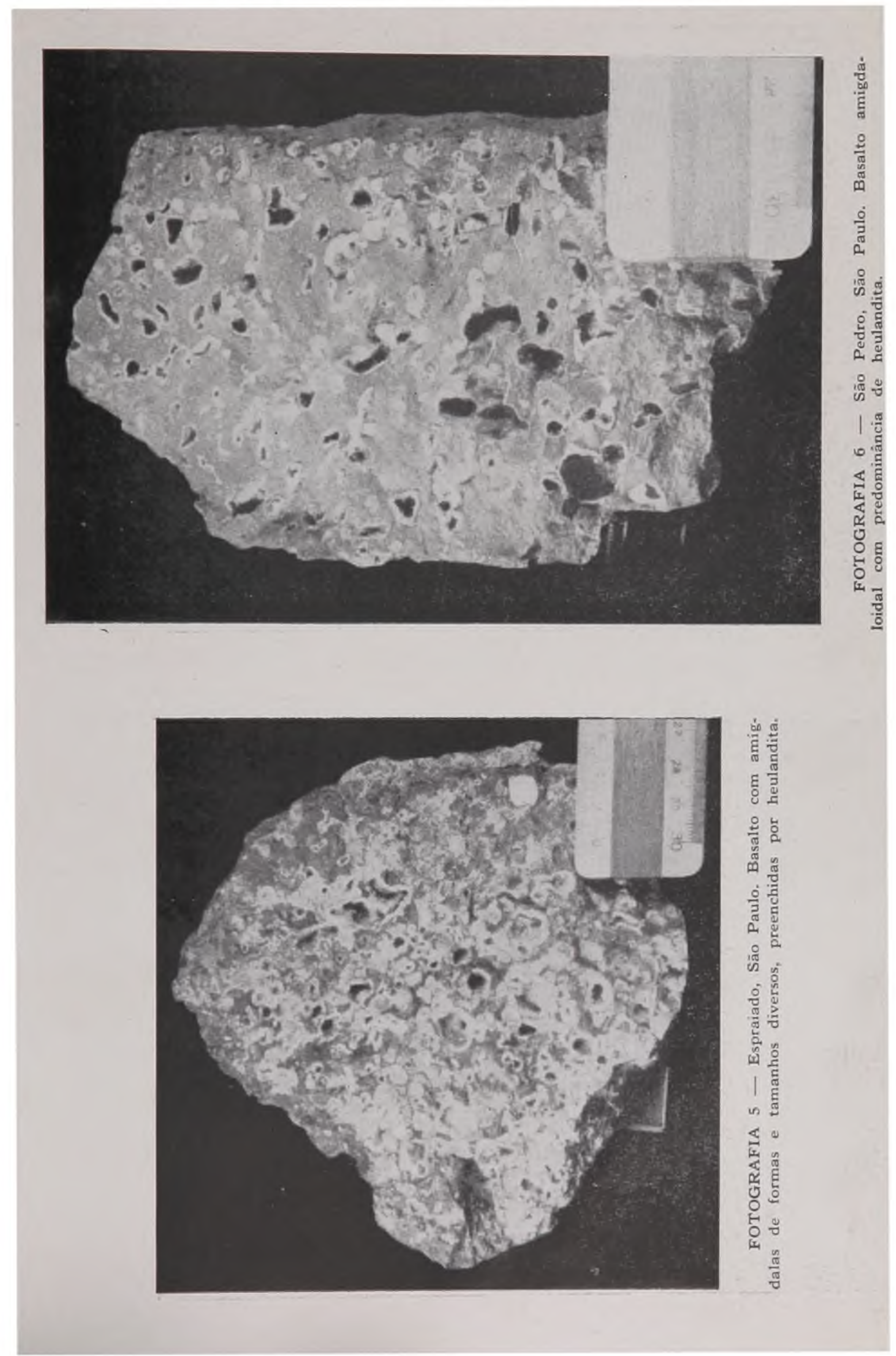



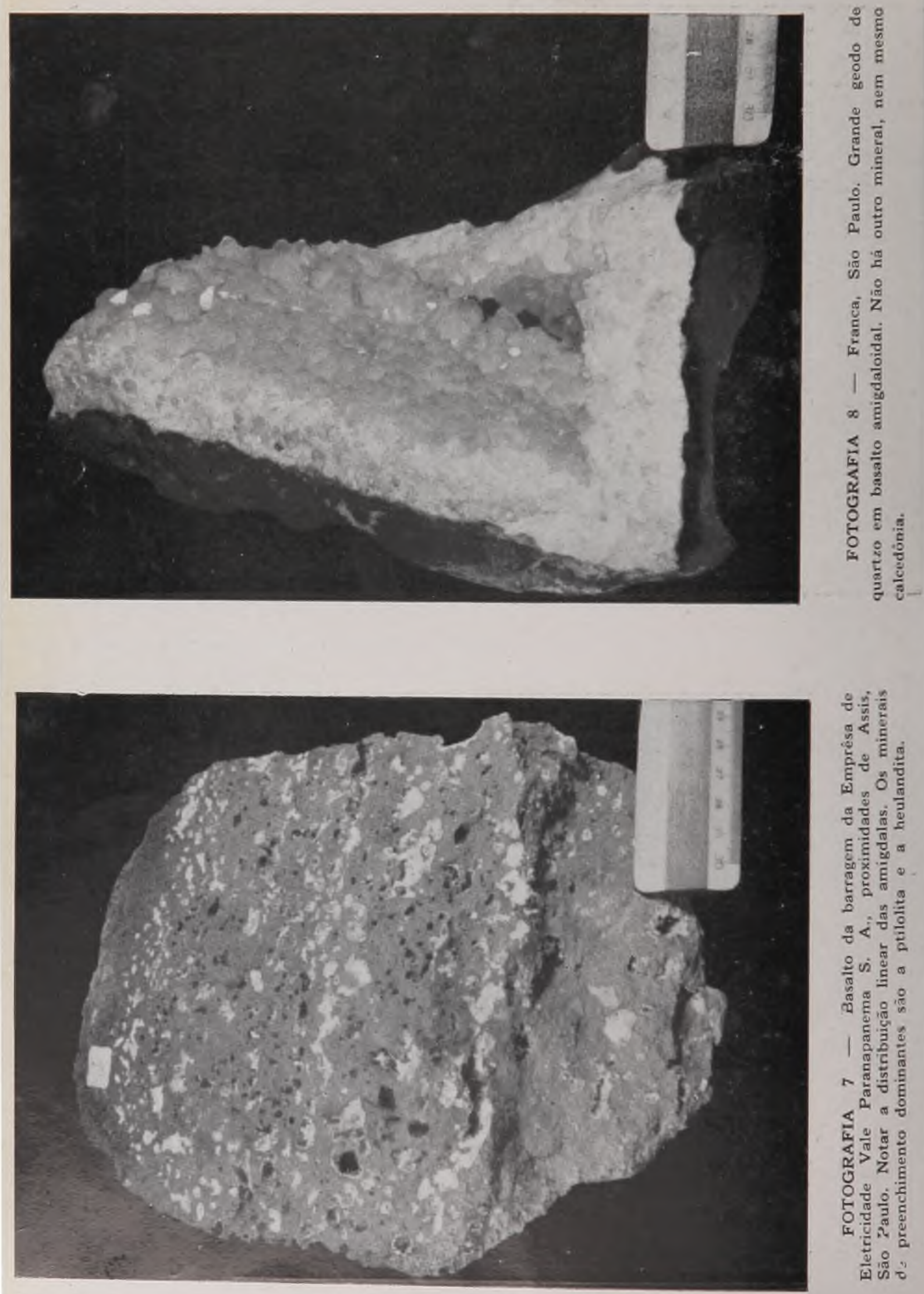

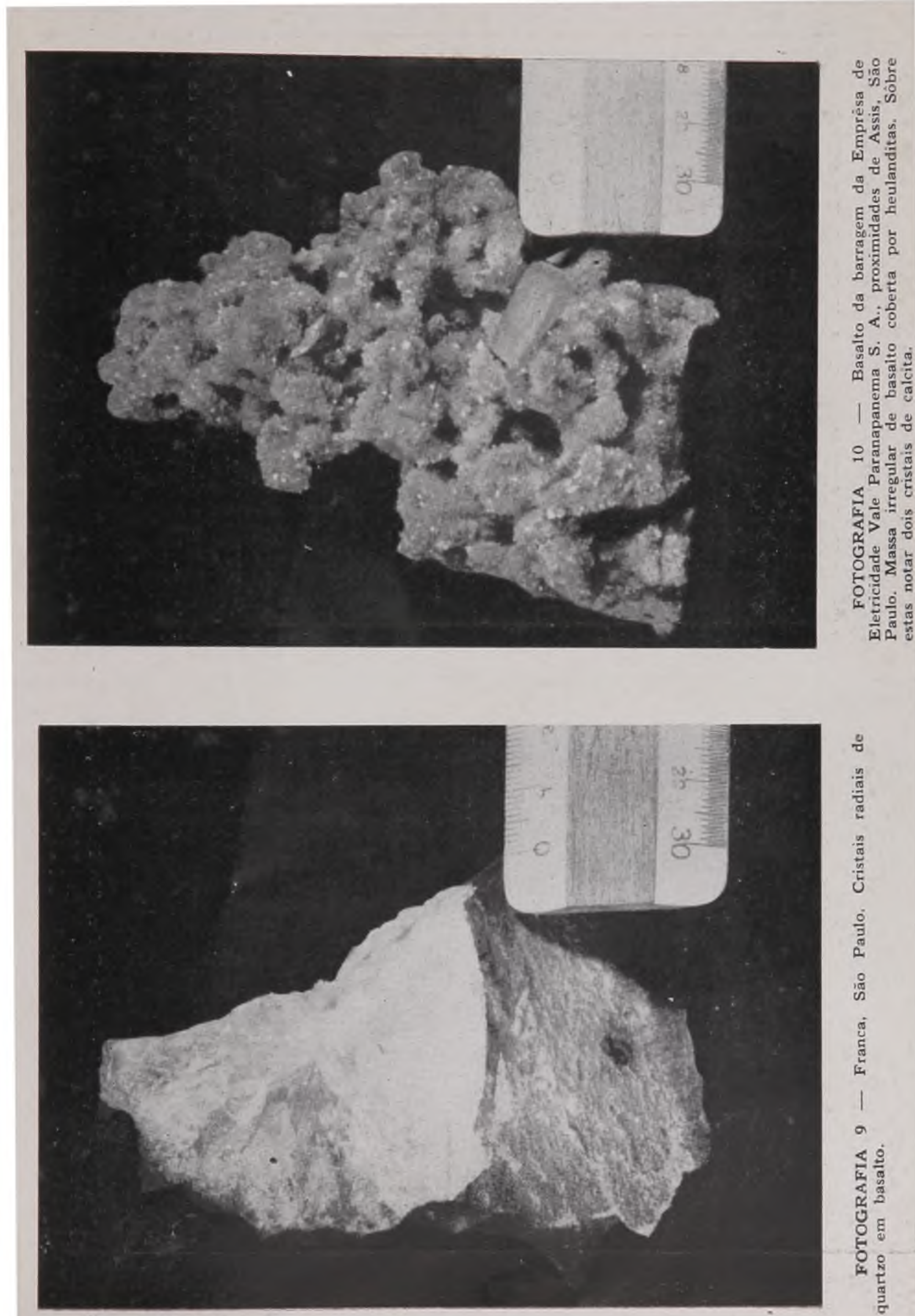

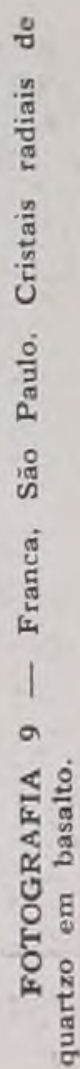




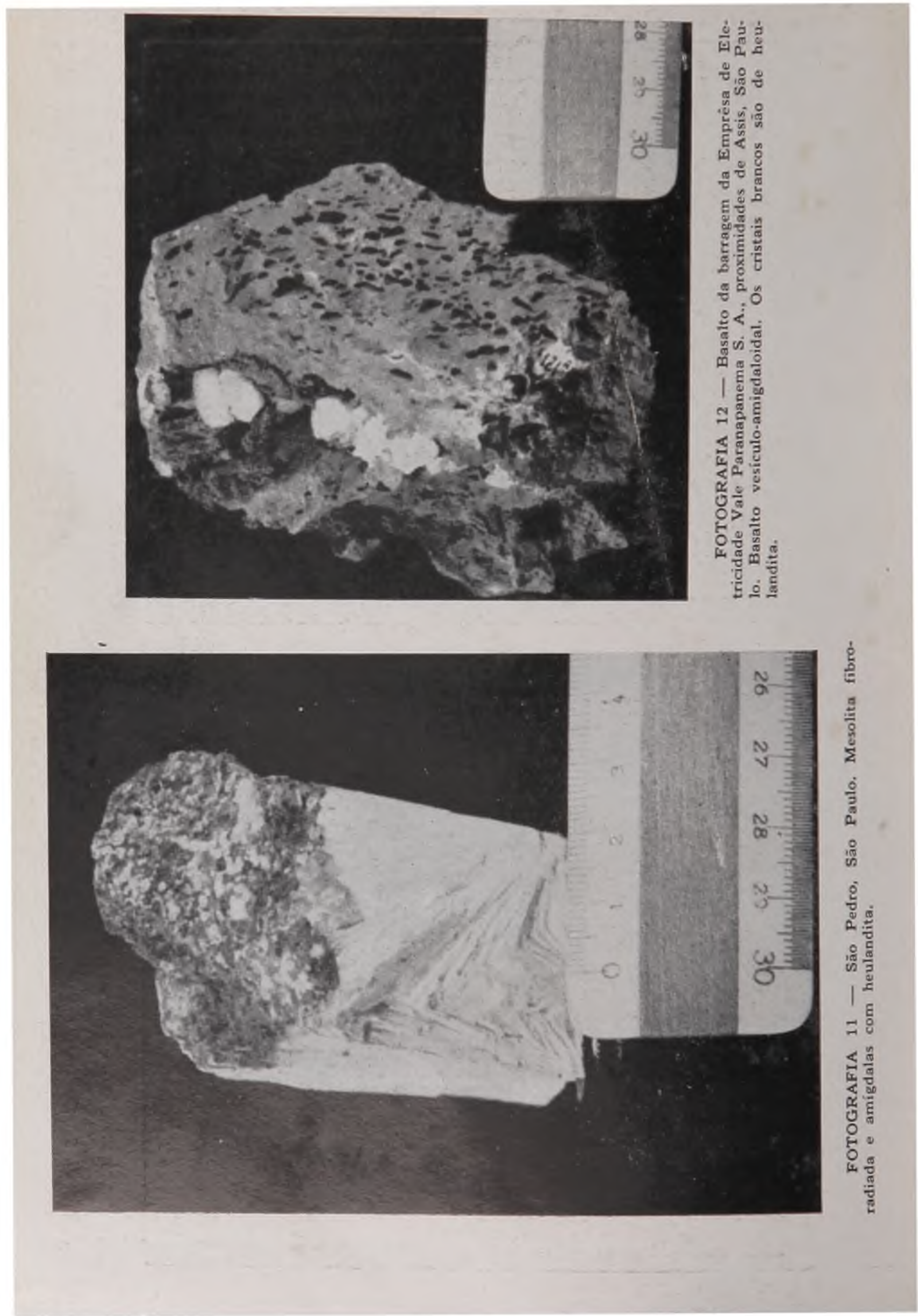



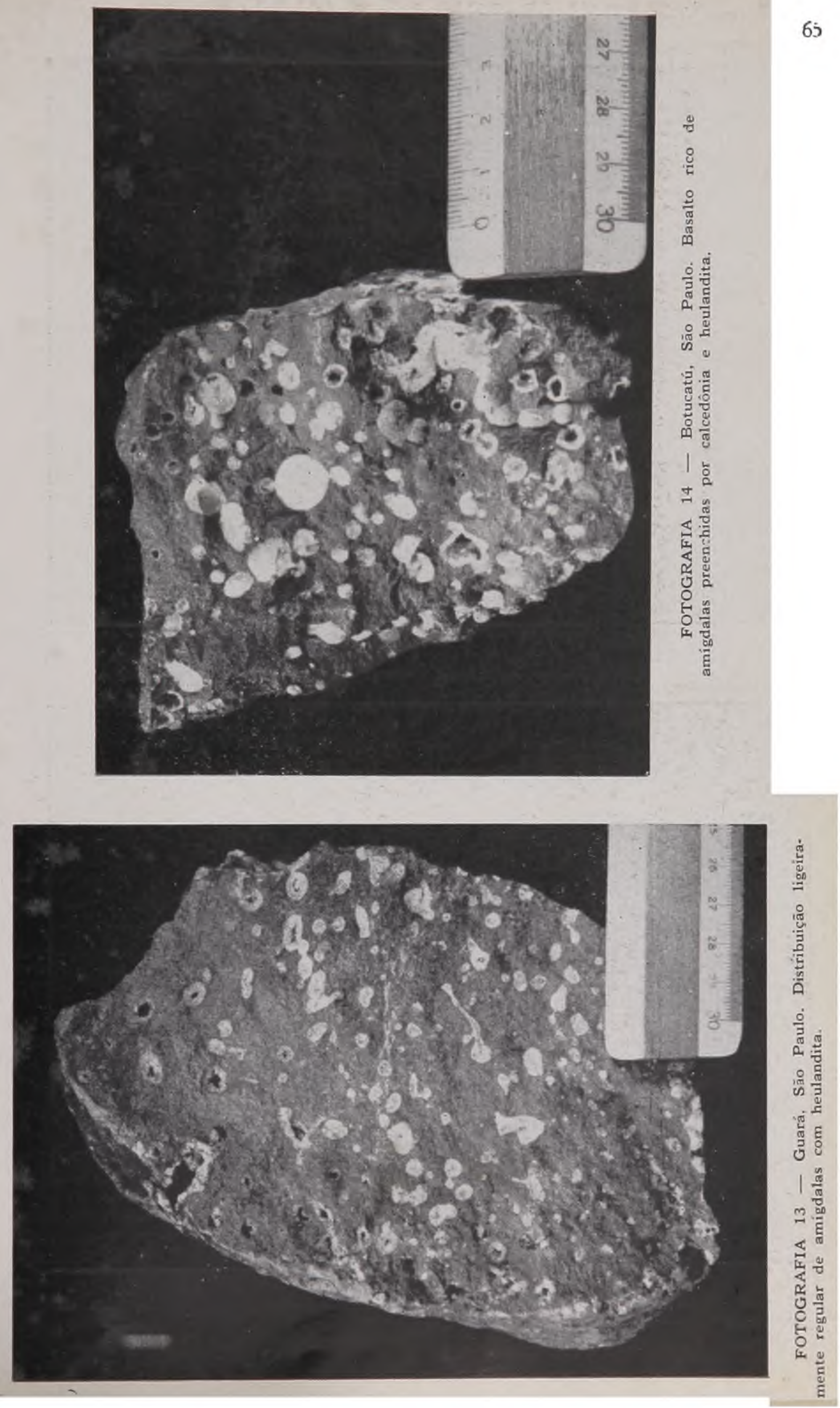


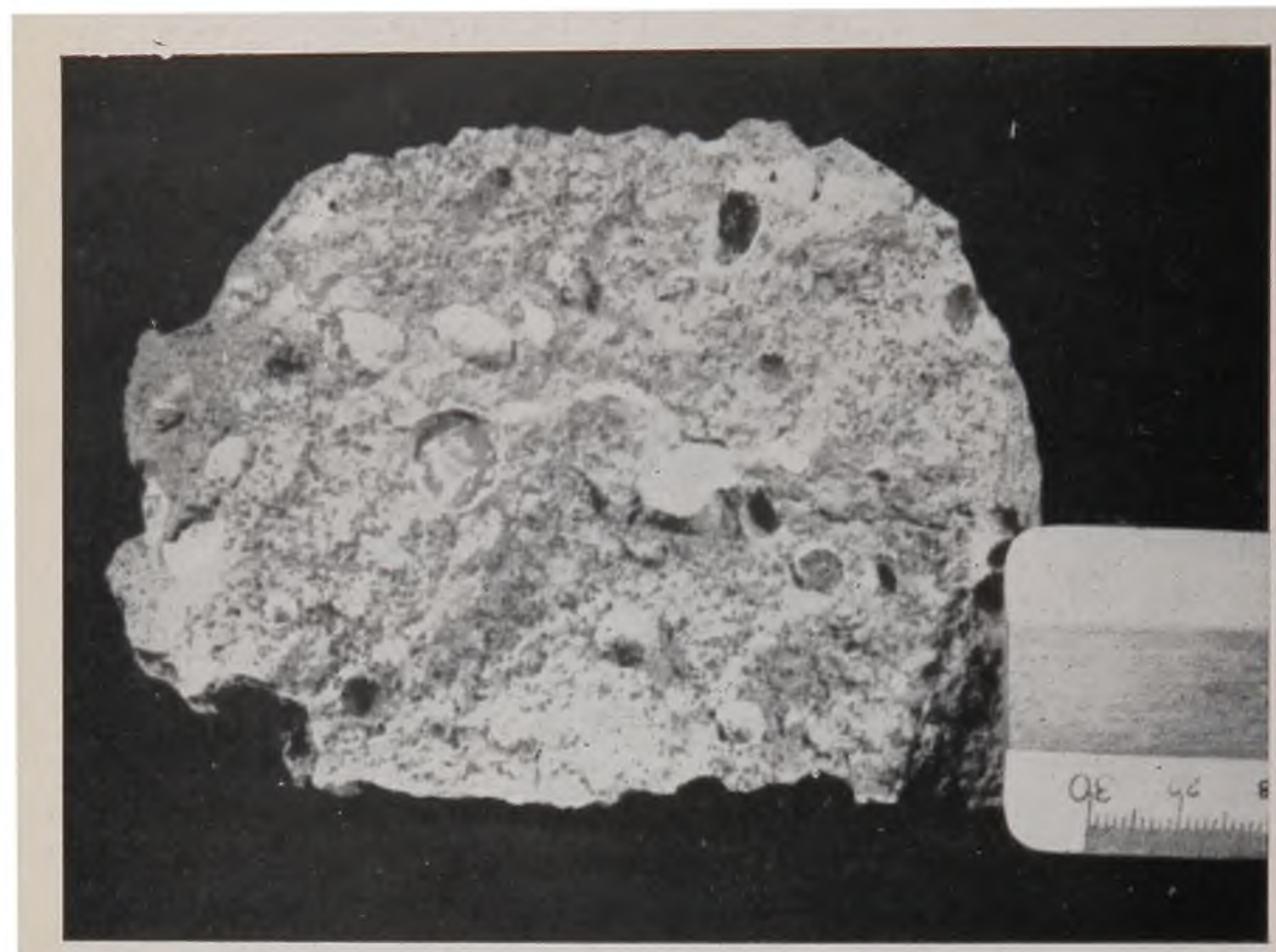

FOTOGRAFIA 15 - Basalto da barragem da Emprêsa Vale Paranapanema S. A. proximidades de Assis, São Paulo. Amígdalas com calcedônia, heulandita e daphnita,

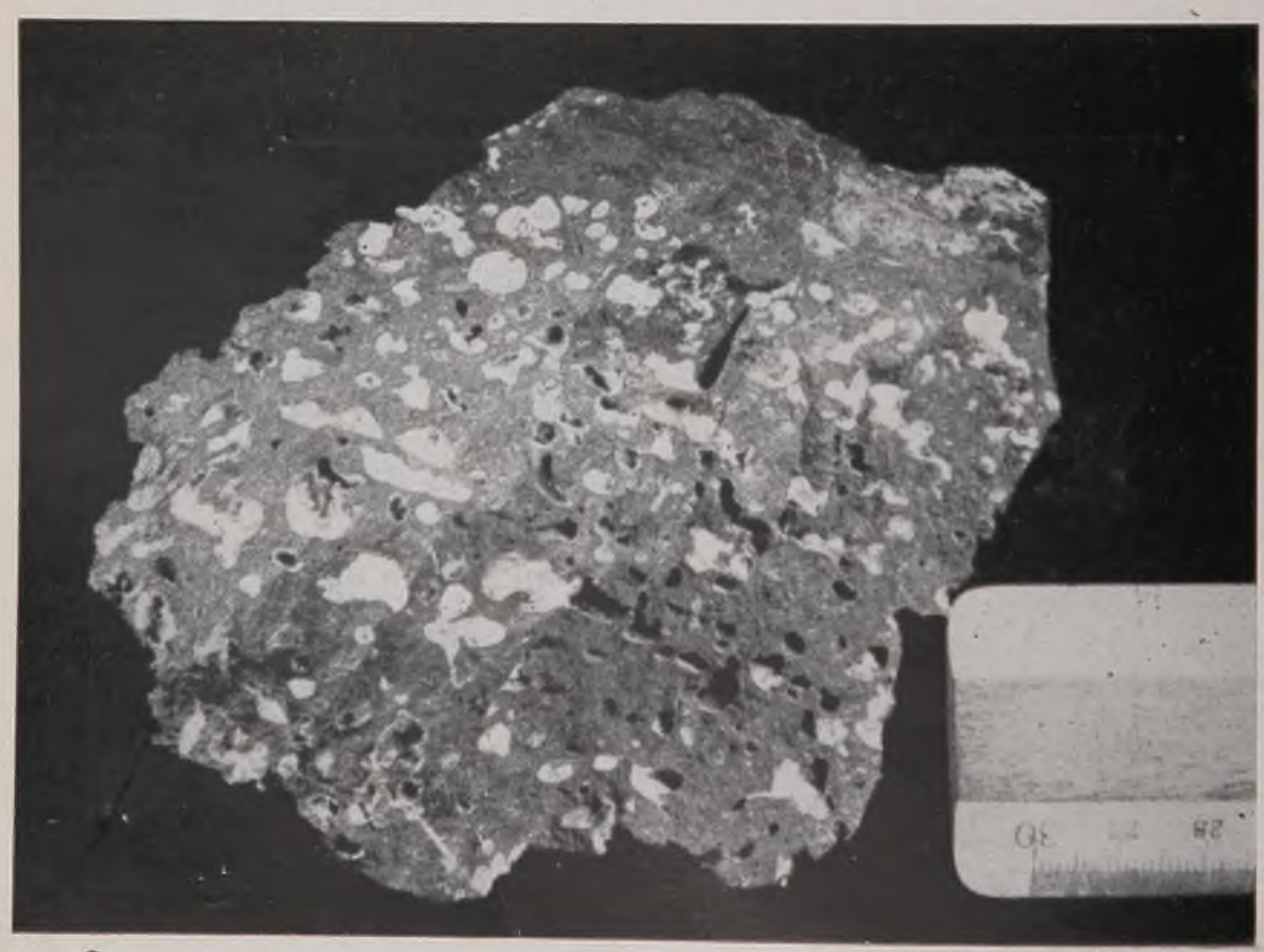

FOTOGRAFIA 16 - Serra da Esperança, Paraná. Basalto amigdaloidal rico de quartzo e calcedônia. 


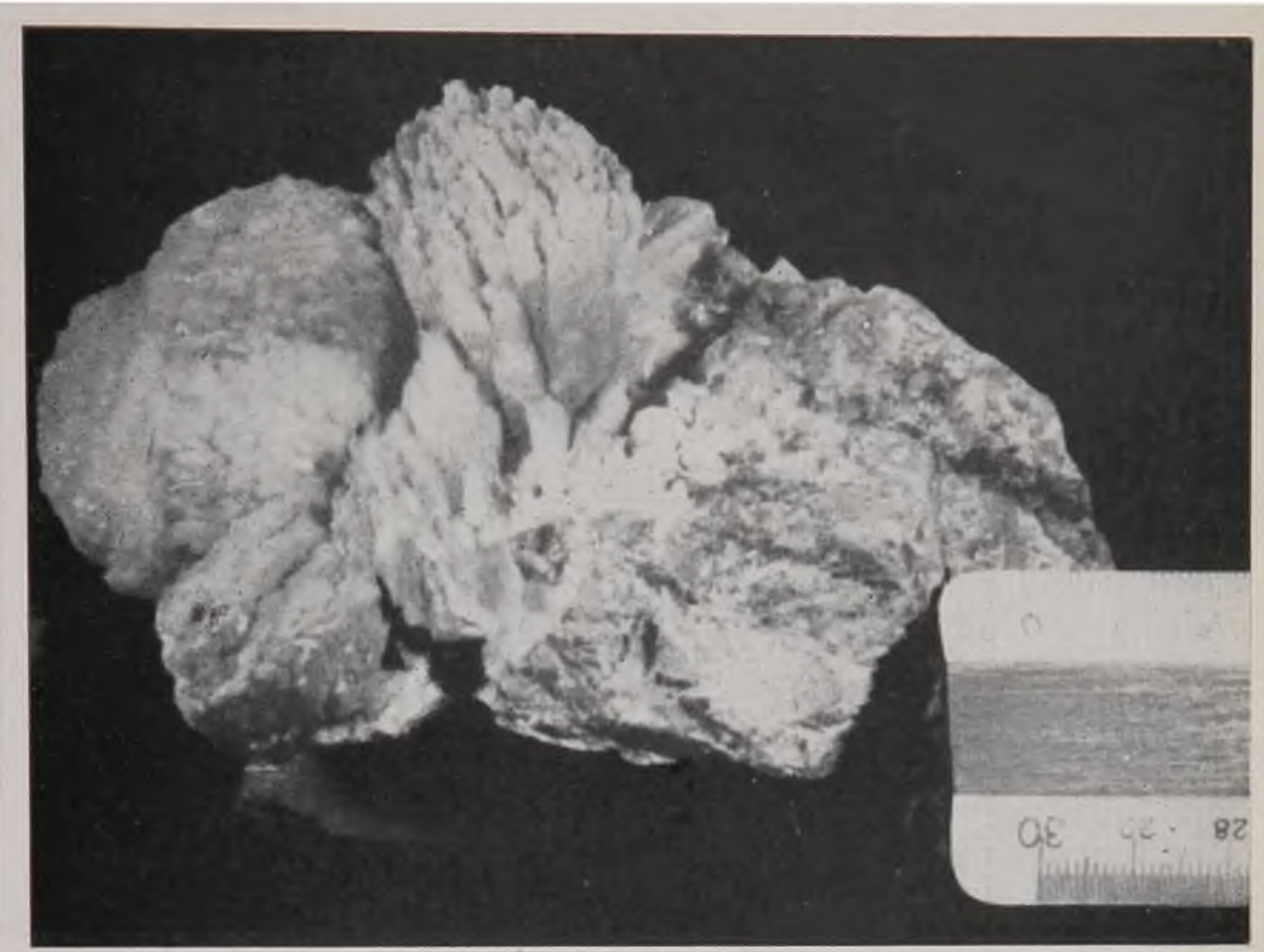

FOTOGRAFIA 17 - Brotas, São Paulo. Grandes massas de cristais de stilbita.

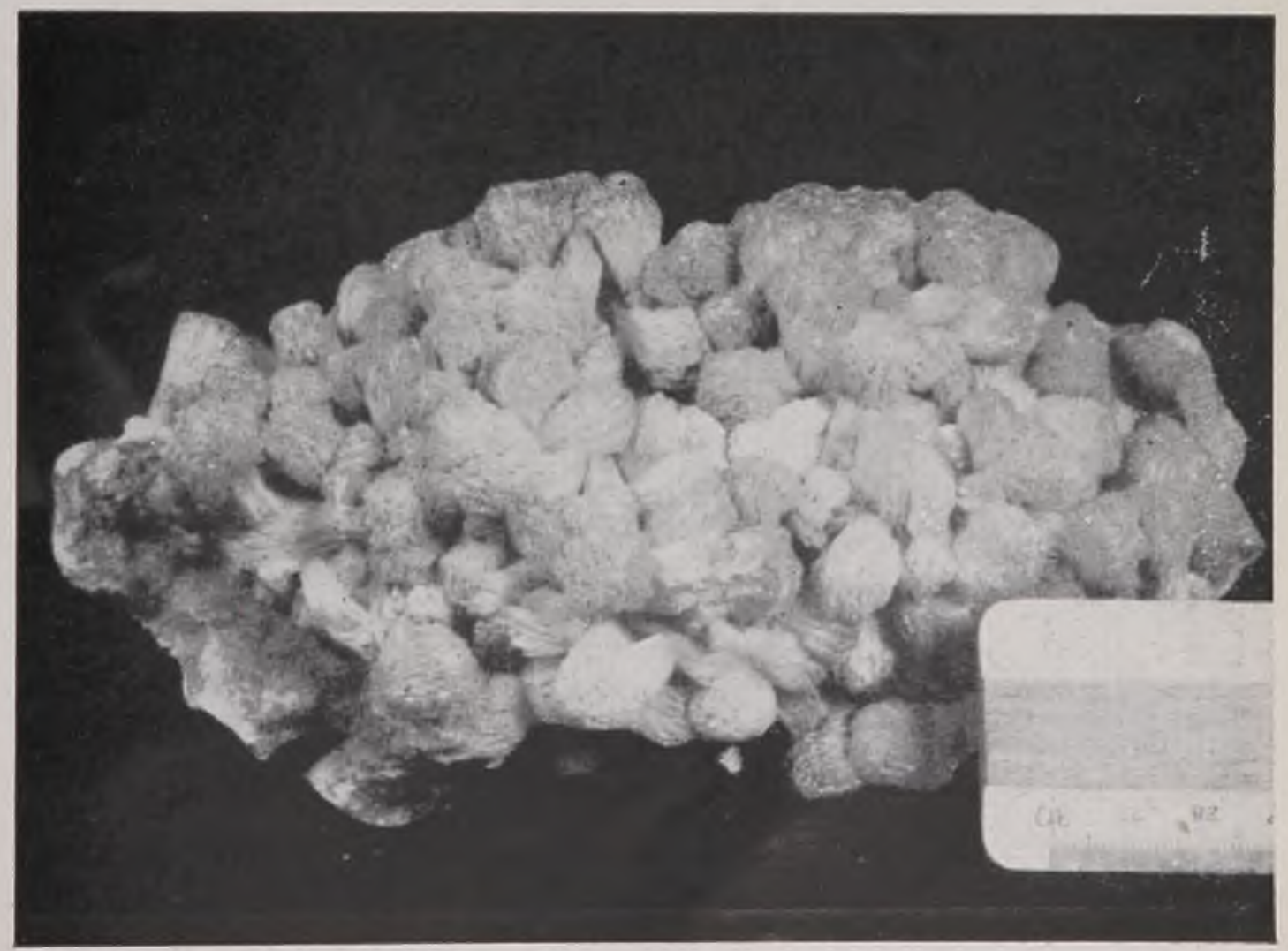

FOTOGRAFIA 18 - Brotas, São Paulo. Belissimos cristais de stilbita. 


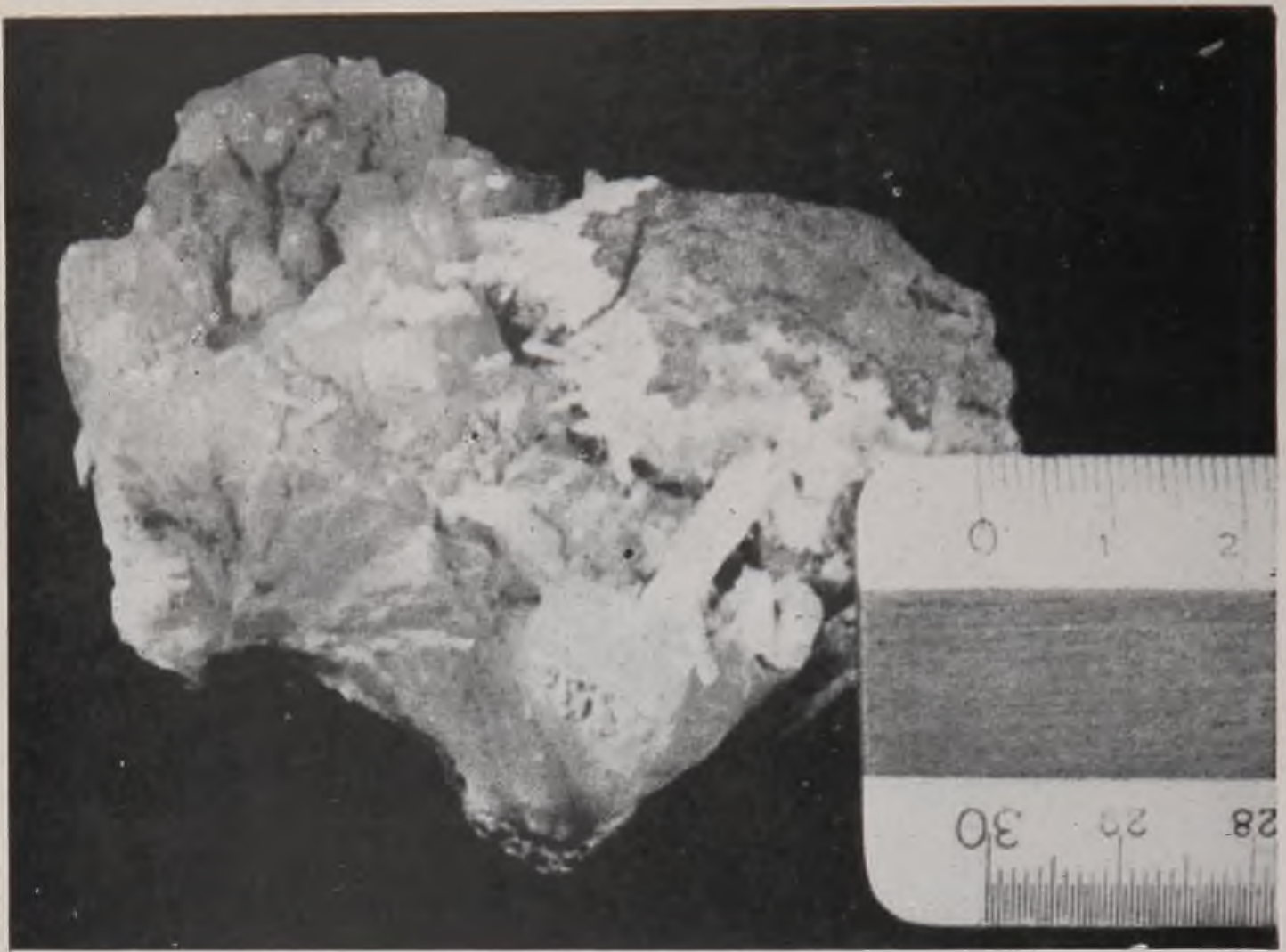

FOTOGRAFIA 19 - Brotas, São Paulo. Cristais de stilbita, em arenito enciurecido.

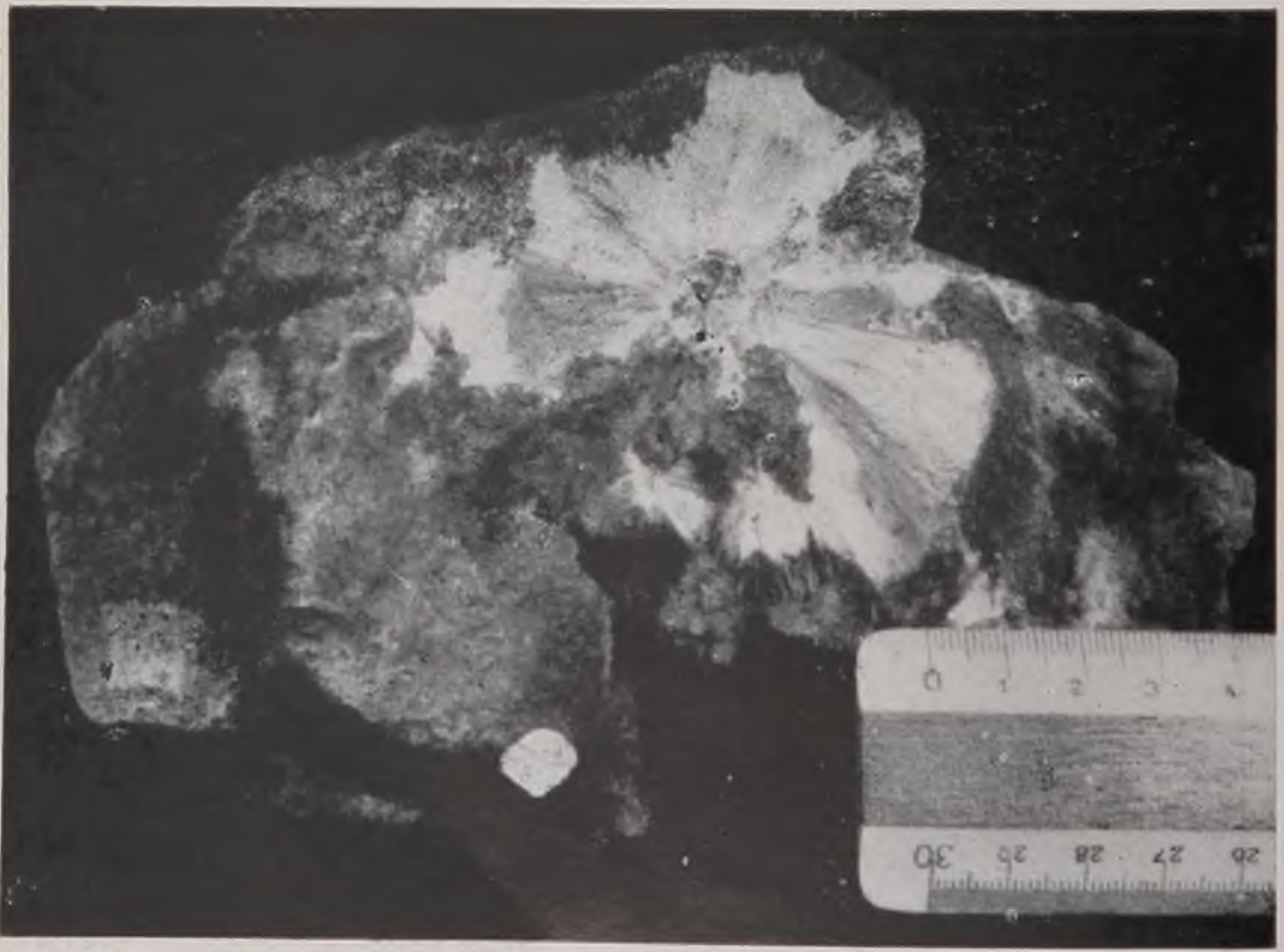

FOTOGRAFIA 20 - Botucatú, São Paulo. Mesolita (material branco) em basalto vesículo-amigdaloidal, rico de heulandita. 


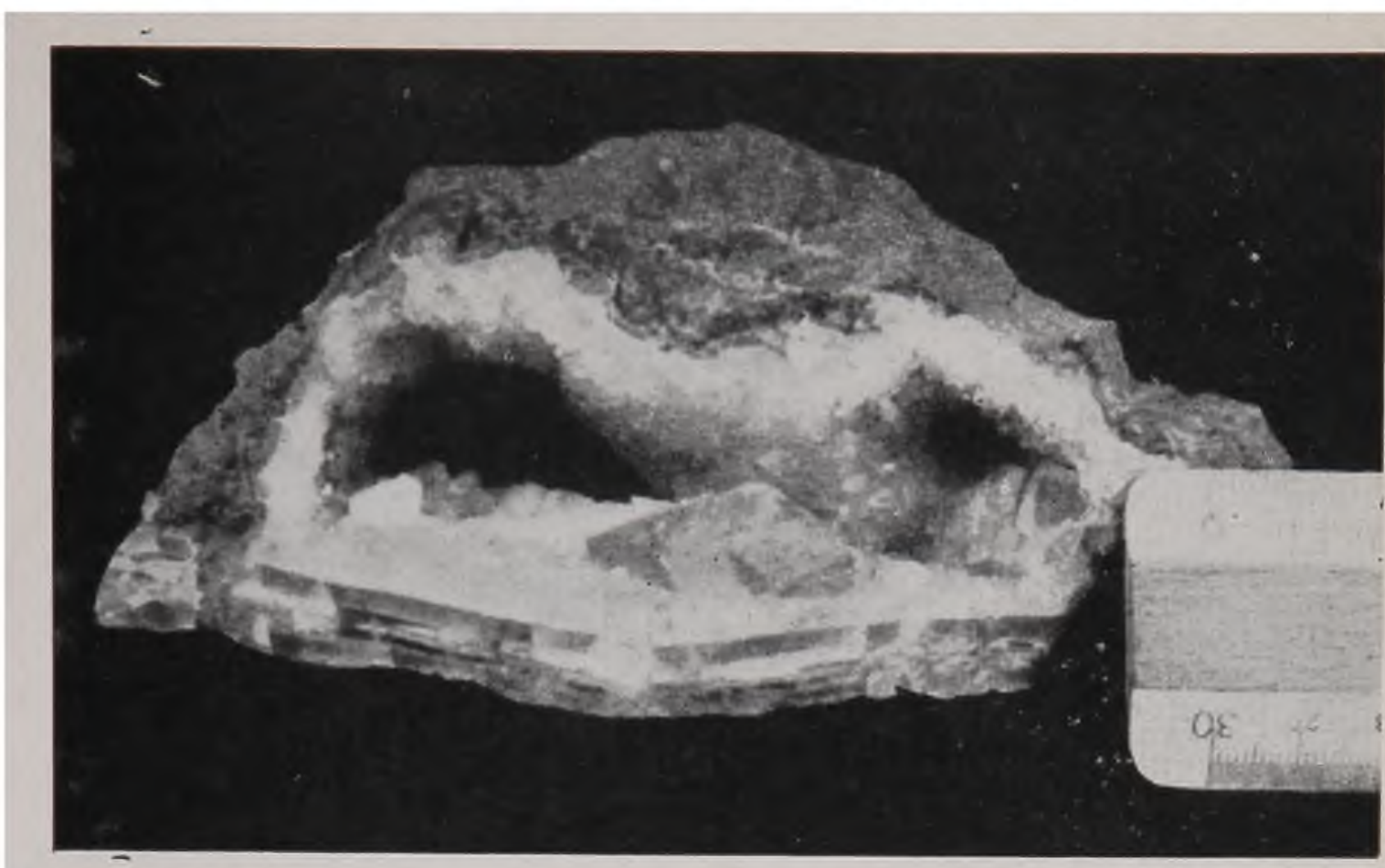

FOTOGRAFIA 21 - Basalto da barragem da Emprêsa de Eletricidade Vale Paranapanema S. A., proximidades de Assis, São Paulo. Comparar esta fotografia com a Fig. 14, no texto.

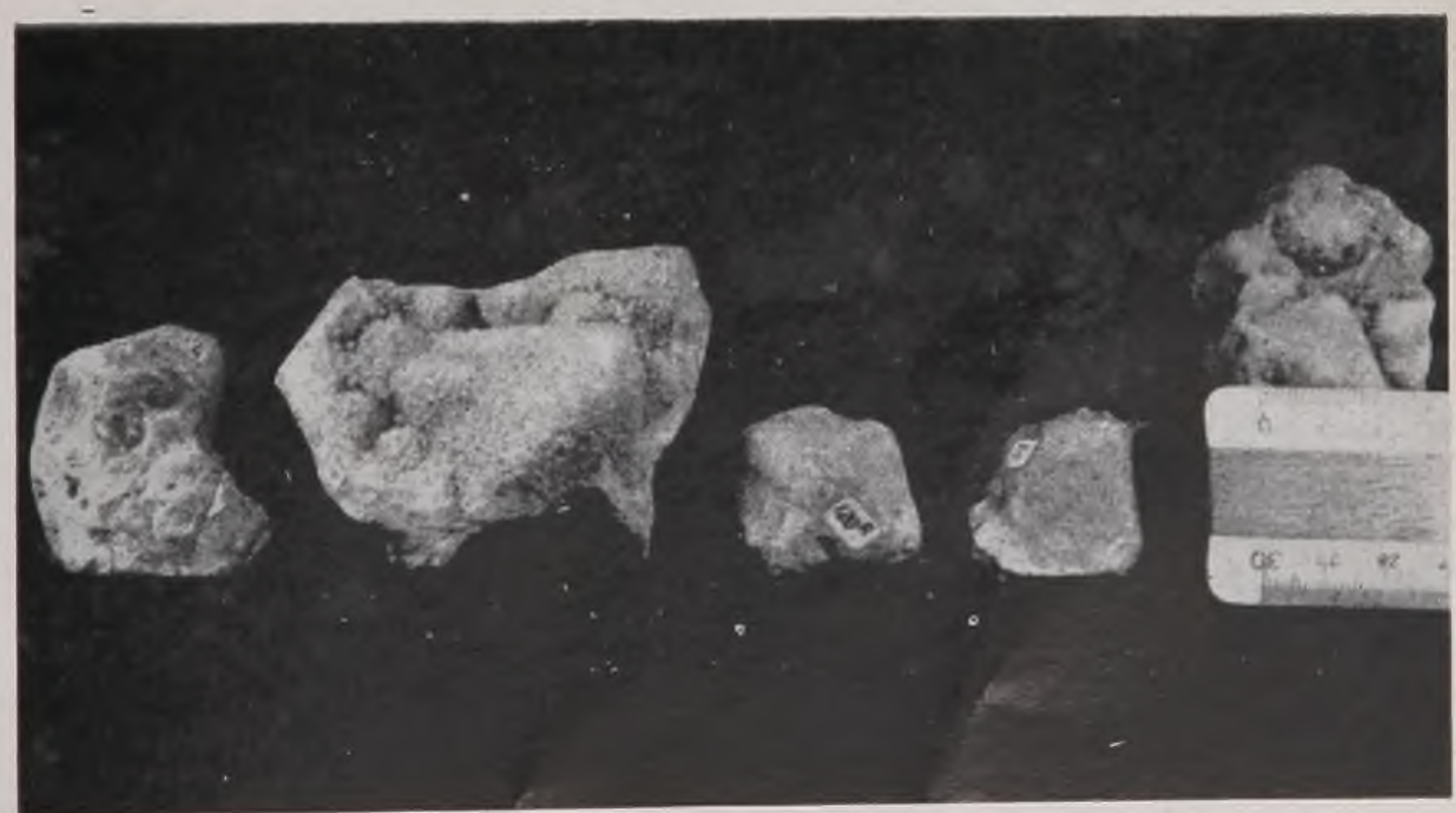

FOTOGRAFIA 22 - Fazenda do Mioto, Araraquara, São Paulo. Cristais de apo. filita transformados totalmente em quartzo. Típico fenômeno de pseudomorfose. 


JOSÉ MAGALHÃES LTDA. R u a s a r t a e o, 215 São PAULO - BRASIL 

